UNIVERSIDADE DE SÃO PAULO

ESCOLA DE ENFERMAGEM DE RIBEIRÃO PRETO

MARILENE RIVANY NUNES

REDE SOCIAL DE ADOLESCENTES EM LIBERDADE ASSISTIDA:

UM ESTUDO EXPLORATÓRIO 
MARILENE RIVANY NUNES

\section{REDE SOCIAL DE ADOLESCENTES EM LIBERDADE ASSISTIDA: UM ESTUDO EXPLORATÓRIO}

Tese apresentada à Escola de Enfermagem de Ribeirão Preto da Universidade de São Paulo, para obtenção do título de Doutor em Ciências, Programa de Pós-Graduação Enfermagem em Saúde Pública.

Linha de pesquisa: Assistência à criança e ao adolescente

Orientador: Profa. Dra. Marta Angélica Iossi Silva

\section{RIBEIRÃO PRETO}


Autorizo a reprodução e divulgação total ou parcial deste trabalho, por qualquer meio convencional ou eletrônico, para fins de estudo e pesquisa, desde que citada à fonte.

\section{FICHA CATALOGRÁFICA}

Nunes, Marilene Rivany

Rede social de adolescentes em liberdade assistida: um estudo exploratório. Ribeirão Preto, 2015.

p.140 p.: il. ; $30 \mathrm{~cm}$

Tese de Doutorado, apresentada à Escola de Enfermagem de Ribeirão Preto/USP. Área de concentração: Enfermagem em Saúde Pública.

Orientador: Marta Angélica Iossi Silva

1. adolescente . 2. crime. 3. rede social. 4. assistência à saúde 
NUNES, Marilene Rivany

Rede social de adolescentes em liberdade assistida: um estudo exploratório

Tese apresentada à Escola de Enfermagem de Ribeirão Preto da Universidade de São Paulo, para obtenção do título de Doutor em Ciências, Programa de Pós-Graduação Enfermagem em Saúde Pública.

Aprovado em / / /

Comissão Julgadora

Prof. Dra.

Instituição:

Prof. Dra.

Instituição:

Prof. Dra.

Instituição:

Prof. Dra.

Instituição:

Prof. Dra.

Instituição: 
Dedico esta tese à minha mãe, Elvira, e ao meu esposo, Jésus. 


\section{AGRADECIMENTOS}

Agradeço a Deus, pelo dom da vida e pela força espiritual para a realização desta tese.

Aos meus pais, José Antônio Nunes e Elvira Maria de Jesus, pelo apoio incondicional.

Ao meu marido, Jésus Ribeiro, pela paciência, pelo carinho, pela ajuda e pelas palavras de força e incentivo.

Aos meus filhos, Nikos, Kalil, Danty e ao meu enteado Leo, filho de coração, pelo apoio e incentivo constante.

À minha orientadora, Profa. Dra. Marta Angélica Iossi Silva, pela competência extraordinária como orientadora nesta trajetória. Sua compreensão, seriedade e, acima de tudo, tolerância e estímulo foram imprescindíveis para a construção desta tese.

Ao corpo docente e discente do Curso de Pós-Graduação Enfermagem em Saúde Pública da Escola de Enfermagem de Ribeirão Preto - USP, nível doutorado, pela oportunidade do aprendizado.

Às colegas Cleide e Isa, pelo apoio profissional e pela amizade. Minha eterna gratidão!

À funcionária do Programa de Pós-Graduação Enfermagem em Saúde Pública da EERP-USP, Shirley Figueiredo, pela ajuda constante.

Aos funcionários do CREAS Adan, Márcia, Dijorgiana, Marcelúcia e Maria Augusta que não mediram esforços para me apoiar na coleta de dados.

Ao Centro Universitário de Patos de Minas (UNIPAM) e a Secretaria Municipal de Saúde de Patos de Minas, pela oportunidade de construir esta tese.

Aos adolescentes em liberdade assistida, por sua disponibilidade em participar desta pesquisa. A todos que contribuíram, direta ou indiretamente, para a realização deste trabalho. 
Qualquer um pode julgar um crime tão bem quanto eu, mas o que eu quero é corrigir os motivos que levaram esse crime a ser cometido.

Confúcio (551 a.C/479 a.C) 


\section{RESUMO}

\section{NUNES, M.R. Rede social de adolescentes em liberdade assistida: um estudo exploratório. 140f. Tese (Doutorado). Escola de Enfermagem de Ribeirão Preto, Universidade de São Paulo, Ribeirão Preto, 2015.}

Este estudo teve por objetivo analisar os sentidos da rede social de adolescentes em Liberdade Assistida - LA no município de Patos de Minas, estado de Minas Gerais, buscando analisar as características estruturais, as funções e os atributos dos vínculos presentes em suas redes sociais. Partiu-se do pressuposto de que esses adolescentes possuem capacidade de perceber e elencar as características de sua rede social. Argumentou-se que uma rede social, com vínculos fortes, tem impacto no que diz respeito à conduta dos adolescentes, pois ela pode afastá-los ou mesmo impedir o engajamento com o ato infracional. Para isso, realizou-se um estudo exploratório, descritivo, de abordagem qualitativa. Participaram 26 adolescentes com idades de 13 a 18 anos, os quais estavam em cumprimento da medida socioeducativa LA no Centro de Referência Especializado de Assistência Social (CREAS), no referido município, durante os meses de janeiro a março de 2014, momento em que os dados foram coletados. Para a coleta dos dados, utilizou-se a entrevista semiestruturada e a construção de mapas de rede. Os dados foram analisados de acordo com os pressupostos do método de interpretação de sentidos. A partir da análise dos dados foram identificados quatro núcleos de sentido: 1) serviços e engajamento social; 2) membros da rede social, com destaque para figuras femininas; 3) essencialidade da rede social e 4) processo de adolescer e o cumprimento da LA. No conjunto, os dados das entrevistas e dos mapas revelaram ser significado o papel da família, com destaque da mãe, e do CREAS para o restabelecimento de um renovado convívio social dos adolescentes, possibilitando-lhes novos projetos de vida desvinculados de atos infracionais, como propõe a medida socioeducativa de LA. Todavia, os adolescentes não revelaram a existência de vínculos com profissionais de saúde. Dessa forma, pontuou-se, no trabalho, a necessidade de o enfermeiro, como profissional de destaque na atenção primária à saúde, atuar, junto a outros profissionais de saúde e educação, no sentido de fortalecer a rede social de adolescentes em conflito com a lei.

Palavras-chave: adolescente. crime. rede social. assistência à saúde 


\begin{abstract}
NUNES, M. R. Social Network of adolescents in probation: an exploratory study. 140 pages. [PhD dissertation]. São Paulo: Ribeirão Preto College of Nursing, University of São Paulo, Ribeirão Preto, 2015.

In this study we sought to analyze the meanings of social networks of adolescents in Probation in the city of Patos de Minas, Minas Gerais, aiming to understand the characteristics of the structure, functions and attributes of the ties in such networks. We used the assumption that adolescents in probation have the ability to perceive and rank the features of their social network, and argued that a social network with strong ties may impact their behavior, since it may drive them away from engagement with illegal acts. We then carried out an exploratory, descriptive, and qualitative study including 26 adolescents aged 13-18 years, who were in compliance with probation in Specialized Reference Center for Social Assistance (CREAS) in the aforementioned municipality during the months from January to March 2014, at which time data were collected through semi-structured interview and construction of network maps. Data were analyzed according to the interpretation of meanings method. From the data analysis, we identified four units of meaning: 1) services and social engagement; 2) members of the social network, especially female figures; 3) essentiality of the social network and 4) process of adolescence development and compliance with Probation. Taken together, the data revealed the importance of the family - especially the mother -, and CREAS for promoting adolescents' social life and a new life project without engagement with illegal acts. The adolescents, however, did not reveal the existence of ties with health professionals. In face of that, we highlighted the need for nurses, while prominent professionals in primary health care, to work together with other health and education professionals to strengthen the social network of adolescents engaged with illegal acts.
\end{abstract}

Keywords: adolescent. crime. social network. health care 


\section{RESUMEM}

NUNES, M.R. Red social de adolescentes en libertad vigilada: un estudio exploratorio. 140h. Tesis (Doctorado). Escuela de Enfermería de Ribeirão Preto, Universidad de Sao Paulo, Ribeirão Preto, 2015.

Esta tesis objetivó analizar el significado de la red social de adolescentes en Libertad Vigilada (LV) en el municipio de Patos de Minas, estado de Minas Gerais buscando analizar las características estructurales, de las funciones y de los atributos de los vínculos presentes en esas redes sociales. Se partió de la suposición de que esos adolescentes poseen capacidades de percibir y enumerar las características de su red social. Se argumentó que una red social, con vínculos fuertes, tiene impacto en sobre la conducta de los adolescentes, ya que ella puede alejarlos o inclusive impedir actos de infracción. Para eso, se realizó un estudio exploratorio, descriptivo, de abordaje cualitativo. Participaron 26 adolescentes con edades de 13 a 18 años, los cuales estaban cumpliendo la medida socioeducativa LV en el Centro de Referencia Especializado de Asistencia Social (CREAS), en el referido municipio, durante los meses de enero a marzo de 2014, momento en que los datos fueron recolectados. Para la recolección de los datos, se utilizó la entrevista semiestructurada y la construcción de mapas de las redes. Los datos fueron analizados de acuerdo con los presupuestos del método de interpretación de sentidos. A partir del análisis de los datos fueron identificados cuatro núcleos de sentido: 1) servicios y compromiso social; 2) miembros de la red social, con destaque para figuras femeninas; 3) esencia de la red social y 4) proceso en el período de la adolescencia y el cumplimiento de la LV. En su conjunto, los datos de las entrevistas y los mapas de la red revelaron que el papel de la familia es significativo, en el cual se destacan la madre y el CREAS, para el restablecimiento de una renovada convivencia social de los adolescentes, que da cabida a nuevos proyectos de vida, desvinculados de infracciones de la ley, como propone la medida socioeducativa de LV. Sin embargo, los adolescentes no revelaron la existencia de vínculos con profesionales de la salud. De esa forma, se destacó en esta tesis, la necesidad de que el enfermero, considerado como un profesional importante en la atención primaria de la salud, actúe conjuntamente con otros profesionales de la salud y educación, con la finalidad de fortalecer la red social de adolescentes en conflicto con la ley.

Palabras clave: Adolescente. Crimen. Red social. Asistencia a la salud. 


\section{LISTA DE TABELAS E QUADROS}

Tabela 1 - Perfil dos adolescentes em liberdade assistida. Patos de Minas, MG, Brasil, 2014. $(n=26)$.

Tabela 2 - Composição da rede social dos adolescentes em liberdade assistida, segundo as relações intimas, sociais e com conhecidos. Patos de Minas, MG, Brasil, 2014 .(n=26)

Tabela 3 - Número de adolescentes em liberdade assistida segundo os quadrantes e membros referidos nos mapas de redes sociais. Patos de Minas, MG, Brasil, 2014. $(n=26)$. 52

Tabela 4 - Frequência dos membros da rede social dos adolescentes em liberdade assistida enquanto relação intima na rede social. Patos de Minas, MG, Brasil, 2014. (n=26).

Tabela 5 - Frequência dos membros da rede social dos adolescentes em liberdade assistida enquanto relações sociais e com conhecidos na rede social. Patos de Minas, MG, Brasil, 2014. $(n=26)$.

Tabela 6 - Frequência dos membros com vínculos significativos na rede social dos adolescentes em liberdade assistida. Patos de Minas, MG, Brasil, 2014. ( $\mathrm{n}=26)$ .55

Tabela 7 - Frequência dos membros com vínculos fragilizados e rompidos na rede social dos adolescentes em liberdade assistida. Patos de Minas, MG, Brasil, 2014. $(n=26)$ 56

Quadro 1 - Membros da rede social dos adolescentes em liberdade assistida segundo o tipo de função exercida na rede social Patos de Minas, MG, Brasil, 2014. 


\section{LISTA DE FIGURAS}

Figura 1 - Mapa de violência do Estado de Minas Gerais (MINAS GERAIS, 2011).............18

Figura 2 - Modelo de mapa de rede social proposto por Sluzki (2010).................................36

Figura 3 - Mapa de rede social do adolescente em LA - Amizade, 13 anos.........................112

Figura 4 - Mapa de rede social do adolescente em LA - Aventura, 15 anos........................113

Figura 5 - Mapa de rede social do adolescente em LA - Branco, 17 anos..........................114

Figura 6 - Mapa de rede social do adolescente em LA - Branquinha, 16 anos...................115

Figura 7 - Mapa de rede social do adolescente em LA - Cachaça, 18 anos.........................116

Figura 8 - Mapa de rede social do adolescente em LA - Cantora, 16 anos..........................117

Figura 9 - Mapa de rede social do adolescente em LA - Companheiro, 17 anos.................118

Figura 10 - Mapa de rede social do adolescente em LA - Capoeira, 14 anos......................119

Figura 11 - Mapa de rede social do adolescente em LA - Dança,14 anos...........................120

Figura 12 - Mapa de rede social do adolescente em LA - Esporte, 16 anos.......................121

Figura 13 - Mapa de rede social do adolescente em LA - Festa, 17 anos............................122

Figura 14 - Mapa de rede social do adolescente - Futebol, 15 anos..................................123

Figura 15 - Mapa de rede social do adolescente em LA - Igreja, 18 anos..........................124

Figura 16 - Mapa de rede social do adolescente em LA - Lagoa, 14 anos..........................125

Figura 17 - Mapa de rede social do adolescente em LA - Lutador, 18 anos.........................126

Figura 18 - Mapa de rede social do adolescente em LA - Moda, 18 anos...........................127

Figura 19 - Mapa de rede social do adolescente em LA - Moreninha, 15 anos...................128

Figura 20 - Mapa de rede social do adolescente em LA - Moreno, 14 anos.........................129

Figura 21 - Mapa de rede social do adolescente em LA - Motorista, 17 anos.....................130

Figura 22 - Mapa de rede social do adolescente em LA - Namorador, 17 anos..................131

Figura 23 - Mapa de rede social do adolescente em LA - Prestativo, 15 anos.....................132

Figura 24 - Mapa de rede social do adolescente em LA - Piercing, 17 anos.......................133

Figura 25 - Mapa de rede social do adolescente em LA - Tean Sagon,17 anos..................134 
Figura 26 - Mapa de rede social do adolescente em LA - Tímido, 16 anos..........................135

Figura 27 - Mapa de rede social do adolescente em LA - Violão, 18 anos..........................136

Figura 28 - Mapa de rede social do adolescente em LA - Vergonhoso, 15 anos..................137 


\section{LISTA DE ABREVIATURAS}

CAAC

CEP

CEIP

CRAS

CREAS

ECA

EERP

ESF

IBGE

IDH

LA

NASF

OMS

ONG

PIA

PNAS

SIM

SINASE

SUAS

SUASE

UNICEF

USP
Certificado de Apresentação para Apreciação Ética

Comitê de ética e pesquisa

Centro de Internação Provisória

Centro de Referência de Assistência Social

Centro de Referência Especializado Assistência Social

Estatuto da Criança e do Adolescente

Escola de Enfermagem de Ribeirão Preto

Estratégia Saúde da Família

Instituto Brasileiro de Geografia e Estatística-IBGE

Índice de desenvolvimento humano

Liberdade Assistida

Núcleo de apoio à saúde da família

Organização Mundial de Saúde

Organização não governamental

Plano de atendimento individual

Política Nacional de Assistência Social

Sistema de Informações de Mortalidade

Sistema Nacional de Atendimento Socioeducativo

Sistema Único de Assistência Social

Subsecretária de Atendimento as Medidas Socioeducativas

Fundo das Nações Unidas para a Infância

Universidade de São Paulo 


\section{SUMÁRIO}

1 INTRODUÇÃO---- 16

1.1 A vulnerabilidade e a necessidade de uma rede protetora na adolescência ---------------- 19

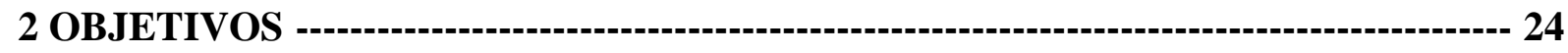

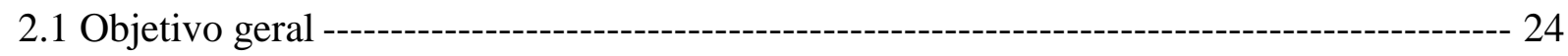

2.2 Objetivos específicos ------- 24

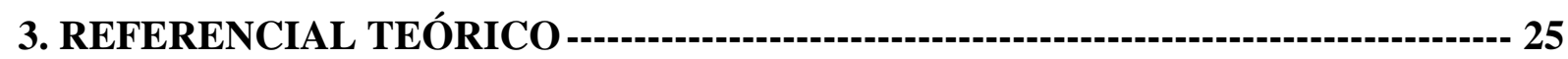

3.1 O contexto da adolescência e o profissional de enfermagem -------------------------------- 25

3.2 Adolescentes infratores e a medida protetiva de liberdade assistida------------------------- 29

3.3 Rede social: fator de proteção a adolescentes em liberdade assistida------------------------- 33

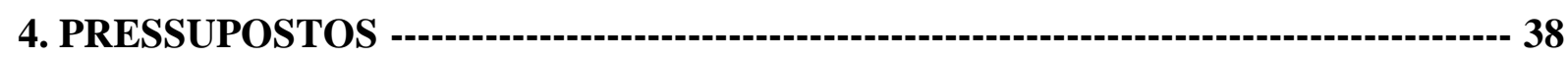

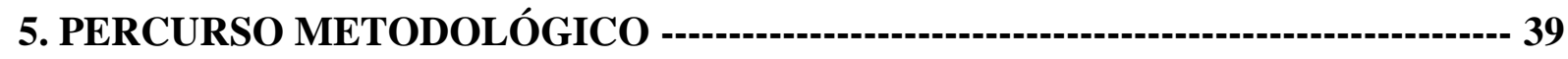

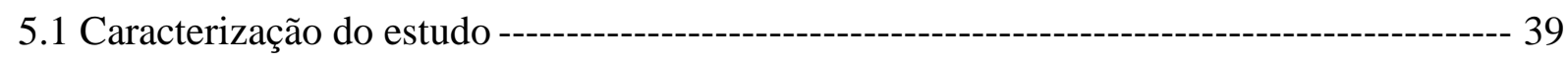

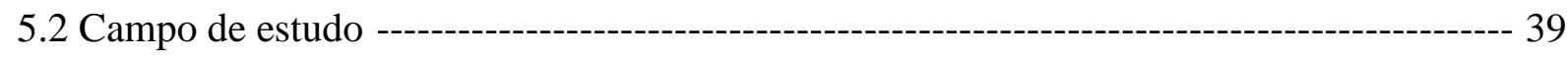

5.3 Participantes do estudo ------------------------------------------------------------------------------- 41

5.4 Instrumentos para coleta de dados --- 41

5.5 Procedimentos para coleta de dados ---------------------------------------------------------------- 45

5.6 Procedimentos para análise dos dados------------------------------------------------------- 46

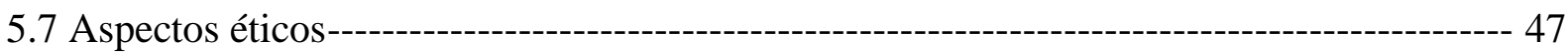

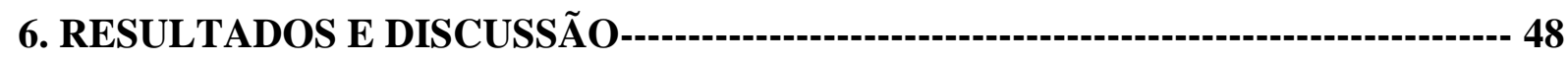

6.1 Perfil dos adolescentes participantes do estudo ------------------------------------------------- 48

6.2 A rede social dos adolescentes em liberdade assitida ------------------------------------------- 49

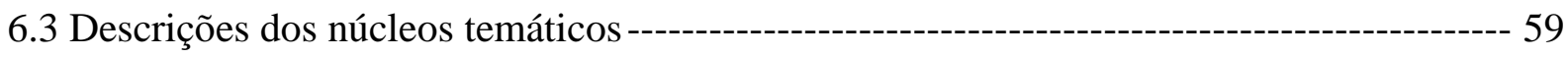

6.3.1 Serviços e engajamento social ------------------------------------------------------------------ 59

6.3.2 Membros da rede social: destaque para figuras femininas ------------------------------ 72

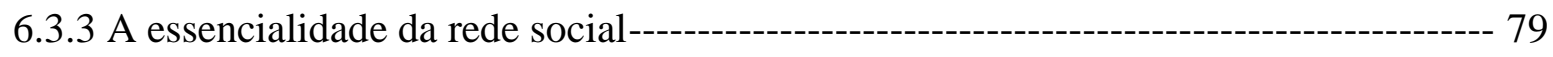


6.3.4 Processo de adolescer e o cumprimento da la

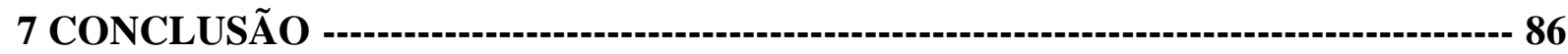

7.1 O perfil socioeconômico e demográfico dos adolescentes do estudo ------------------------ 86

7.2 Dimensões estruturais, funções e atributos dos vínculos nas redes sociais dos adolescentes

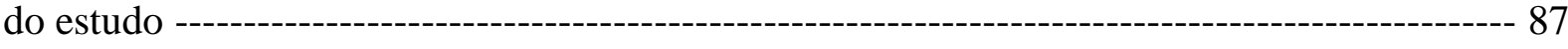

7.3 Sentidos atribuídos pelos adolescentes em la em relação a sua rede social---------------- 91

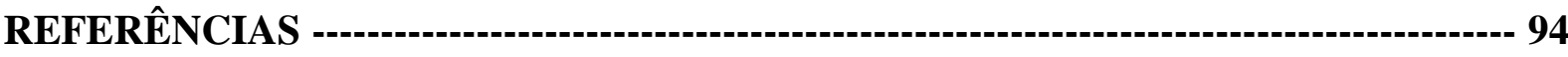

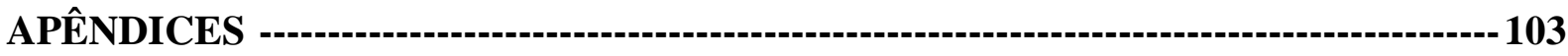

ANEXOS --138 


\section{INTRODUÇÃO}

Este estudo voltou-se para a escuta de adolescentes em conflito com a lei, os quais cumprem a medida socioeducativa Liberdade Assistida (LA), no município de Patos de Minas. O objetivo foi analisar os sentidos da rede social dos adolescentes em LA. Essa perspectiva foi adotada por se considerar imprescindível conhecer e situar o fenômeno da sócioeducação, após o cometimento do ato infracional, concretizado na medida LA na perspectiva da rede social e do suporte oferecido aos adolescentes que a vivenciam, a fim de construir olhares sobre essas situações e as possibilidades de enfrentamento, principalmente no que se refere à área da saúde.

Para a população adolescente e jovem do Brasil, dados relacionados a comportamentos de risco social, a exemplo do envolvimento em situações de violência e atos infracionais, chamam a atenção e compõem um perfil epidemiológico, o que evidencia uma maior vulnerabilidade individual, social, institucional e programática (CONTE, 2008).

Nesse sentido, o Mapa da Violência de 2014 registrou um aumento de homicídios a partir dos 13 anos de idade e um aumento significativo das taxas de suicídios a partir dos 17 ou 18 anos no Brasil. No conjunto dos dados, em 2012, a partir dos 19 anos de idade e até os 26 anos, as taxas de mortalidade violenta ultrapassaram os 100 óbitos por 100 mil jovens (WAISELFISZ, 2014). Esse estudo, de caráter epidemiológico, revelou, quantitativamente em uma série histórica, uma evolução da mortalidade violenta no Brasil, relacionada aos adolescentes e jovens, descrevendo o movimento de aumento das taxas de morte principalmente devido a causas violentas.

O estudo citado mostra ainda que no período de 1980 a 2012, identificou-se, entre os jovens, que $62,9 \%$ das mortes eram provocadas por causas externas, enquanto que na população adulta, esse percentual foi de apenas $8,1 \%$. Já no que diz respeito a óbitos em virtude de homicídios, o estudo mostra que entre os jovens os homicídios foram responsáveis por $28,8 \%$ das mortes acontecidas no período estudado, ao passo que na população adulta esse percentual representa tão somente $2 \%$ (WAISELFISZ, 2014).

A Organização Mundial de Saúde (Organização Mundial de Saúde, 2014), trabalhando também com dados de 2012, constatou que 1,3 milhão de adolescentes morreram naquele ano; porém, houve uma redução na taxa quando comparado aos anos 2000, em que 1,5 milhão de adolescentes morreram. Em 2012 as principais causas de morte identificadas 
pela OMS foram: lesão por acidentes de trânsito, HIV, suicídio, infecções respiratórias e violência interpessoal. A conclusão do relatório, que traz subsídios para se compreender a violência enquanto fenômeno social global indica que algumas questões ainda são negligenciadas na abordagem da saúde do adolescente, como os índices de suicídio, o uso de álcool e outras drogas e as situações de violência interpessoal.

Uma pesquisa transversal analítica desenvolvida na tríplice fronteira BrasilParaguai-Argentina mostrou que a violência entre os adolescentes se caracterizava em interpessoal, coletiva e autoinfligida. Entre os motivos para se praticar atos de violência, estava o uso de bebidas alcoólicas e drogas. O estudo constatou que os adolescentes do Brasil, da Argentina e do Paraguai são vítimas e também vítimas-agressoras, confirmando um ciclo de violência. $\mathrm{O}$ estudo concluiu, assim, que a violência entre adolescentes é uma realidade presente nos três países investigados e que são necessárias ações inter-setoriais de enfrentamento, com a necessidade de envolvimento familiar e político (PRIOTO, 2013).

É nesse cenário epidemiológico que se problematiza a questão do ato infracional na adolescência e a resposta do Estado para ele (a Liberdade Assistida). No Brasil, país marcado por desigualdades sociais, dados do Censo do Sistema Único de Assistencial Social (SUAS) e do Centro de Referência Especializado em Assistência Social (CREAS) revelaram que no ano de 2010 havia 67.045 adolescentes que cometeram atos infracionais em cumprimento de medida socioeducativa em todo o território nacional. Deste total, 58.661 eram do sexo masculino e 8.384 feminino, 35.066 adolescentes estavam em cumprimento da medida LA, sendo que neste grupo a prevalência de 31.319 adolescentes era do sexo masculino (BRASIL, 2011).

O Estado de Minas elaborou um mapeamento dos municípios onde há mais violência no meio escolar (MINAS GERAIS, 2011). Isso foi feito pelo cruzamento das ocorrências da Polícia Militar, registradas dentro e nos arredores de instituições das redes particular, municipal, estadual e federal em 2011, com o número de estudantes de cada cidade, segundo dados oficiais do Censo Escolar, elaborado pelo Ministério da Educação.

Naquele ano, foram registradas 1.363 ocorrências nas escolas desses 29 municípios, um número 3,9\% menor do que no ano anterior, quando houve 1.417. A Polícia Militar computou, ainda, 280 crimes violentos contra estudantes, professores e funcionários. Foram 127 registros de agressões, 72 de lesões corporais, 15 de roubos, três estupros e atentados violentos ao pudor, um assédio sexual, um homicídio e 61 que constaram como "outras infrações contra a pessoa". Os furtos foram às ocorrências que mais apareceram nas instituições de ensino mineiras, com 393 registros, correspondendo a $29 \%$ do volume total das 
ocorrências registradas em 2011. Em Patos de Minas, em 2011, das 86 ocorrências registradas, 15 foram furtos (17\%), que nessa cidade praticamente se igualam aos 14 (16\%) registros de lesão corporal.

Ainda de acordo com esse levantamento, Patos de Minas ganhou a primeira posição entre as 29 cidades com mais de 100 mil habitantes do estado, no que tange ao número de ocorrências de crimes cometidos por alunos no contexto da escola: foram 267,2 ocorrências para cada grupo de 100 mil estudantes. Esse índice foi $48 \%$ maior do que o segundo lugar no ranking, ocupado por Juiz de Fora, na Zona da Mata, com 180,4 ocorrências por grupo de 100 mil alunos (Figura 1).

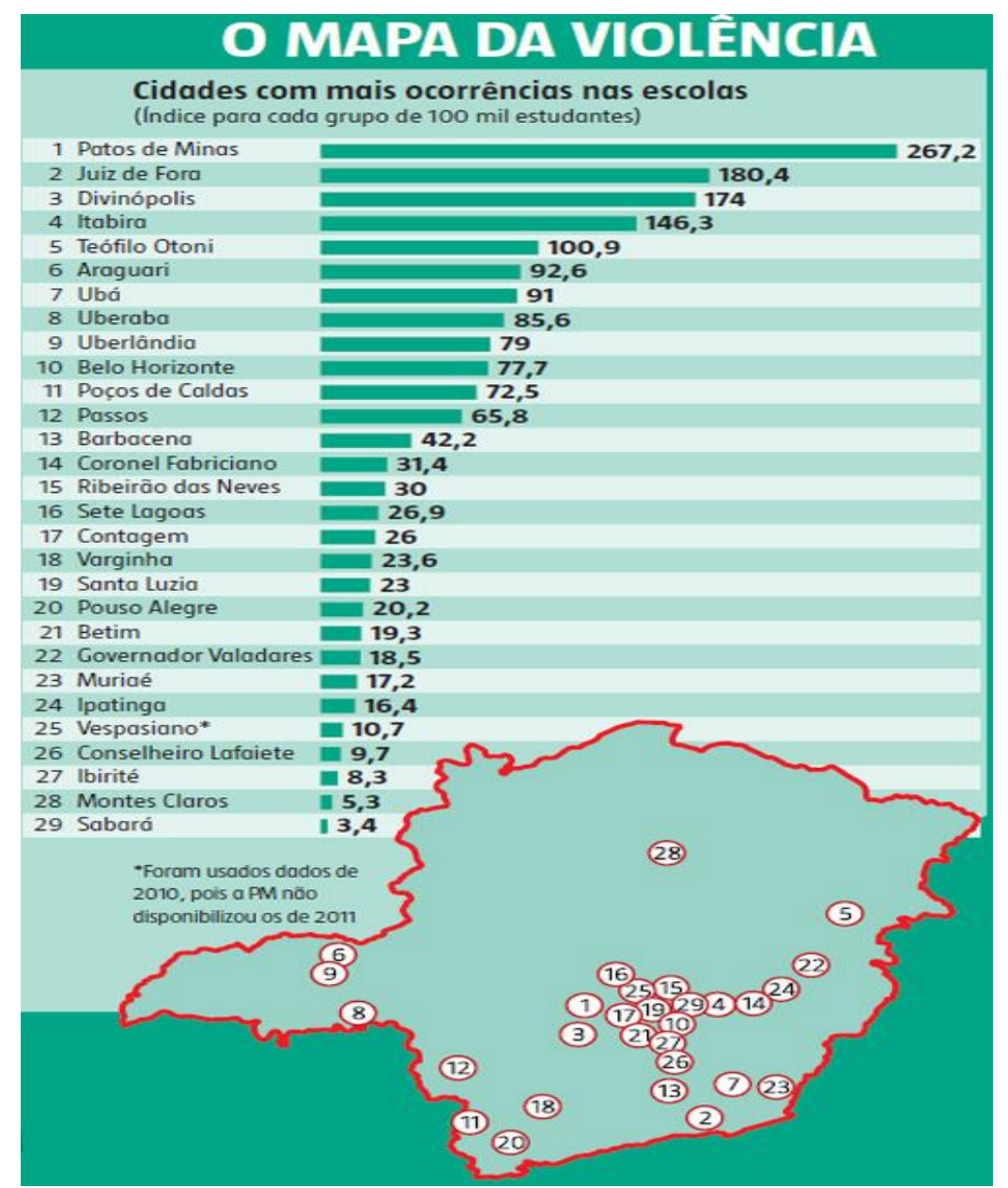

Figura 1- Mapa da violência do Estado de Minas Gerais ( MINAS GERAIS, 2011)

Segundo documentos obtidos no Centro de Internação Provisória de Patos de Minas (CEIP), no período de novembro de 2012 a agosto de 2014, a instituição recebeu 168 adolescentes para cumprimento da medida de internação provisória. O destaque das 
informações está na taxa de reincidências, numa frequência de 44 adolescentes, neste período (CENTRO DE INTERNAÇÃO PROVISÓRIA DE PATOS DE MINAS, 2014).

Já o CREAS, de Patos de Minas, descreve em sua planilha trimestral de monitoramento de acompanhamento dos adolescentes em LA (abril, maio e junho/2014), a existência de acompanhamento de 107 adolescentes, sendo 101 (94,4\%) cumprindo a medida LA e seis $(5,6 \%)$ a medida de Prestação de Serviço a Comunidade (PSC). Em relação ao tipo de ato infracional mais cometido, prevaleceu furto, uso de droga, posse ou porte ilegal de armas, tráfico de drogas, lesão corporal, receptação e roubo a mão armada, entre outros (CENTRO DE REFERÊNCIA ESPECIALIZADO DE ASSISTÊNCIA SOCIAL, 2014). As idades dos adolescentes variaram de 13 a 19 anos, sendo 2\% de 13 anos, 9\% de 14 anos, 19\% de 15 anos, 24\% de 16 anos, $1 \%$ de 17 anos, $11 \%$ de 18 anos e 34\% de 19 anos (CENTRO DE REFERÊNCIA ESPECIALIZADO DE ASSISTÊNCIA SOCIAL, 2014).

Segundo Davoglio e Gauer (2011), a literatura tem apresentado aspectos que buscam responder o porquê do envolvimento dos adolescentes com atos infracionais. Para esses estudiosos, vários fatores de risco e de vulnerabilidades, vivenciados pelos adolescentes, podem remetê-los a uma crise nos seus vínculos tanto sociais como familiares, fragilizando as relações com a rede social e contribuindo, assim, para o surgimento da conduta infracional. Esses aspectos são focalizados a seguir.

\subsection{A VULNERABILIDADE E A NECESSIDADE DE UMA REDE PROTETORA NA ADOLESCÊNCIA}

A adolescência é entendida como um momento especialmente crítico para o desenvolvimento da conduta infracional. $\mathrm{Na}$ área da Criminologia Desenvolvimental, estudos indicam que esse momento é marcado por comportamentos socialmente divergentes e a violação da lei aparece como parte de um processo estatisticamente normativo, o que pode refletir nas taxas de envolvimento dos adolescentes em atos infracionais (BARBERET et al., 2004; LE BLANC, 2006).

Entre os fatores apontados como responsáveis pelo envolvimento do adolescente no ato infracional destacam-se: a fraca vinculação dos adolescentes com seus pais ou responsáveis, problemas na comunicação, pouco diálogo, supervisão parenteral insuficiente (BUI, 2009; ZAPPE; DIAS, 2012). No contexto escolar destaca-se a experiência escolar negativa como o baixo desempenho, dificuldade na comunicação e interação com os pares e professores e repetidas punições ou sanções escolares (DESTRO; SOUZA, 2012). Afora isso, 
tem-se a elevada vulnerabilidade individual, social, institucional e programática; as situações de negligência e abandono; a pobreza, a exclusão social, a criminalidade e violência na família, na escola, na comunidade e na sociedade em geral; o abuso de substâncias psicoativas, o abandono da escola, a ausência de supervisão efetiva de adultos responsáveis e de cuidadores e a falta de oportunidade de trabalho (ARANZEDO; SOUZA, 2007; CARMO et al., 2011).

Nesse cenário, o adolescente, quando em conflito com a lei, é considerado um sujeito exposto a diversas situações de vulnerabilidade definidas como aspectos que se constituem em dificuldades e problemas individuais, que podem influenciar o aparecimento de outros eventos estressores e fatores que vulnerabilizam. Bertolozzi et al. (2009) relatam que a vulnerabilidade traz elementos abstratos associados e associáveis aos processos de adoecimento e/ou a eventos estressores para planos de elaboração teórica mais concreto e particularizado, em que os nexos e mediações entre esses processos sejam o objeto de conhecimento. Nesta linha, o conceito de vulnerabilidade inclui a detecção das fragilidades, mas também a capacidade de enfrentamento dos problemas/ agravos de saúde/ eventos estressores como a vivência do adolescente com o envolvimento com o ato infracional.

Assim, os adolescentes em situação de vulnerabilidade são aqueles que não conseguem oferecer respostas positivas ou saudáveis para os problemas do cotidiano, seja no nível individual, social ou em termos programáticos e de políticas públicas (DE ANTONI; KOLLER, 2000; BRANCO; WAGNER; DEMARCHI, 2008; FONSECA et al., 2013).

Segundo Souza (2010) existem também fatores eminentemente subjetivos e pessoais que podem justificar a conduta infracional. Nesse sentido, Silveira (2009) aponta fatores intrínsecos (biológicos, genéticos, psicológicos e emocionais) e extrínsecos (a família, os amigos, a televisão, a escola, os grupos sociais e a comunidade). Davoglio; Gauer (2011) descreveram que algumas características biológicas e psicológicas também têm sido apontadas como fator de risco nesta direção, tais como ser jovem do sexo masculino, ter problemas escolares, danos neurológicos sutis, impulsividade, hiperatividade, precário controle diante de frustrações, deficiência de atenção e incapacidade de planejamento e fixação de metas, baixos níveis de inteligência entre outros. Nessa perspectiva, um estudo realizado por Watts; McNulty (2015) mostra que elementos genéticos podem desencadear o envolvimento de adolescentes em grupos que apresentam comportamento antissocial e cometem atos infracionais.

Nessa mesma perspectiva, um relatório publicado pelo Fundo das Nações Unidas para a Infância (FUNDO DAS NAÇÕES UNIDAS PARA A INFÂNCIA, 2011) mostra que 
os adolescentes em conflito com a lei, de maneira geral, são oriundos de famílias de baixa renda, com acesso reduzido a políticas públicas essenciais, como a educação e a saúde. Além disso, tiveram alguma experiência relacionada ao uso de drogas. Em outras palavras, "são meninos e meninas com uma história de exclusão social e negação de direitos" (FUNDO DAS NAÇÕES UNIDAS PARA A INFÂNCIA, 2011, p. 103). Fica claro que as vulnerabilidades vivenciadas pelos adolescentes e que podem determinar o envolvimento em atos infracionais podem ser assim resumidas: viver na pobreza, o nível precário de escolaridade, a exploração no trabalho, à privação da convivência familiar e comunitária, os homicídios, a gravidez na adolescência, as doenças sexualmente transmissíveis, o abuso e a exploração sexual e o abuso de drogas.

Considerando essas perspectivas, a vulnerabilidade na adolescência e a condição de adolescente em conflito com a lei e em cumprimento da medida socioeducativa LA, Davim et al. (2009) e Carmo et al. (2011) pontuam a importância de rede social fortemente articulada, com bons vínculos e grande diversidade de membros como fator de proteção, incluindo aqui os serviços de saúde, educação e também da assistência social. Assim, a rede social não é composta somente pela família, em termos de cuidado e atenção, mas também pela comunidade, sociedade e Estado. Esse tipo de rede, segundo os autores, garante aos adolescentes condições para enfrentarem e superarem adversidades, bem como não se envolverem em situações que possam lhes causar danos e agravos, incluindo o comportamento infracional. Ademais, a rede pode contribuir para o não envolvimento e até mesmo a desistência do ato infracional.

Nessa linha de pensamento, a rede social pode propiciar ao adolescente uma nova visão de mundo que ultrapassa o nível da criminalidade, oferecendo-lhe real possibilidade de mudança por meio da educação, da profissionalização e da esperança de um novo projeto de vida e consequentemente de um futuro melhor, não relacionado a novas infrações (COSTA; ASSIS, 2006; WESTRUPP, 2010).

Considerando que uma das proposições da LA é garantir direitos aos adolescentes em termos de reinserção na família e na sociedade com vistas a prevenir novos envolvimentos e mais conflitos com a lei, ou mesmo a recidiva no sistema socioeducativo, observa-se que essa medida está centrada na lógica do cuidado integral aos adolescentes, pois prevê a responsabilização do adolescente diante do ato infracional e sua integração social baseada na construção de planos individuais de atenção intersetorial. Na educação, por exemplo, deve haver um plano individual de cuidado ao adolescente em LA, assim como na proteção social e na saúde. 
Especificadamente na área da saúde, no âmbito da atenção primária, a ferramenta projeto terapêtico singular visa a ações a partir da perspectiva e das necessidades do adolescente e a construção de projetos de vida que ultrapassem a abordagem do ato infracional. Nesse nível da atenção também se pode favorecer a capacitação das famílias, para que auxiliem no processo de reinserção social, oferecendo suporte comunitário e emocional, o que previne novas práticas de crime, bem como promove a saúde e o desenvolvimento de sujeitos e grupos (GIACOMOZZII; LACERDA, 2006; KANTORSKI et al., 2010).

Neste sentido, destaca-se que o profissional de enfermagem, atuante na atenção primária à saúde e na Estratégia Saúde da Família (ESF), pode contribuir na elaboração de projetos terapêuticos singulares aos adolescentes em LA e, a partir de evidências cientificas, atuar no sentido de fortalecer a rede social dos adolescentes em conflito com a lei, especialmente entre eles, sua família e sua comunidade.

Uma opção metodológica para trabalhar com a concepção de rede social é a proposta de Sluzki (2006, 2010), que define rede social como um sistema de interação formado por sujeitos que se ajudam e se apoiam. É uma organização de interações no nicho individual e considerada significativa para os sujeitos. Nela se desenham as relações de vínculo e suas funções na rede social, que favorece o bem-estar, a saúde e a qualidade de vida dos sujeitos. A partir da representação gráfica da rede social de um sujeito, é possível identificar as funções dos vínculos, ou seja, a companhia social, o apoio emocional, o guia cognitivo e de conselhos, a regulação e o controle social, a ajuda material e o acesso a novos contatos, por exemplo, que dão suporte para enfrentar situações difíceis ou mesmo auxiliar no processo de desenvolvimento e na saúde.

Nesse sentido, Nunes et al., (2010); Ferreira et al., (2012) sugere investir em estudos de identificação da percepção de apoios, como recurso essencial para o fornecimento de elementos que possibilitem elaborar um plano flexível e dinâmico de intervenções em famílias e auxiliar na definição de políticas públicas voltadas à promoção de saúde.

Diante do exposto e da constatação de que existem poucas investigações que se debruçam sobre o tema, especialmente no que tange ao mapeamento da rede social de adolescentes em LA, e nas áreas da Enfermagem e da Saúde, esta tese se justifica por considerar a importância do contexto de vulnerabilidade em que possam se encontrar os adolescentes em LA e a necessidade de uma rede social fortemente estabelecida para a proteção dos adolescentes.

Essa abordagem pode propiciar uma nova compreensão dos fatores de proteção que possam ser oferecidos aos adolescentes em conflito com a lei, construindo evidências e 
conhecimentos científicos que possam, também, orientar ações na esfera da saúde coletiva e no que diz respeito à construção de redes sociais aos adolescentes em LA.

Além disso, compreender as redes sociais desses sujeitos pode contribuir para o fortalecimento da rede social desses adolescentes e a resolução de diferentes problemas sociais, ajudando esses adolescentes no processo de reinserção social e de superação do momento problemático vivido, além de subsidiar os profissionais da educação, da assistência social e prioritariamente da saúde, tanto no núcleo quanto no campo de sua atuação.

O trabalho foi estruturado da seguinte forma: primeiramente serão apresentados os objetivos, em seguida os aspectos teóricos e conceituais sobre adolescência, a medida protetiva de LA e o referencial teórico adotado da rede social de Sluzki. Na sequência são descritos os pressupostos e apresentado o percurso metodológico adotado. No capítulo Resultados e Discussões estão sintetizados os achados da pesquisa e sua discussão a partir da literatura científica. E por fim, na conclusão são revistos e concluídos os objetivos do trabalho, bem como evidenciado as principais contribuições desta tese, suas lacunas e dificuldades. 


\section{OBJETIVOS}

\subsection{OBJETIVO GERAL}

- Analisar os sentidos da rede social de adolescentes em LA no município de Patos de Minas, estado de Minas Gerais.

\subsection{OBJETIVOS ESPECÍFICOS}

- Conhecer o perfil socioeconômico e demográfico desses adolescentes.

- Analisar as características estruturais, as funções e os atributos dos vínculos presentes nas redes sociais desses adolescentes. 


\section{REFERENCIAL TEÓRICO}

\subsection{O CONTEXTO DA ADOLESCÊNCIA E O PROFISSIONAL DE ENFERMAGEM}

A adolescência é um importante momento do desenvolvimento humano, caracterizado pela transição da infância para a idade adulta e por mudanças biológicas. $\mathrm{O}$ Estatuto da Criança e do Adolescente $(E C A)^{1}$ define adolescência como o período da vida humana que compreende a faixa etária de 12 a 18 anos (BRASIL, 2010). Esse critério etário é também adotado pela OMS e pelo Ministério da Saúde do Brasil, que consideram a adolescência como o período compreendido entre os 10 e os 19 anos. Por sua vez, o Instituto Brasileiro de Geografia e Estatística (IBGE) utiliza a categoria de jovem, considerando-se a idade que vai desde o nascimento até os 19 anos de idade. Nesta tese adota-se a proposta de classificação sugerida pelo ECA.

Ainda nesse sentido, Silva (2012) também define a adolescência como um período biopsicossocial caracterizado pela transição da infância para a fase adulta, envolvendo transformações físicas, mentais, sexuais e sociais. Outros estudiosos (FERNANDES; FERREIRA; CABRAL, 2011; SCHOEN-FERREIRA; AZNAR-FARIAS; SILVARES, 2010; SILVA et al., 2014), acrescentam que esse período significa não apenas a preparação para a vida adulta, mas um estágio do ciclo vital com sentidos e significados socialmente construídos.

Esse é um momento de grandes e profundas transformações em que se instalam conflitos psíquicos e de crise existencial, que contrastam com as vivências da infância. Esse momento do desenvolvimento exige uma adequação e integração ao mundo social de forma mais intensa, muitas vezes mediada pela inserção no mercado de trabalho, por exemplo, e na relação com os colegas, o que é complexo, pois coloca o adolescente diante de questões que são do domínio ético e social, colocando em xeque sua inserção ativa na sociedade como um todo (GUERRA et al., 2010). Nessa linha de pensamento, Brêtas (2010, p. 92) pontua que “(...) não devemos apenas falar da adolescência, mas, das adolescências, que são definidas por aquilo que está ao entorno, pelos contextos sócioculturais, pela sua realidade, situando-as em seu tempo, em sua cultura".

\footnotetext{
${ }^{1}$ Criado pela Lei 8.069, de 1990, utilizamos a publicação do Ministério da Justiça. Estatuto da Criança e do Adolescente. Lei no 8069 de 13 julho de 1990. Brasília, Brasil.80 p. 2010.
} 
Nesta fase, o corpo é um importante elemento de identificação. Surgem as preocupações com a beleza, principalmente aquela imposta pela mídia, e com a aquisição de bens e produtos, fortemente estimulada pela sociedade capitalista (SCHOEN-FERREIRA; AZNAR-FARIAS; SILVARES, 2010). Para esses autores, esses movimentos dos adolescentes passam por aspectos de idealização de uma maneira mais conectada de estar na sociedade, compartilhando não apenas dos valores vigentes, mas também chamando a atenção para si como sujeitos que podem estar adequadamente inseridos de acordo com aquilo que os demais esperam deles.

As transformações nos adolescentes ocorrem simultaneamente gerando comportamentos e emoções não antes sentidas, que podem gerar incompreensão por aqueles que compõem seu círculo de convivência (DAVIM et al., 2009). Várias teorias de diferentes áreas tentaram explicar o porquê de essas transformações significarem grandes dificuldades para o momento vivido. Algumas buscam localizar no adolescente os conflitos, as inseguranças, os anseios; outras tentam ampliar o olhar buscando referências no contexto e no desenvolvimento das sociedades e das relações como fortes contribuintes para o processo de desenvolvimento dos adolescentes (EISENSTEIN, 2005; ALMEIDA; RODRIGUES; SIMÕES, 2007; AMPARO et al., 2008; BITENCOURT et al., 2013).

Tendo como referencial teórico a sociologia, o processo adolescer é considerado histórico, social e cultural, congregando aspectos biológicos relacionados à puberdade, mas não se encerrando nesses aspectos. Essa forma de entendimento parte do pressuposto de que não há como dissociar os sujeitos da sociedade e seus movimentos de organização e estruturação.

Assim sendo, no decorrer da adolescência, segundo Campos (2010), o sujeito está vulnerável não só aos efeitos decorrentes das transformações biológicas, mas há também uma mudança significativa na maneira como se relaciona com o mundo e como os ambientes familiares, escolares e comunitários. Por exemplo, é nessa fase que ocorre a valorização excessiva do grupo de pares, da busca por parceiros sexuais e vinculações diferentes daquelas mantidas na infância, estritamente voltadas para o contexto familiar. É a inserção da pessoa na sociedade em um contexto mais amplo. Essa relação com o grupo de pares é essencial inclusive na análise de sua rede social, pois esse grupo deve aparecer como importante elemento que oferece diferentes tipos de apoio (SCHNEIDER; RAMIRES, 2007; COCCO; LOPES, 2010).

Dessa forma, os adolescentes experienciam um período de vulnerabilidade, seja individual, social ou programática (AYRES, 2006). Assim, eles podem se envolver em 
comportamentos contrários a ordem social vigente. Isso envolve, a exemplo, o uso de álcool e drogas, conflitos familiares e sociais, práticas de atos infracionais, entre outros.

Nos últimos anos, a noção de vulnerabilidade dos adolescentes vem sendo cada vez mais explorada, indicando maneiras diferentes de se compreender este importante momento do ciclo vital. Além das perspectivas das teorias de desenvolvimento, esse momento é também focalizado em perspectivas acadêmicas nas áreas da saúde, da educação e do serviço social.

Nessa direção, a enfermagem, enquanto área da atenção à saúde e prática social, se ocupa de aspectos relacionados à vulnerabilidade dos adolescentes e tem se dedicado a questões específicas como a sua saúde reprodutiva, gravidez, processos e estratégias de cuidado (OLIVEIRA; CARVALHO; SILVA, 2008; OLIVEIRA et al., 2009).

Questões da formação do enfermeiro, como a inserção dessa temática nos currículos e como eles devem ser abordados nos serviços são algumas das questões apontadas como fundamentais para se pensar a efetivação do cuidado integral e o atendimento às necessidades do adolescente (HIGARASHI et al., 2011). Segundo esses autores, a principal dificuldade na atenção aos adolescentes se relaciona à captação/adesão dos mesmos nas atividades propostas pelas equipes de saúde da família, visto que os adolescentes raramente procuram esse serviço.

Além disso, o estudo destaca a necessidade de formação específica do profissional de enfermagem e de trabalho em equipe multiprofissional para trabalhar com esse público.

Voltando a atenção para o adolescente que comete a prática abusiva de uso de álcool, um estudo concluiu que a enfermagem pode executar ações diretas e prioritárias em relação a esses sujeitos (D’ANDREA; VENTURA; COSTA JUNIOR, 2014). Segundo esse estudo, considerando que o consumo de álcool pode ser típico do grupo a que os adolescentes pertencem, os enfermeiros são fundamentais na coordenação de esforços dentro de qualquer discussão em termos de políticas para enfrentar a questão do envolvimento do adolescente com essa prática de uso de álcool que traz prejuízos para a saúde e riscos para si mesmos e a sociedade (D'ANDREA; VENTURA; COSTA JUNIOR, 2014).

Ressalta-se que enfermeiro pode desempenhar um papel essencial na prevenção do uso de drogas. Entretanto, o tema precisa ser trabalhado durante a formação profissional (CORRADI-WEBSTER; ESPER; PILLON, 2009). Além disso, de acordo com esses autores, é preciso que o profissional de enfermagem desenvolva habilidades de escuta qualificada e busque subsidiar suas práticas a partir das histórias e experiências que os próprios 
adolescentes trazem, sendo necessário, para isso, construir estratégias diferenciadas e contextuais para abordar o tema.

Monteiro et al. (2011), por sua vez, investigaram ações socioeducativas oferecidas por enfermeiros a adolescentes em conflito com a lei em regime de semiliberdade. Os autores concluíram que as medidas socioeducativas são ferramentas essenciais no cuidado ao adolescente em conflito com a lei, pois extrapola as limitações impostas pelas medidas de privação de liberdade e garante o restabelecimento do convívio e das relações sociais. Os autores pontuam, ainda, a necessidade de o enfermeiro agregar, ao seu fazer cotidiano, estratégias e práticas comprometidas com a promoção à saúde do adolescente sob medida socioeducativa. Neste estudo, evidencia a necessidade de pensar o cuidado da saúde do adolescente envolvido com atos infracionais como algo amplo e contextual.

Em face das questões arroladas acima, Davim et al. (2009) e Carmo et al. (2011) pontuam a necessidade de o adolescente ser amparado por uma rede protetora, composta não apenas da família, mas da comunidade, da sociedade e do Estado. Essa rede, segundo os autores, propicia a ele condições de enfrentamento e superação de adversidades, bem como seu não envolvimento em situações que possam lhe causar danos e agravos, incluindo conflitos com a lei, isto é, o comportamento infracional. Essas condições são elencadas pelo ECA como "efetivação dos direitos referentes à vida, à saúde, à alimentação, à educação, ao esporte, ao lazer, à profissionalização, à cultura, à dignidade, ao respeito, à liberdade, à convivência familiar e comunitária" (BRASIL, 2010, Art. 4º p.31).

Muitas vezes o problema do adolescente é estar inserido num ambiente desfavorável econômica, cultural ou emocionalmente, ou ainda em situações de vulnerabilidade como insuficiência de políticas públicas em saúde e educação, relações de gênero, cruzadas com raça/etnia e classe social, condições de vida, condições de saúde, acesso ou não a informações, entre outros. Nesses casos, necessitam de uma ampla rede social para ressignificarem esses aspectos que são relacionados às condições de vulnerabilidade e a que são expostos. A ausência dessa rede pode colaborar para que o adolescente pratique atos infracionais, embora se saiba que o ato infracional surge do resultado negativo de uma somatória de fatores complexos e multifacetados. Em face do exposto, a abordagem dos problemas mais comuns da adolescência se torna delicado e necessário, principalmente considerando as questões relativas à rede social que se interfaceiam com as questões contextuais dos adolescentes.

Para Banaco (2011), os comportamentos são multideterminados e podem ter também várias funções diferentes em cada ambiente. Assim, a investigação de 
comportamentos problemáticos de adolescentes sem considerar devidamente seu contexto social pode se tornar incompleta e muitas vezes incorreta. Esta é uma das justificativas para que sejam desenvolvidos estudos que investiguem como as redes sociais de adolescentes em LA se constroem e como elas podem ser essenciais para que não haja práticas de comportamentos de atos infracionais.

Antes de adentrar a questão das redes sociais de adolescentes, propriamente ditas, enfoca-se, na seção seguinte, a questão da medida socioeducativa LA.

\subsection{ADOLESCENTES INFRATORES E A MEDIDA PROTETIVA DE LIBERDADE ASSISTIDA}

Para Morais (2012), a manifestação de conflitos ou práticas problemáticas apresentadas por adolescentes devem ser interpretadas como comportamentos em associação com a relação que eles estabelecem com o mundo. Assim sendo, é a partir do entendimento dessa relação que devemos buscar as causas do ato infracional, ampliando a abordagem sobre as perspectivas meramente individuias, inclusive nos modelos de atenção e proteção. De acordo com o referido autor, redes sociais fragilizadas são fatores que podem levar os adolescentes ao ato infracional.

Neste sentido, a história social da adolescência no Brasil e como os adolescentes foram sendo concebidos ao longo do tempo, passando de "menores" em condição irregular na sociedade para sujeitos de direitos e de prioridade, aponta uma perspectiva e um novo paradigma de como devemos lidar com a prática de atos infracionais neste momento do desenvolvimento. Pinheiro (2006) sintetiza que no Brasil, até o início dos anos 1990, a infância e a adolescência eram objetos de controle, disciplina e repressão social, sendo muito fortes as ideias de que esses grupos, quando em situações de vulnerabilidade, deveriam ser institucionalizados para garantir o controle. Com o ECA, a autora aborda que esses períodos do desenvolvimento ganharam outros contornos e crianças e adolescentes passaram a ser entendidos como sujeitos de direitos.

$\mathrm{Na}$ lógica legal, o ECA incorporou novos significados ao lugar que a criança e o adolescente possuíam na sociedade brasileira, trazendo a concepção de que novos tratamentos às demandas desses sujeitos deveriam ser oferecidos, rompendo com a tradição histórica de tutela e foco na institucionalização (SOUSA; ALMEIDA, 2011).

Ainda no campo do direito, houve uma ruptura com a Doutrina de Situação Irregular, que fundamentava os históricos Códigos de Menores (1927 e 1979), responsáveis 
por punir e normatizar a situação da infância e da adolescência no Brasil. Essa mudança significou a proposição da Doutrina de Proteção Integral, em que o "menor" passou de objeto assujeitado do processo jurídico, quando em situação de risco, vulnerabilidade ou violação de direitos, para uma nova categoria de sujeito do processo jurídico e do seu processo de vida, observando-se direitos e deveres como a condição especial de desenvolvimento (SARAIVA, 2009).

Nesse sentido, quando o adolescente entra em conflito com a lei, cometendo atos infracionários, ele está sujeito a penalidades das medidas socioeducativas prescritas pelo ECA em seu artigo112, com destaque para LA. Em um resgate histórico Brito; Koller (2007) afirma que:

\begin{abstract}
Com a promulgação do Estatuto da Criança e do Adolescente em 1990, novos parâmetros para o atendimento de crianças e adolescentes se fazem necessários seguindo-se, agora, indicação da doutrina de proteção integral. [... ] Seguindo essa lógica, observa-se em uma proposta atual de execução de liberdade assistida, a necessidade de se romper com práticas e procedimentos comumente utilizados nos antigos serviços de LA, desconstruindo-se referenciais vigentes por ocasião da doutrina da situação irregular, base do Código de 1979. Se a doutrina de proteção integral altera a compreensão sobre as políticas que devem ser priorizadas no atendimento à parcela infanto-juvenil de nossa sociedade, deve modificar também, em sua essência, a execução das medidas socioeducativas. [...] Compreende-se, portanto, que a liberdade assistida, medida que muitos afirmam conhecer e aplicar há muitos anos, requer, no contexto da doutrina da proteção integral, novo entendimento e novas modalidades de execução para que siga os parâmetros dispostos no ECA (BRITO; KOLLER, 2007, p. 135).
\end{abstract}

O Sistema Único de Assistenia Social (SUAS), no que se refere ao trabalho com adolescentes e a efetivação de atividades socioeducativas, com vistas à garantia de direitos e à cidadania, permitiu a implantação de programas específicos para esse grupo etário e sua inclusão em ações de proteção social, bem como a inclusão dos adolescentes em cumprimento de medidas socioeducativas e seus familiares. Essa ótica do ECA, de proteção integral, tem sido fortalecida na sociedade brasileira e há espaços dentro dos serviços de proteção social para atuar nessa direção (BRASIL, 2009a; 2009b).

Para que essas ações sejam efetivadas, a ideia de construção de redes de atenção é estimulada por meio da proposta de integração do SUAS com o Sistema Nacional de Atendimento Socioeducativo (SINASE) e com o Sistema de Garantia de Direitos de Crianças e Adolescentes, além da articulação da Política Nacional de Assistência Social (PNAS) com a Política Nacional de Juventude. A atuação em rede é entendida como meio de fomentar a escuta de demandas polissêmicas/pontuais e assegurar a implementação de programas e ações que contribuam para o enfrentamento das condições de violência e vulnerabilidade, entre indívíduos grupos e comunidades. 
Segundo Sousa e Almeida (2011):

as medidas socioeducativas representam ordens de medidas jurídicas dotadas de coercibilidade, em resposta ao desvalor atribuído ao ato de natureza infracional praticado pelo adolescente, apresentando uma função coercitiva e admitindo a finalidade educativa no processo de sócioeducação (SOUSA; ALMEIDA, 2011, p. $31)$.

O caráter que as medidas socioeducativas assumem está balizado na necessidade de impor limites ao adolescente infrator, na demanda do coletivo social por segurança e na manutenção das normas da sociedade. A LA é uma medida socioeducativa administrada ao adolescente que comete ato infracional, ou, nos casos de progressão de medida, para aqueles egressos de privação de liberdade, compondo o sistema nacional de proteção social em sua modalidade especializada (SOUSA; ALMEIDA, 2011). Dentro das diretrizes do SINASE a LA se tornou uma responsabildiade de núcleos ou centros específicos e, na maioria dos casos, dos CREAS, sendo que suas atividades se desenvolvem nestes locais.

A LA se refere especificamente ao acompanhamento do adolescente em conflito com a lei por um orientador, por no mínimo seis meses, para supervisionar sua promoção social $^{2}$, sua família; sua matrícula, frequência e aproveitamento escolar; bem como sua profissionalização e inserção no mercado de trabalho (Art.118, BRASIL, 2010).

Segundo o ECA, a LA é "adequada para o fim de acompanhar, auxiliar e orientar o adolescente, devendo ser realizada por pessoa capacitada para acompanhar o caso, através de entidade ou programa de atendimento, recomendado pela autoridade judicial" (Art. 118 ${ }^{\circ}$, BRASIL, 2010, p. 3).

O CREAS, para acompanhar os adolescentes em LA, deve possuir uma equipe mínima composta por técnicos de nível superior da área de humanas, preferencialmente, psicólogo, assistente social, pedagogo (um para cada vinte adolescentes), "garantindo-se o atendimento psicossocial e jurídico pelo próprio programa ou pela rede de serviços" (MINAS GERAIS, 2013, p. 33). Esses profissionais devem acompanhar a execução da medida LA, desde a acolhida do adolescente até o seu desligamento (MINAS GERAIS, 2013).

A medida LA consiste basicamente em dois momentos de atendimentos individuais e articulação e encaminhamentos para a rede sócio assistencial do município. Isso propicia ao adolescente a oportunidade de circular pela cidade, utilizando a sua liberdade para conhecer opções saudáveis de vida. Os técnicos devem abordar questões pertinentes à subjetividade do adolescente, às dificuldades relacionadas à sua vida familiar, à sua relação

\footnotetext{
${ }^{2}$ Segundo o, do Estatuto da criança e do adolescente, a promoção social refere-se a "promover socialmente o adolescente e sua família, fornecendo lhes orientação e inserindo-os, se necessário, em programa oficial ou comunitário de auxílio e assistência social” (BRASIL, 2010, Art. 119º, p. 37).
} 
com a comunidade, à saúde, à vida escolar e profissional. A partir disso, o técnico pode construir com o adolescente a sua (re) entrada na rede. Dessa feita, cabe ao técnico intervir na rede sócio assistencial do município visando favorecer a inserção do adolescente nesses espaços, e, desse modo, contribuir para o rompimento com a prática infracional.

Haverá um técnico de referência para cada adolescente. Aquele o acompanhará nos atendimentos individuais e será o responsável por convocá-lo, bem como a sua família, para construir o Plano individual de atendimento do adolescente (PIA). Esse plano consiste em estabelecer metas a serem cumpridas, no âmbito da vida integral do adolescente biopsicossocial-espiritual, trabalhando de forma efetiva as lacunas deixadas em sua vida, reestruturando-a com orientação e acompanhamento ininterruptos, acenando para novas perspectivas de melhoras de vida.

O PIA é um instrumento de registro, acompanhamento e planejamento do adolescente e visa, assim, conhecer a história integral do adolescente, devendo, para tanto, ser analisado e discutido, também, com o adolescente e seu representante legal, pois a liberdade do adolescente de se manifestar e de ser ouvido constitui fator importantíssimo para o efetivo cumprimento da medida, a qual exige voluntariedade e envolvimento da família.

Após a elaboração integral do PIA e a assinatura do contrato socioeducativo celebrado entre o adolescente e a entidade responsável pela execução da medida, inicia-se a fase do "aprendendo a ser", a qual consiste em inserir o adolescente em atividades que o levem a descobrir o próprio corpo e como ele estabelece relação consigo próprio, conhecendo, assim, os seus limites e potencialidades, desenvolvendo hábitos de higiene e saúde, estimulando-o a refletir sobre valores éticos e a se posicionar diante de sua individualidade.

Após cumprir, satisfatoriamente, essa fase, o adolescente é inserido na fase do "aprendendo a conviver", que tem como foco fortalecer as relações familiares e comunitárias, respeitando o outro, reconhecendo ou identificando as diferenças, no sentido de gerenciar seus próprios conflitos, potencializando os valores construtivos que possibilitam a convivência pacífica no meio social. Satisfeitas essas fases, o adolescente deve ser estimulado a buscar a concretização do seu projeto de vida em conformidade com as aptidões e tendências identificadas durante todo o processo de cumprimento da medida de LA.

De acordo com manual elaborado pela Subsecretária de Atendimento as Medidas Socioeducativas (SUASE) Minas Gerais (2013), os atendimentos individuais devem ocorrer ao menos uma vez por semana. Nos demais dias, o adolescente deve estar inserido em atividades na rede e circular pela cidade. Assim, “o adolescente poderá participar das oficinas dos CRAS (Centro de Referência de Assistência Social), oficinas de esporte na comunidade, 
qualificação profissional disponibilizada por Organizações não governamentais (ONGs) ou instituições que ofereçam cursos, atividades para jovens nos centros de saúde, dentre outras atividades" (p. 21). Ainda segundo o documento (p. 37), o processo de atendimento propõe que os profissionais do CREAS desempenhem, entre outras, as seguintes funções:

a. Interessar-se pelo que o adolescente gosta de fazer, sua história, acolher suas demandas, uma vez que isso pode facilitar o estabelecimento de um vínculo;

b. Destacar as questões principais surgidas no discurso do adolescente para direcionar os atendimentos;

c. Analisar o contexto em que o ato infracional surge na história do jovem e ajudá-lo a localizar como tudo aconteceu, posto que a construção de uma cronologia dos fatos de sua história pode facilitar a identificação do que o levou a se envolver na prática infracional;

d. Analisar os vínculos com a escola, família, cursos e trabalho e trabalhar estes pontos;

e. Atendimento à família para análise dos vínculos e sua corresponsabilização no acompanhamento do cumprimento e, mais ainda, como suporte fundamental, após a conclusão da medida;

f. Ofertar ao adolescente os espaços institucionais e externos a partir dos interesses, formas como ele obtém satisfação e, sempre que possível, de maneira conectada com o que foi relatado em atendimento.

Em síntese, a medida de LA prioriza a convivência familiar e comunitária. Apresenta característica de restrição de liberdade, sem ser privativa. Suas ações admitem uma natureza pedagógica, visando promover socialmente o adolescente e sua família, inserindo-o em programa oficial ou comunitário de auxílio de assistência social. Afora isso, promove a inserção escolar do adolescente, bem como diligência no sentido de sua profissionalização e inserção no mercado de trabalho. Oferece, assim, possibilidades para rompimento com a prática de atos infracionais e apoio a construção de um novo projeto de vida (BRITO, 2007).

Incrementar e fortalecer os fatores protetores visando minimizar os efeitos da vulnerabilidade e contribuir para mudanças positivas na trajetória futura de adolescentes, torna-se imperativo (GALO; WILLIANS, 2008; NARDI; DELL' AGLIO, 2012). Nesse sentido, aborda-se, na seção seguinte, a rede social como fator protetor ao adolescente em LA.

\subsection{REDE SOCIAL: FATOR DE PROTEÇÃO A ADOLESCENTES EM LIBERDADE ASSISTIDA}

As situações que envolvem adolescentes em LA podem ser consideradas um exemplo de situações de vulnerabilidade e devem ser enfrentadas ou evitadas a partir da perspectiva das redes sociais, ou seja, a partir de uma rede de relações composta por 
diferentes pessoas, grupos, instituições e parceiros numa lógica em que um fortalece o outro ou em que os vínculos são pensados como fator de proteção ${ }^{3}$.

Como definição, rede social refere-se aos vínculos sociais oriundos das relações humanas, os quais têm impacto duradouro na vida de uma pessoa; inclui todos os vínculos interpessoais, como família, comunidade, amigos, pares, colegas de trabalho e de estudo, entre outros (SLUZKI, 2006, 2010; COSTA, 2009). A rede social propicia, segundo Tomé et al.(2012), autonomia e melhoria da qualidade de vida, aquisição de emprego digno, educação e resgate de valores, contribuindo para a ressocialização e prevenção da recidiva do ato infracional. Nardi, Dell'Aglio (2012) pontuam que ações voltadas à promoção de ambientes protetivos para os adolescentes em conflito com a lei, por meio do fortalecimento da rede social, contribuem de forma significativa para a manifestação de processos de enfrentamento de vulnerabilidades e afastamento dos adolescentes do universo do ato infracional.

Segundo Sluzki (2010), a rede social é um tecido relacional estável, mas em constante evolução, constituído por membros da família, amigos e conhecidos, pessoas do trabalho e da escola, e por relações em/com organizações formais e informais (serviços de saúde, igrejas, políticos, profissionais de saúde, da educação, etc.). Nessa rede, estão incluídos todos aqueles com quem os sujeitos se relacionam, os quais compõem suas histórias e seus sentimentos de satisfação e realização com a vida. Ao analisar de modo mais aprofundado uma rede social, observa-se que ela não somente tem fortes pontos centrados nas pessoas, mas também nas relações sociais e como essas relações se desenham e como são significadas pelas pessoas. As redes, também, favorecem as trocas sociais no que se refere ao convívio, à socialização e ao desenvolvimento de práticas relacionadas com a saúde, a qualidade de vida e o bem-estar.

Assim, pode-se dizer que uma das funções da rede social é oferecer apoio. Esse apoio é necessário para o desenvolvimento do adolescente, a fim de ajudá-lo material e emocionalmente para que se adapte ao meio em que vive, amenizando efeitos negativos dos eventos estressantes em sua vida (PEDRO; ROCHA; NASCIMENTO, 2008). O apoio contribui, ainda, para auxiliar o adolescente em situações de estresse, ajuste social, enfermidades, entre outros (BAO; HAAS; PI, 2007; NARDI; DELL'AGLIO, 2012). O apoio para Sluzki $(2006,2010)$ é encontrado na análise das funções de uma rede. Nela aparecem a

\footnotetext{
3 Segundo o Center for Disease Control and Prevention (2013), fatores de proteção são características, condições ou comportamentos individuais ou ambientais que reduzem o efeito de eventos estressores, aumentando a capacidade de os indivíduos evitarem riscos e promovendo o desenvolvimento de sua competência social e emocional para prosperarem em todos os aspectos de sua vida, presente e futura.
} 
companhia social, o apoio emocional, o guia cognitivo e de conselhos, a regulação e o controle social, a ajuda material e de serviços e o acesso a novos contatos. Assim, tanto a rede social como o apoio se configuram como fatores protetores aos adolescentes envolvidos em prática de atos infracionais, propiciando a eles desenvolver sua capacidade de enfrentamento de adversidades (NARDI; DELL' AGLIO, 2012).

Os fatores protetores mais significativos ao desenvolvimento do adolescente são os vínculos familiares fortes, o êxito escolar, a estabilidade, o apoio mútuo, a capacidade de tomar decisões, as rotinas organizadas, o compartilhamento de sentimentos, a autoestima, a responsabilidade, a competência sócia e emocional, bem como a religiosidade (GALLO; WILIANS, 2008; POLETTO; KOLLER, 2008; NARDI; DELL’'AGLIO, 2012).

Segundo Muller et al. (2009), quando o adolescente em conflito com a lei, no caso em questão aquele em LA, não recebe qualquer tipo de apoio ou assistência ao retornar à sua comunidade de origem, pode se deparar com os mesmos estímulos que o levaram a infringir as normas. Nessa perspectiva, sugere-se que a abordagem ao adolescente em conflito com a lei deve se articular com as diversas redes sociais: família, amigos, vizinhos, comunidade, escola, trabalho e cursos profissionalizantes. Afora isso, Stouthamer-Loeber et al. (2004) destacam o trabalho e a escola como fatores protetores que auxiliam a evitar a reincidência do ato infracional. Portanto, os fatores protetores devem ser estendidos a todas as circunstâncias quando da aplicação da medida socioeducativa de LA.

Assim, pensar a articulação e tessitura de uma rede social efetiva responde às ideias relacionadas à proteção integral proposta pelo ECA, em que crianças e adolescentes se constituem em prioridade absoluta, sendo concebidos como cidadãos plenos sujeitos à proteção prioritária da família, da sociedade e do Estado. Para o ECA, ao adolescente deve ser oferecida a "efetivação dos direitos referentes à vida, à saúde, à alimentação, à educação, ao esporte, ao lazer, à profissionalização, à cultura, à dignidade, ao respeito, à liberdade, à convivência familiar e comunitária" (BRASIL, 2010, Art. $4^{\circ}$, p.31 ).

A fim de melhor compreender as redes sociais, Sluzki (2010) defende a sua caracterização em termos de suas estruturas, funções e atributos dos vínculos. Para isso, propõe a construção de um mapa mínimo que leve em consideração todas as relações da pessoa, sendo dividido em quatro quadrantes: família, amizades, relações de trabalho ou estudo, relações comunitárias, serviços de saúde e agências sociais, conforme ilustra a figura a seguir: 


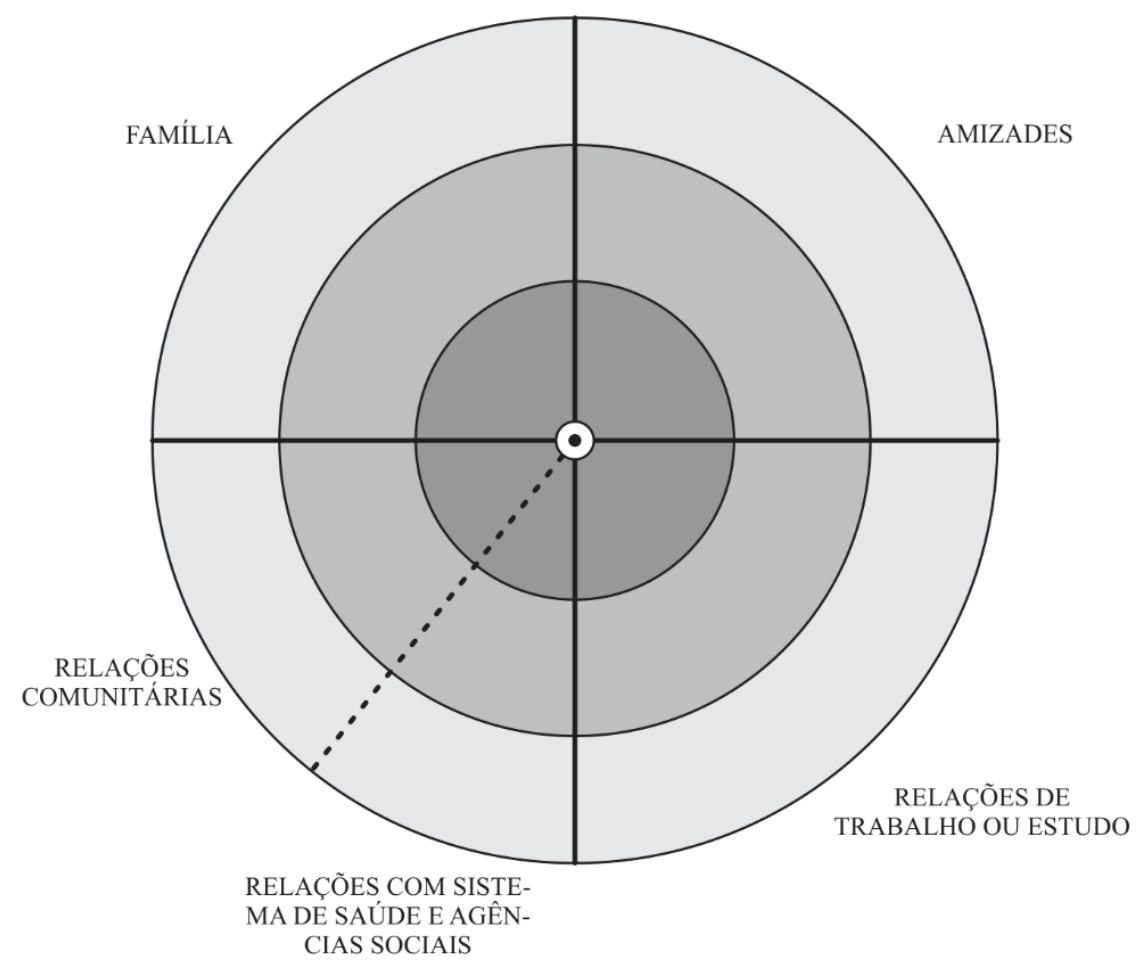

LEGENDA

Adolescente

Vínculo Significativo

-. . Vínculo Fragilizado

Vínculo Rompido

Relações íntimas

(família e grupo significativo)

Relações sociais

(com contato pessoal)

Conhecidos

(relações ocasionais distantes)

Figura 2 - Modelo de Mapa de Rede Social proposto por Sluzki (2010)

Na figura, o núcleo do círculo representa o sujeito, o primeiro círculo é menor e representa as relações íntimas de proximidade; o segundo círculo representa as relações sociais com menor proximidade e o terceiro círculo refere-se às relações com conhecido.

Como este mapa foi utilizado como procedimento metodológico de coleta de dados, este será mais bem delineado no capítulo percurso metodológico.

Mapas de rede social têm sido utilizados em pesquisas da área da saúde para auxiliar na compreensão da constituição da rede de adolescentes. BRAGA et al. (2014), a exemplo, realizaram um estudo que objetivou analisar as percepções de mães adolescentes 
sobre o apoio social na maternidade Os autores concluíram que o apoio percebido pelas adolescentes era frágil e com lacunas, podendo a enfermagem contribuir para a construção do cuidado integral em saúde e potencializar as condições de vida das adolescentes na medida em que pode se apropriar da concepção da rede social na função do apoio como um fator de proteção.

O estudo de Dezoti et al. (2013) também usou a técnica dos mapas de rede social com o objetivo de identificar as redes sociais de famílias para a promoção do desenvolvimento infantil na perspectiva da equipe da Estratégia Saúde da Família (ESF). O estudo revelou que as redes sociais têm importante papel na vinculação das famílias, fortalecendo seu potencial para o desenvolvimento infantil saudável. Os autores recomendaram que os profissionais de saúde articulem ações que possam influenciar esses elementos de maneira que promovam o desenvolvimento infantil adequado, considerando os mapas como elementos chaves na elaboração das estratégias de cuidado integral.

Por fim, Alexandre et al. (2012) realizaram uma pesquisa que objetivou identificar a rede social de famílias para a promoção do desenvolvimento infantil. Os autores consideram que o entendimento por parte dos profissionais de saúde sobre a importância da rede social favorece as propostas de atenção integral a diferentes populações.

Em síntese, os estudos que utilizam os mapas têm revelado importantes resultados para a compreensão de processos de vida e de como a concepção das redes pode contribuir para a construção de práticas em saúde, principalmente. 


\section{PRESSUPOSTOS}

Este estudo focaliza o envolvimento de adolescentes em atos infracionais e o consequente cumprimento de medida socioeducativa no âmbito da liberdade assistida (LA) e da proteção social especial. Essa medida socioeducativa não se refere a um fenômeno isolado, tampouco específico da realidade local investigada, mas a uma problemática que, nas últimas décadas, desperta a atenção de pesquisadores e profissionais que atuam em diferentes áreas, como a saúde, a assistência social, a área jurídica e a educação.

Nesse sentido, este estudo partiu do pressuposto de que é possível, a partir da investigação das falas e mapas de rede social de adolescentes em LA, perceber e elencar o sentido, a estrutura, a função e o tipo de vínculo presentes nessas redes, considerando, para tanto, que a realidade em que vivem esses adolescentes é marcada por situações de vulnerabilidades que podem favorecer o envolvimento com o ato infracional, ao passo que a rede social pode oferecer fatores de proteção.

Acredita-se que uma rede social, com vínculos fortes, possibilita a regulação da conduta infracional dos adolescentes em LA, proporcionando-lhes promoção social e possibilidades de trajetória de vida saudável, responsável e distante do crime. 


\section{PERCURSO METOdOLÓGICO}

\subsection{CARACTERIZAÇÃO DO ESTUDO}

Trata-se de um estudo exploratório, descritivo, de abordagem qualitativa. Este tipo de delineamento é o mais indicado para captar e conhecer aspectos do comportamento verbal e gestual, assim como potencializar a participação dos sujeitos no que se refere à espontaneidade e à diversidade de respostas (FLICK, 2009). Nessa mesma perspectiva, Minayo (2010) pontua que a abordagem qualitativa é aplicada ao estudo da história, das relações, das representações, das crenças, das percepções, das opiniões, das interpretações que os humanos fazem a respeito de como vivem, constroem seus artefatos e a si mesmos. Segundo a autora, essa abordagem permite ao pesquisador desvelar processos sociais, sob a ótica dos sujeitos envolvidos na pesquisa.

Assim, essa modalidade de estudo é adequada para a investigação proposta nesta tese, uma vez que o foco nos sentidos atribuídos à rede social de adolescentes em LA reflete a construção histórica da maneira que representam a vida, a sociedade e a cultura nesse momento do desenvolvimento humano, revelando contextos e tópicos constitutivos da identidade e da forma de pensar, sentir e reagir em sociedade (ARAÚJO, VIEIRA, CAVALCANTE, 2009).

\subsection{CAMPO DE ESTUDO}

A pesquisa foi realizada no CREAS do município de Patos de Minas. A cidade se localiza no interior de Minas Gerais, na região intermediária entre o Triângulo Mineiro e o Alto Paranaíba. O município possui uma base territorial de $3.189 .006 \mathrm{~km}^{2}$, com população estimada em 146.416 mil habitantes (INSTITUTO BRASILEIRO DE GEOGRAFIA E ESTATÍSTICA, 2011) e Índice de Desenvolvimento Humano (IDH) de 0,765 (Programa das Nações Unidas para o Desenvolvimento, 2010). O número estimado da população com idade entre 12 a 18 anos é de 18.692 habitantes, o que corresponde a 8,5\% da população total, considerado um número razoável de adolescentes residentes no município (INSTITUTO BRASILEIRO DE GEOGRAFIA E ESTATÍSTICA, 2011).

Patos de Minas é uma das 20 maiores cidades do Estado de Minas Gerais. Considerada pólo econômico regional, a cidade ganhou projeção nacional especialmente 
devido à Festa Nacional do Milho. Sua economia centra-se na agricultura, com diversidade na produção de grãos e hortifrutigranjeiros, e na pecuária, com a bovinocultura. A localização privilegiada, que liga a cidade a grandes centros comerciais como São Paulo, Uberlândia e Belo Horizonte, favoreceu o desenvolvimento econômico do município.

A oferta a serviços de saúde no município ocorre por meio de um Centro de Atenção Psicossocial, um Centro de Atenção Hemoterápica, 16 Unidades Básicas de Saúde, 24 Ambulatórios Especializados, três policlínicas privadas, 19 unidades de serviço de apoio de diagnose e terapia, uma Unidade Pronto Atendimento porte III e cinco hospitais gerais.

A atenção básica de saúde está organizada em 38 equipes da ESF que abrange uma cobertura de $90 \%$ da população. Existem ainda três equipes do Núcleo de Apoio a Saúde da familia (NASF) para complementar as atividades de prevenção e promoção à saúde da rede de atenção básica. O sistema educacional oferece ensino para crianças, adolescentes, jovens e adultos, sendo que existem na cidade centros de educação infantil, escolas municipais e estaduais.

As instâncias que compõem o Sistema de Garantia de Direitos dos adolescentes na cidade são: Poder Judiciário, Promotoria de Justiça, Coordenadoria Regional da Infância e Juventude, Conselho Tutelar, Conselho Municipal dos Direitos da Criança e do Adolescente, Conselho Municipal de Assistência Social, Defensoria Pública, Juizado da Infância e Juventude, Batalhão de Polícia Militar, Delegacia Regional de Polícia Civil, Conselho de Segurança Pública, Secretaria Municipal de Saúde, Secretaria Municipal de Desenvolvimento Social e Secretaria Estadual e Municipal de Educação.

No que se refere à organização do município para proteção social especializada, identificou-se o CREAS, que é uma unidade pública estatal, responsável pela oferta de atenção, orientação e acompanhamento a sujeitos e famílias com um ou mais de seus membros em situação de ameaça ou violação de direitos. Esse serviço realiza atendimentos prioritários aos adolescentes que cumprem a medida socioeducativa de LA. No CREAS atua uma equipe multiprofissional composta por assistente social, psicólogo, pedagoga e advogado, que são os técnicos-orientadores que acompanham os adolescentes em LA. A medida LA e o CREAS trabalham na perspectiva da emancipação e do empoderamento dos adolescentes, evitando a recidiva do ato infracional. Vale destacar que o CREAS é a única instituição no município de Patos de Minas que realiza esse acompanhamento. 


\subsection{PARTICIPANTES DO ESTUDO}

Participaram deste estudo 26 adolescentes com idades entre 13 a 18 anos que cumpriam a medida sócio educativa LA no CREAS de Patos de Minas. Vale lembrar que essa é a faixa etária preconizada como período da adolescência pelo ECA (BRASIL, 2010). O grupo de participantes foi selecionado de acordo com os seguintes critérios de inclusão: adolescentes com idade de 12 a 18 anos que cumpriam a medida LA em 2014 no momento da coleta de dados, independente do tempo em que estavam cumprindo a medida de LA.

Para garantir o anonimato e o sigilo das informações dos adolescentes, a pesquisadora solicitou que cada um deles escolhesse um apelido pelo qual foram identificados no estudo. As designações por eles atribuídas foram: Amizade (adolescente 1); Aventura (adolescente 2); Branco (adolescente 3); Branquinha (adolescente 4); Cachaça (adolescente 5); Cantora (adolescente 6); Companheiro (adolescente 7); Capoeira (adolescente 8); Dança (adolescente 9); Esporte (adolescente 10); Festa (adolescente 11); Futebol (adolescente 12); Igreja (adolescente 13); Lagoa (adolescente 14); Lutador (adolescente 15); Moda (adolescente 16); Moreninha (adolescente 17); Moreno (adolescente 18); Motorista (adolescente 19); Namorador (adolescente 20); Prestativo (adolescente 21); Piercing (adolescente 22); Tean Sagow (adolescente 23); Tímido (adolescente 24); Violão (adolescente 25); Vergonhoso (adolescente 26). Para efeito de esclarecimento, a partir de agora os adolescentes serão referidos por estas designações.

\subsection{INSTRUMENTOS PARA COLETA DE DADOS}

Para a coleta de dados foram utilizados dois instrumentos: um roteiro de entrevista semiestruturada (Apêndice A) e a construção de mapas de rede social dos adolescentes em LA (Apêndice B).

O roteiro para a entrevista semiestruturada (Apêndice A) foi constituído por dois blocos: 1) dados sócio demográficos como idade, sexo, escolaridade, condições de moradia, composição familiar, renda familiar, atividade produtiva (trabalho), ano escolar que frequentava, tempo de cumprimento da LA e tipo de ato infracional cometido (dados registrados junto aos adolescentes pela pesquisadora); 2) nove questões norteadoras que abordavam o sentido da rede social dos adolescentes em LA, com o intuito de conhecer as potencialidades e lacunas de sua rede social. 
O mapa de rede social, adaptado de Sluzki (2006; 2010), foi aplicado junto aos adolescentes para se conhecer sua rede social. Como mencionado no referencial teórico desta tese, o mapeamento das redes sociais é um instrumento valioso para tentar verificar como estão constituídos os vínculos do sujeito e como está sua qualidade de vida, permitindo visualizar, graficamente, os níveis de relacionamento construídos nos diferentes campos interacionais, como a família, as relações comunitárias, as amizades, o trabalho, escola, as agências de saúde e as agências sociais.

O mapa de rede social proposto por Sluzki (2010) constitui-se de três círculos concêntricos divididos em quatro quadrantes, os quais se relacionam a família, as amizades, as relações de trabalho ou escolares, as relações comunitárias e as relações de serviço de saúde e as agências sociais. No mapa, o núcleo do círculo representa o sujeito; o primeiro círculo é menor e representa as relações íntimas de proximidade, o segundo representa as relações sociais com menor proximidade e o terceiro círculo refere-se às relações com conhecidos (Figura 2).

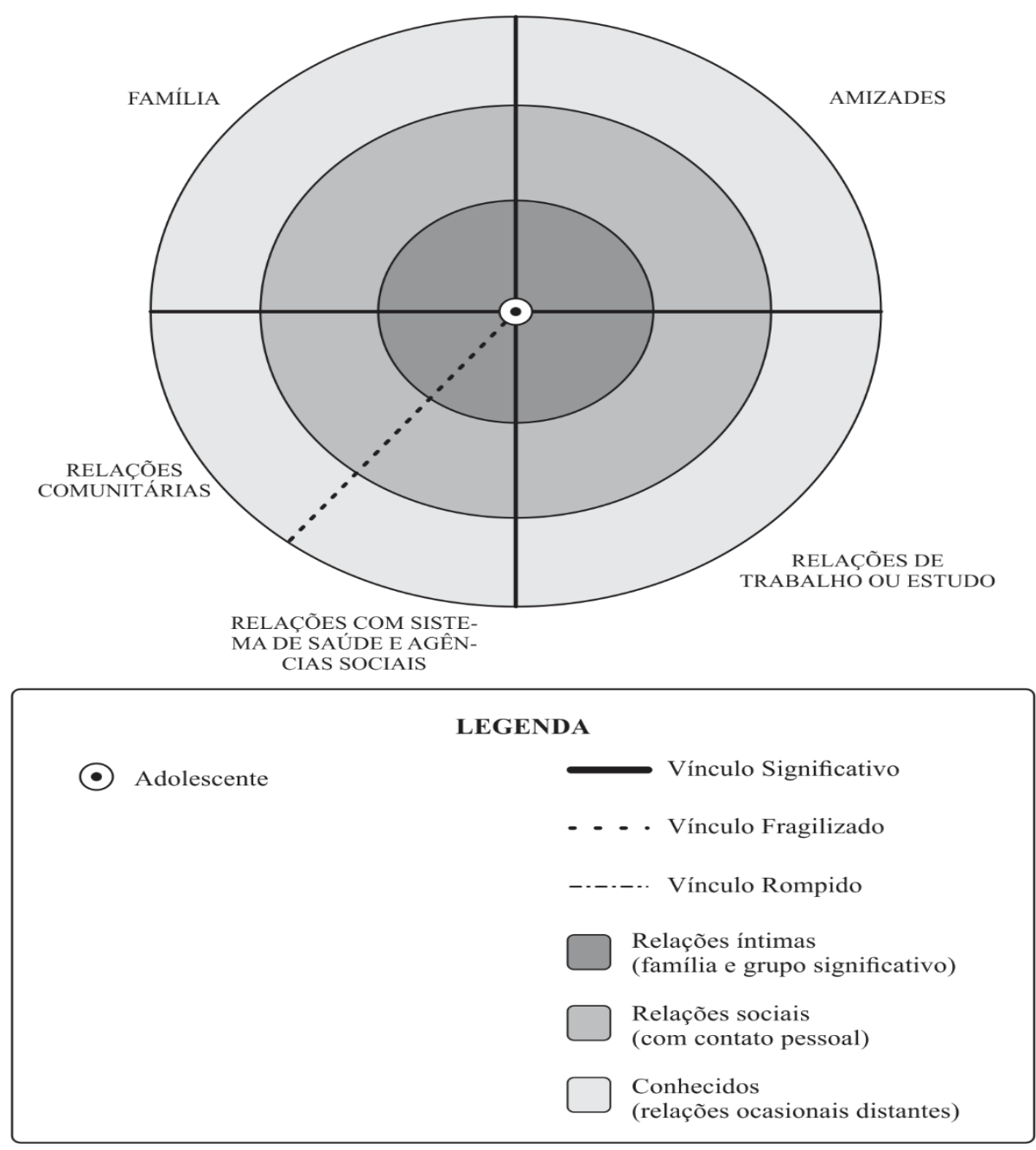

Figura 2-Modelo de Mapa de Rede Social proposto por Sluzki (2010) 
As configurações do tipo de relações sejam elas íntimas, ou sociais e/ou com conhecidos, permitem identificar os níveis de relações que podem variar a) de maior grau de confiabilidade e intimidade, como as relações entre os familiares e os amigos; b) de menor grau de comprometimento, constituídas por colegas de escola e trabalho; e c) pessoas conhecidas, que se situam mais distanciadas ou que surgem de maneira ocasional (UDE; FELIZARDO JUNIOR, 2009).

Procurou-se, também, visualizar a significância dos vínculos. Segundo a proposta de Sluzki (2010), utilizaram-se diferentes linhas para representa-los. Assim, para os vínculos significativos, como relações de confiança, amizade, solidariedade, reciprocidade e intimidade, foram representadas graficamente por uma linha contínua. Os vínculos fragilizados, com relações tênues, foram graficamente apresentados por meio de uma linha entrecortada. Já os vínculos rompidos ou inexistentes foram representados por meio de uma linha quebrada.

Ainda segundo Sluzki (2010), a rede deve ser avaliada na dimensão de suas características estruturais (propriedade de rede em seu conjunto), das funções dos vínculos (tipo predominante de intercâmbio interpessoal) e dos atributos de cada vínculo (propriedade específica de cada relação).

Sluzki (2010) define a necessidade de avaliar, na dimensão estrutural da rede, os seguintes componentes:

a) Tamanho: número de pessoas na rede. Esta pode ser classificada como reduzida, mediana ou ampliada.

b) Densidade: qualidade dos vínculos observados, tanto no nível pessoal quanto institucional no que tange às linhas do traçado: significativos, fragilizados, rompidos ou inexistentes.

c) Distribuição/composição: refere-se ao número de pessoas ou instituições situadas em cada quadrante. Aqui, denotam-se lacunas e recursos existentes na rede.

d) Dispersão: trata-se da distância geográfica entre membros e instituições. Esse fator pode ser facilitador de acesso ou dificultar contatos e apoios mútuos no cotidiano dos sujeitos.

e) Homogênea ou heterogênea: avalia as características dos membros e das instituições no intuito de verificar a diversidade e as semelhanças que compõem a rede. Uma rede homogênea torna-se fechada e frágil por não permitir diálogos com as diferentes organizações e individualidades que constituem a vida social em comunidade. 
Entre esses fatores, acrescentam-se outros componentes importantes como conhecer as funções do vínculo. Assim sendo, Sluzki (2010) elenca alguma dessas funções:

a) Companhia social: parte do princípio que isolados somos frágeis, tanto como pessoa quanto instituição. Nesse sentido, refere-se às necessidades e possibilidades de atividades coletivas e compartilhadas, as quais propiciam inúmeras alternativas e estratégias para se enfrentar problemas diários.

b) Apoio emocional: trata-se da presença compreensiva frente às adversidades da vida, por meio do acolhimento, da escuta, do estímulo e da simpatia.

c) Guia cognitivo e de conselhos: trata-se do auxílio ao adolescente no sentido de oferecer-lhe informações pessoais e sociais e esclarecimentos que podem ajudá-lo na tomada de decisões em sua vida.

d) Regulação e controle social: o diálogo e a convivência permanentes estabelecem princípios, critérios e valores que lembram e reafirmam responsabilidades, papéis e normas que se tornam parâmetros para regular postura pessoais e grupais.

e) Ajuda material e de serviços: o compartilhamento de recursos materiais e de conhecimentos constitui a materialização de uma proposta em redes.

f) Acesso a novos contatos: o envolvimento junto a redes cooperativas e solidárias possibilita a construção de novos vínculos com pessoas e grupos, ampliando a rede social dos sujeitos.

Sluzki (2010) explicita ainda que cada vínculo do sujeito pode ser analisado de acordo com seus atributos, podendo estes ser interdependentes e combinarem entre si. Para o autor, esses atributos podem ser analisados em quatro aspectos, quais sejam:

a) Funções predominantes: a função predominante que caracteriza o vínculo.

b) Multidimensionalidade: a quantidade de funções desempenhadas pelo componente da rede; a reciprocidade: se a relação é recíproca, simétrica ou assimétrica.

c) Intensidade: o grau de intimidade da relação.

d) A frequência dos contatos: a constância da aproximação entre as pessoas da rede.

No caso específico deste estudo, o mapa de rede social foi utilizado como gerador de uma imagem gráfica que permitiu o acesso à "lista" de pessoas e instituições com os quais os adolescentes se relacionavam. Nessa abordagem, foi possível identificar fatores protetores apontados pelo desenho construído. 


\subsection{PROCEDIMENTOS PARA COLETA DE DADOS}

Em novembro de 2013, com prévio contato com a diretora do CREAS, foi realizado uma reunião com todos os profissionais da equipe, momento em que a pesquisadora apresentou a proposta e os objetivos do estudo, sendo esta também uma estratégia de aproximação com o campo de pesquisa. Após a autorização da unidade para a realização do estudo, o projeto de pesquisa foi submetido ao Comitê de Ética em Pesquisa (CEP) da Escola de Enfermagem de Ribeirão Preto (EERP), Universidade de São Paulo (USP) e aprovado pelo mesmo.

Após a identificação dos possíveis adolescentes que atendiam aos critérios de inclusão, vislumbrou-se a necessidade de mais aproximação e vínculo entre a pesquisadora e os participantes para, então posteriormente, convidá-los a participar do estudo. Esta aproximação ocorreu por meio de visita regular ao CREAS, de atendimento conjunto com os profissionais do CREAS, de participação de oficinas de teatro e de reuniões com os pais e adolescentes em LA.

Nesse momento, a pesquisadora realizou um estudo piloto com quatro adolescentes em LA, selecionados de forma aleatória, para melhor adequar o roteiro da entrevista e o vocabulário utilizado na coleta de dados. Buscou-se, também, verificar se os instrumentos possibilitavam, de fato, coletar os dados para a efetivação do estudo proposto. Para isso, os adolescentes e seus responsáveis assinaram o Termo de Consentimento Livre e Esclarecido e o Termo de Assentimento (Apêndice C, D e E).

No início de 2014, a pesquisadora participou de uma reunião com os adolescentes e os seus pais ou responsáveis na qual pôde apresentar a pesquisa, esclarecer os objetivos do estudo e realizar o convite para participação. Estiveram presentes 26 adolescentes em LA e seus respectivos responsáveis. Nesse encontro, a pesquisadora solicitou a concordância dos adolescentes e a permissão de seus pais ou responsáveis. Todos os presentes concordaram em participar do estudo e assinaram o Termo de Consentimento Livre e Esclarecido e o Termo de Assentimento (Apêndice C, D e E). Vale a pena lembrar que os quatros adolescentes do estudo piloto não estavam nesta reunião e não fizeram parte da composição dos 26 adolescentes.

Posteriormente foram agendadas as entrevistas conforme disponibilidade dos adolescentes. Os dados das entrevistas e dos mapas foram coletados entre os meses de janeiro e março de 2014, na unidade do CREAS, em uma sala privativa. Coletaram-se os dados nos dias em que os adolescentes iriam para o atendimento, evitando-se, assim, interromper ou 
dificultar o atendimento técnico da equipe ao adolescente. Tanto as entrevistas individuais quanto a construção dos mapas de rede foram realizadas no mesmo dia.

As entrevistas foram gravadas em áudio. Para a construção dos mapas de rede foram oferecidos aos adolescentes um lápis e uma cópia impressa do instrumento para que fossem registrados os nomes de pessoas e instituições em cada uma das suas dimensões. Estes procedimentos, em seu conjunto, teve uma duração média de 30 minutos. Após o preenchimento do mapa de rede social, exploraram-se as questões relativas à avaliação da dimensão estrutural, como a composição, o tamanho e a distribuição dos membros. Já nas funções dos vínculos, buscou-se conhecer aspectos relacionados à companhia social, ao apoio emocional, ao guia cognitivo e de conselhos, a regulação e ao controle social, a ajuda material e de serviços, e ao acesso a novos contatos. Em relação aos tipos de vínculos, foram caracterizados os significativos, os fragilizados e os rompidos ou inexistentes.

\subsection{PROCEDIMENTOS PARA ANÁLISE DOS DADOS}

A transcrição das entrevistas foi realizada na íntegra pela pesquisadora e sua análise ocorreu segundo o método de interpretação de sentidos. A interpretação dos sentidos se refere a uma "perspectiva das correntes compreensivas das ciências sociais que analisa: a) palavra; b) ações; c) conjunto de inter-relações; d) grupos; e) instituições; f) conjunturas, dentro outros corpos analíticos" (GOMES et al., 2005, p. 202). Os fundamentos dessa abordagem contextual de análise é a hermenêutica dialética, que busca alcançar as razões e as lógicas dos depoimentos que giram em torno das temáticas da proposta do estudo.

O método se pauta na interpretação, caminhando além dos conteúdos de textos na direção de seus contextos, revelando, de modo mais abrangente, as lógicas e as explicações dos sujeitos tendo em vista seu contexto de vida e sua cultura. Procura-se articular concepções da filosofia e das ciências sociais, tentando caminhar tanto na compreensão (atitude hermenêutica) quanto na crítica (atitude dialética) dos dados gerados de uma pesquisa, o que é favorecido com a combinação de métodos (GOMES, 2009; 2014).

$\mathrm{Na}$ trajetória analítico-interpretativa seguiram-se os seguintes passos: a) leitura compreensiva e exaustiva, visando à visão do conjunto de falas e a apreensão das particularidades do material coletado; b) identificação e problematização das ideias explícitas e implícitas no conjunto de dados; c) identificação e recorte temático dos depoimentos sobre as redes sociais dos adolescentes em LA; d) busca de sentidos mais amplos (sócioculturais) que articulam as falas dos sujeitos da pesquisa e as marcas das redes sociais; e) diálogo entre 
sentidos atribuídos, informações provenientes de outros estudos acerca do assunto e o referencial teórico do estudo; e f) elaboração de síntese interpretativa, procurando articular o objetivo do estudo à base teórica adotada e aos dados empíricos (GOMES, 2009; 2014).

A partir disso, foram identificados quatro núcleos de sentido que foram explorados nos resultados e discussão dos dados: 1) serviços e engajamento social; 2) membros da rede social: destaque para figuras femininas; 3) essencialidade da rede social e 4) processo de adolescer e o cumprimento da LA.

A análise do mapa de rede social também seguiu esse olhar contextual em relação aos dados coletados nas entrevistas, sendo, portanto, consideradas as características da estrutura, da função e dos atributos dos vínculos da rede social. Ademais, para melhor compreender a rede social dos adolescentes, as informações foram compiladas em tabelas. Estas levaram em consideração não somente os níveis de relações estabelecidas com cada pessoa ou instituição mencionada por cada adolescente, mas também os quadrantes em que cada uma delas se encontrava, tanto no nível individual de cada caso, quanto em perspectivas coletivas, de conjunto. As tabelas elaboradas também objetivaram facilitar a leitura e interpretação dos resultados.

\subsection{ASPECTOS ÉTICOS}

Este estudo foi submetido e aprovado pelo CEP da EERP-USP, conforme CAAE (Certificado de Apresentação para Apreciação Ética) no 12756713.4.0000.5393, em 24 de junho de 2013 (Anexo A), respeitando-se as prerrogativas da Resolução 466/2012 do Conselho Nacional de Saúde (CNS). Aos participantes adolescentes maiores de 18 anos foram solicitados o consentimento, mediante assinatura do Termo de Consentimento Livre Esclarecido (Apêndice C) e para os menores de 18 anos foi solicitado seu assentimento e o consentimento dos seus pais ou responsáveis legais, mediante assinatura do Termo de Assentimento e do Termo de Consentimento Livre Esclarecido (Apêndice D e E), respectivamente.

Os propósitos, procedimentos e objetivos do estudo foram devidamente explicados utilizando-se de uma linguagem clara e acessível aos participantes e seus responsáveis, visando salvaguardar seus direitos e sua opção em relação a participar ou não da pesquisa. 


\section{RESULTADOS E DISCUSSÃO}

Inicialmente apresenta-se a caracterização dos adolescentes em LA participantes do estudo. Na sequência, descreveram-se, também, as características da rede social preconizadas por Sluzki (2010). Na dimensão estrutural foram abordados aspectos sobre o tamanho, a densidade, a composição, a dispersão e a homogeneidade ou heterogeneidade. Já na dimensão funcional foram abordados aspectos sobre a companhia social, o apoio emocional, o guia cognitivo e os conselhos, a regulação e o controle social, a ajuda material e de serviços, e o acesso a novos contatos. Em relação aos atributos analisou-se o conjunto dos mapas de rede social dos adolescentes em LA, para determinar as funções predominantes, a multidimensionalidade, a intensidade e a frequência dos vínculos. Os dados foram apresentados no conjunto e para tanto se optou por construir tabelas e quadros buscando a visualização de aspectos gerais das análises realizadas. Por fim, apresentaram-se os quatro núcleos de sentido bem como sua discussão à luz da literatura científica.

\subsection{PERFIL DOS ADOLESCENTES PARTICIPANTES DO ESTUDO}

Ao realizar um levantamento sobre o perfil dos adolescentes em LA que participaram deste estudo, foi possível construir a seguinte tabela 1 descrita na pagina seguinte. Nela, mostram-se as porcentagens desses adolescentes considerando-se sexo, idade, moradia, renda familiar, religião, frequência e evasão escolar, trabalho, tipo de ato infracional praticado e tempo de cumprimento da medida LA.

Analisando-se os dados apresentados na tabela, pode-se constatar que os adolescentes em LA são, em sua maioria, do sexo masculino (73\%), possuem experiências de repetência escolar $(73 \%)$, frequentam a escola $(80,8 \%)$, pertencem a igrejas evangélicas $(61,6 \%)$ e residem em casas alugadas (77\%). Em relação à idade, há adolescentes com 17 $\operatorname{anos}(27 \%), 18$ e $15 \operatorname{anos}(19,2 \%), 14$ e $16 \operatorname{anos}(15,4 \%)$ e 13 anos (3,8\%). A renda familiar predominante foi de um a dois salários mínimos e somente 10 dos 26 adolescentes relataram atividade laboral. Em relação ao tipo de ato infracional cometido, destacam-se roubos $(38,5 \%)$ e brigas $(19,2 \%)$. Essa caracterização possibilitou conhecimento de diversas particularidades dos adolescentes participantes deste estudo, as quais são importantes e refletem na estruturação e configuração de sua rede social. 
Tabela 1- Perfil dos adolescentes em liberdade assistida. Patos de Minas, Minas Gerais, Brasil, 2014. ( $\mathrm{n}=26)$.

\begin{tabular}{|c|c|c|}
\hline Sexo & $\mathbf{N}^{\mathbf{0}}$ & $\%$ \\
\hline Masculino & 19 & 73,0 \\
\hline Feminino & 7 & 27,0 \\
\hline \multicolumn{3}{|l|}{ Idade } \\
\hline 13 anos & 01 & 3,8 \\
\hline 14 anos & 04 & 15,4 \\
\hline 15 anos & 05 & 19,2 \\
\hline 16 anos & 04 & 15,4 \\
\hline 17 anos & 07 & 27,0 \\
\hline 18 anos & 05 & 19,2 \\
\hline \multicolumn{3}{|l|}{ Moradia } \\
\hline Alugada & 20 & 77,0 \\
\hline Cedida por outras pessoas & 06 & 23,0 \\
\hline \multicolumn{3}{|l|}{ Renda familiar } \\
\hline 1 salário mínimo & 06 & 23,0 \\
\hline 2 salários mínimos & 12 & 46,2 \\
\hline 3 salários mínimos & 03 & 11,6 \\
\hline 4 salários mínimos & 03 & 11,6 \\
\hline 6 salários mínimos & 01 & 3,8 \\
\hline 7 salários mínimos & 01 & 3,8 \\
\hline \multicolumn{3}{|l|}{ Religião } \\
\hline Evangélica & 16 & 61,6 \\
\hline Espírita & 05 & 19,2 \\
\hline Outras & 01 & 3,8 \\
\hline Nenhuma & 04 & 15,4 \\
\hline \multicolumn{3}{|c|}{ Adolescentes que frequentava a escola } \\
\hline Sim & 21 & 80,8 \\
\hline Não & 05 & 19,2 \\
\hline \multicolumn{3}{|c|}{ Adolescentes em repetência escolar } \\
\hline Sim & 19 & 73,0 \\
\hline Não & 07 & 27,0 \\
\hline \multicolumn{3}{|l|}{ Adolescente que trabalham } \\
\hline Sim & 10 & 38,5 \\
\hline Não & 16 & 61,5 \\
\hline \multicolumn{3}{|l|}{ Tipo de ato infracional } \\
\hline Roubo & 10 & 38,5 \\
\hline Briga & 05 & 19,2 \\
\hline Envolvimento com o Tráfico & 04 & 15,4 \\
\hline Dirigir sem habilitação & 03 & 11,6 \\
\hline Porte de arma branca & 02 & 7,7 \\
\hline Crime contra patrimônio & 01 & 3,8 \\
\hline Identidade falsa & 01 & 3,8 \\
\hline \multicolumn{3}{|c|}{ Tempo de cumprimento da LA } \\
\hline Menos de 6 meses & 16 & 61,5 \\
\hline Mais de 6 meses & 10 & 38,5 \\
\hline
\end{tabular}




\subsection{A REDE SOCIAL DOS ADOLESCENTES EM LIBERDADE ASSITIDA}

Na tabela 2, a seguir, apresentam-se dados relativos ao tamanho e à composição dos membros da rede em cada tipo de relação estabelecida no mapa de rede social dos adolescentes em LA.

Nessa perspectiva, relações íntimas são aquelas estabelecidas com familiares, amigos e colegas presentes no dia a dia. Relações sociais são aquelas com menor grau de compromisso, envolvendo familiares e pessoas não muito presentes. Já relações ocasionais, são aquelas que envolvem pessoas distantes, como conhecidos de escola e de trabalho. Vale lembrar que redes compostas por uma a sete pessoas são consideradas pequenas. Aquelas compostas por oito a 10 pessoas são consideradas médias e aquelas compostas por mais de 11 pessoas são consideradas grandes.

Tabela 2 - Composição da rede social dos adolescentes em liberdade assistida, segundo as relações intimas, sociais e com conhecidos. Patos de Minas, MG, Brasil, 2014 . (n=26)

\begin{tabular}{lcccc}
\hline Adolescente & Relações íntimas & Relações Sociais & $\begin{array}{c}\text { Relações com } \\
\text { conhecidos }\end{array}$ & $\begin{array}{c}\text { No de pessoas na } \\
\text { rede }\end{array}$ \\
\hline Amizade & 8 & 3 & 1 & 12 \\
Aventura & 3 & 2 & 1 & 6 \\
Branco & 3 & 0 & 0 & 3 \\
Branquinha & 5 & 0 & 0 & 5 \\
Cachaça & 4 & 0 & 0 & 4 \\
Cantora & 9 & 0 & 0 & 9 \\
Capoeira & 5 & 2 & 0 & 7 \\
Companheiro & 6 & 0 & 0 & 6 \\
Dança & 4 & 2 & 0 & 6 \\
Esporte & 3 & 1 & 2 & 6 \\
Festa & 5 & 0 & 1 & 6 \\
Futebol & 6 & 1 & 1 & 8 \\
Igreja & 4 & 0 & 1 & 5 \\
Lagoa & 4 & 0 & 1 & 5 \\
Lutador & 10 & 1 & 0 & 8 \\
Moda & 6 & 1 & 1 & 7 \\
Moreninha & 6 & 1 & 0 & 5 \\
Moreno & 4 & 2 & 0 & 12 \\
Motorista & 10 & 1 & 0 & 4 \\
Namorador & 3 & 1 & 0 & 11 \\
Piercing & 9 & 1 & 1 & 8 \\
Prestativo & 7 & 1 & 0 & 8 \\
Tean Sagow & 7 & 2 & 0 & 6 \\
Tímido & 4 & 0 & 0 & 2 \\
Vergonhoso & 1 & 1 & 1 & 7 \\
Violão & 5 & 25 & 1 & 178 \\
\hline Total & 141 & & 14 & \\
\hline
\end{tabular}


Em relação ao tamanho da rede, observou-se que 17 adolescentes apresentaram uma rede social significativamente pequena (Aventura, Branco, Branquinha, Cachaça, Capoeira, Companheiro, Dança, Esporte, Festa, Igreja, Lagoa, Moreninha, Moreno, Namorador, Tímido, Vergonhoso, Violão). Autores como Bullock (2004); Alarcão (2007); Sluzki (2010), asseveram que este tipo de rede é menos efetiva em situações de sobrecarga ou tensão de longa duração, já que os membros começam a evitar o contato para evitar a sobrecarga.

Por sua vez, Moreira e Sarriera (2008) apontam para o entendimento que mesmo sendo a rede pequena, o que influencia é o tipo de intensidade do vínculo, ou seja, independente da quantidade de pessoas com quem se possa contar, o importante é ter a percepção que se pode contar, verdadeiramente, com alguma pessoa. Segundo Alarcão (2007) e Sluzki (1997; 2010) e não é positivo a rede social ser de tamanho reduzido, pois essa característica pode sobrecarregar os membros a ela pertencentes, traduzindo-se em um esgotamento dos recursos. Ainda segundo esses autores, o problema de a rede ser pequena é que a falta de qualquer membro pode representar uma perda significativa.

Cinco adolescentes (Cantora, Futebol, Moda, Prestativo e Tean Sagow) citaram uma rede média, ou seja, considerada eficiente de acordo com a literatura, no sentido de uma maior distribuição da sobrecarga do apoio oferecido. Redes de tamanho médio (entre oito e dez pessoas), na infância e adolescência, têm sido indicadas pela literatura como as ideais por amenizarem os problemas apresentados pelas redes grandes e pequenas (MENDES, 2011).

Por sua vez, apenas quatro adolescentes (Amizade, Lutador, Motorista e Perci) citaram uma rede grande, o que indicia a possibilidade de essa rede não ser efetiva, já que os membros podem ter a suposição de que alguém já esteja "cuidando do problema" (Sluzki, 1997, p. 46). Nessa perspectiva, as redes muito numerosas podem conduzir a um maior descompromisso; os membros que a ela pertencem podem pressupor que outros já estão assumindo o cuidado e o apoio devido e, no final, nenhum acaba por atuar de forma efetiva.

Nesse sentido, ao analisar a composição da rede, a representação gráfica dos mapas, possibilitou a visualização da presença ou não de pessoas e instituições nas relações com os adolescentes em LA. Assim, na análise do conjunto dos mapas dos 26 adolescentes em LA (Apêndice F), a família, o CREAS, na figura dos profissionais psicólogos e assistente social, e os amigos sobressaíram-se, ao passo que a escola e o trabalho tiveram pouca expressividade. A comunidade e os serviços de saúde não compuseram os mapas sociais desses adolescentes, conforme apresenta a Tabela 3. 
Tabela 3 - Número de adolescentes em liberdade assistida segundo os quadrantes e membros referidos nos mapas de redes sociais. Patos de Minas, MG, Brasil, 2014. $(\mathrm{n}=26)$

\begin{tabular}{lc}
\hline Quadrantes/membros & $\mathrm{N}^{\circ}$ de adolescentes \\
\hline Família & 26 \\
Agências sociais/ psicólogo, assistente social, professor do CREAS & 20 \\
Amizades/ amigos, namorado (a), Deus & 16 \\
Escola/ colegas de escola, professores, namorado (a) & 14 \\
Trabalho/ colegas de trabalho e patrão & 05 \\
Comunidade & - \\
Serviços de saúde & - \\
\hline
\end{tabular}

Os resultados acerca da distribuição dos elementos pelos quadrantes corroboram a literatura, uma vez que há estudos apontando efetivamente que as famílias e seus membros e os amigos, são as figuras mais importantes nas redes sociais (GOSWAMI, 2011). Essa relação com os amigos tem também influência no comportamento dos adolescentes, como os próprios participantes do estudo referiram, mas não apenas de forma negativa.

Branco; Wagner (2009) acrescentam por meio dos dados de um estudo com adolescentes em conflito com a lei, que praticamente todos os adolescentes falaram da influência dos amigos na iniciativa do ato infracional.

Chamou a atenção o aparecimento expressivo do CREAS como componente das redes sociais dos adolescentes. Isso demonstra o papel essencial que esse membro institucional tem assumido na vida dos adolescentes, ao mesmo tempo em que ilustra como um instrumento formal do Estado pode ser significado de forma afetiva e diferente pelas pessoas que fazem seu uso, levando-as a fortalecer sua rede social, prevenindo a recidiva do ato infracional.

Entende-se como grave a ausência de membros da comunidade e dos serviços de saúde na rede social dos adolescentes. Para Goswami (2011), tanto a comunidade quanto os serviços de saúde podem contribuir para que os adolescentes adotem comportamentos positivos, pois propiciam experiências de pertencimento social. No caso estudado, esses quadrantes indicam sentidos explícitos de que não existe vínculo dos adolescentes com os recursos sociais e com as pessoas presentes no cotidiano próximos às suas casas, como, por exemplo, os profissionais da atenção básica a saúde e os vizinhos.

Já nas relações de intimidades, ou seja, de proximidade, destacou-se a figura da mãe, citada pela maioria dos adolescentes, seguida pelos amigos, irmãos, CREAS, psicólogos e o pai. A figura de outros familiares, colegas de escola e de trabalho não teve expressividade. 
Tabela 4 - Frequência dos membros da rede social dos adolescentes em liberdade assistida enquanto relação intima na rede social. Patos de Minas, MG, Brasil, 2014. (n=26)

\begin{tabular}{lc}
\hline \multicolumn{1}{c}{ Relações íntimas } & $\mathbf{N}^{\mathbf{0}}$ de ocorrência \\
\hline Mãe & 23 \\
Amigos & 13 \\
CREAS & 11 \\
Psicólogo (CREAS) & 10 \\
Irmãos (a) & 10 \\
Pai & 09 \\
Avó & 07 \\
Colega de escola & 07 \\
Namorado (a) & 06 \\
Tio(a) & 05 \\
Professor (a) & 04 \\
Patrão & 03 \\
Colega de trabalho & 02 \\
Primo & 01 \\
Padrasto & 01 \\
Assistente Social (CREAS) & 01 \\
Professor de violão (CREAS) & 01 \\
Madrasta & 01 \\
Deus & 01 \\
Madrinha & 01 \\
\hline
\end{tabular}

Já nas relações sociais, chama atenção a presença do pai e da mãe. O pai também aparece nas relações com conhecidos, conforme mostra a Tabela 5. Isso é preocupante, pois nesse âmbito relacional, espera-se encontrar pessoas ou instituições que possuam menos contato e menor nível de compromisso com os adolescentes.

Tabela 5- Frequência dos membros da rede social dos adolescentes em liberdade assistida enquanto relações sociais e com conhecidos na rede social. Patos de Minas, MG, Brasil, 2014. $(n=26)$

\begin{tabular}{|c|c|}
\hline Relações sociais & $\mathrm{N}^{0}$ de ocorrência \\
\hline 5 & 05 \\
\hline Primo & 03 \\
\hline Tio (a) & 03 \\
\hline Irmãos (a) & 03 \\
\hline Mãe & 02 \\
\hline Psicólogo (CREAS) & 02 \\
\hline Namorado(a) & 01 \\
\hline Padrasto & 01 \\
\hline Relações com conhecidos & $\mathbf{N}^{0}$ de ocorrência \\
\hline Pai & 04 \\
\hline Tio (a) & 03 \\
\hline Irmãos & 03 \\
\hline Professor (a) & 01 \\
\hline
\end{tabular}

Em síntese, na análise da composição da rede social, percebeu-se ausência da figura do pai na composição de oito mapas (Amizade, Branco, Cachaça, Capoeira, 
Moreninha, Namorador, Piercing, Tean Sangon). Três foram os principais motivos: ou o pai morava em outra cidade, ou havia falecido, ou não mantinha contato com o adolescente. Também se identificou uma situação em que a mãe abandonou o adolescente (Branquinha) ainda criança e outra em que o adolescente (Cantora) mantinha uma relação rompida com a mãe.

Como se pode observar, os vínculos significativos estão mais diretamente relacionados às mães, sendo os pais menos referenciados. A esse respeito, Feijó; Assis (2004); Nardi (2010) e Nardi; Dell'aglio (2012), mostram que, embora não haja consenso sobre o tema, a ausência ou a não participação do pai na vida do adolescente pode desencadear baixaestima e envolvimento deste com atos infracionais, uma vez que os pais têm papel relevante na construção da subjetividade e no comportamento do adolescente. Conforme os autores, no contexto familiar a figura do pai exerce uma função complexa, sendo essencial para a transposição das questões da dimensão individual para o espaço da coletividade em que pese o convívio social e as relações de autoridade.

Sena, Machado e Coelho (2007) ao analisarem a função paterna e suas relações com os adolescentes que cometem atos infracionais, verificaram que suas relações familiares são marcadas por crises e conflitos, muitos gerados pela ausência da figura paterna. Nessa perspectiva, entende-se que a ausência da figura paterna nas redes dos adolescentes interfere na construção da cidadania, uma vez que os pais precisam desempenhar, em suas vidas, uma função de apoio, seja este de materiais e de serviços, de conselhos e de regulação social e emocional. Quando o adolescente encontra-se em conflito com a lei, o apoio ou a falta de apoio do pai, também, pode determinar a demanda do adolescente por serviços e políticas que sejam capazes de suprir essa ausência, o que pode ser associado a forte formação de vínculos com os profissionais do CREAS, por exemplo. Nesse sentido, Branco, Wagner e Demarchi (2008) pontuam que instituições como o CREAS podem auxiliar não só no resgate da figura paterna, mas também na melhoria do funcionamento familiar dos adolescentes e na ampliação de suas redes sociais.

Na análise da densidade, ou seja, da conexão e qualidade da relação entre os membros, visualiza-se o atributo de intensidade dos vínculos entre os membros da rede social e os adolescentes em LA. Assim, percebem-se vínculos significativos, fragilizados e/ou rompidos. Lembrando que os vínculos significativos são as relações de confiança e amizade caracterizadas por solidariedade, reciprocidade e intimidade; são as pessoas com quem compartilhamos nossas angústias, dúvidas, incertezas, sofrimentos e alegrias. Nesse contexto, 
encontram-se apoio e acolhimento. Nessa análise, observou-se a presença de vínculos significativos, principalmente da figura da mãe, do psicólogo, dos irmãos, da instituição CREAS, do pai e da avó. Além de vínculos com outros familiares, amigos, professor (a), patrão, padrasto, assistente social, madrasta, Deus e madrinha (Tabela 6).

Tabela 6 - Frequência dos membros com vínculos significativos na rede social dos adolescentes em liberdade assistida. Patos de Minas, MG, Brasil, 2014. (n=26)

\begin{tabular}{lc}
\hline \multicolumn{1}{c}{ Vínculos significativos } & $\mathbf{N}^{\mathbf{0}}$ de ocorrência \\
\hline Mãe & 22 \\
Psicólogo (CREAS) & 12 \\
Irmãos (a) & 12 \\
CREAS & 11 \\
Pai & 09 \\
Avó & 07 \\
Tio (a) & 05 \\
Namorado (a) & 03 \\
Amigo (a) & 03 \\
Professor (a) & 01 \\
Professor de violão (CREAS) & 01 \\
Patrão & 01 \\
Padrasto & 01 \\
Assistente Social (CREAS) & 01 \\
Madrasta & 01 \\
Deus & 01 \\
Prima & 01 \\
Madrinha & 01 \\
\hline
\end{tabular}

Pode-se inferir, também, que para os adolescentes há uma percepção positiva do serviço oferecido pelos técnicos do CREAS. Estes oferecem apoio, estabelecem vínculo, garantindo o caráter multidimensional que os vínculos devem assumir nas redes sociais (UDE; FELIZARDO JUNIOR, 2009; WESTRUPP, 2010; TOMÉ et al., 2012). Cabe destacar que, na rede social, os vínculos positivos e as relações interpessoais são essenciais para o desenvolvimento saudável, a resiliência e a socialização dos adolescentes, constituindo-se em fatores de proteção e possibilidade de não envolvimento com atos infracionais (AMPARO, et al., 2008).

Na Tabela 7, a seguir, observa-se fragilidade das relações dos adolescentes em LA com amigos, pai, tios, colegas de escola, outros familiares, namorada, professor (a), patrão, colegas de trabalho e a mãe. Nas relações com vínculo rompido, os dois adolescentes Igreja e Lagoa verbalizaram rompimento de vínculo com seu pai, já, Cantora, relata rompimento de relação com sua mãe. Isso é relevante, pois mostra a distância afetiva com membros que poderiam apoiá-los em sua vida diária no sentido de uma vida saudável. 
Tabela 7 - Frequência dos membros com vínculos fragilizados e rompidos na rede social dos adolescentes em liberdade assistida. Patos de Minas, MG, Brasil, 2014. (n=26)

\begin{tabular}{lc}
\hline \multicolumn{1}{c}{ Vínculos fragilizados } & $\mathbf{N}^{\mathbf{0}}$ de ocorrência \\
\hline Amigos & 10 \\
Pai & 07 \\
Colega de escola & 07 \\
Tio(a) & 06 \\
Irmãos (a) & 04 \\
Namorado (a) & 04 \\
Professor (a) & 04 \\
Primos & 03 \\
Mãe & 02 \\
Patrão & 02 \\
Colega de trabalho & 02 \\
Padrasto & 01 \\
\hline Vínculos rompidos & $\mathbf{N}^{\mathbf{0}}$ de ocorrência \\
\hline Pai & 02 \\
Mãe & 01 \\
\hline
\end{tabular}

É válido lembrar que os vínculos rompidos são constituídos de relações rompidas devido a alguma decepção séria, traição, incompatibilidade ou alguma situação de violência que gerou afastamento entre as pessoas, ao ponto de quebrar seus vínculos sociais e institucionais. Por outro lado, também representam indivíduos que pertencem à rede social, porém, devido a falta de oportunidade de contatos, não estabelecem relações.

Por sua vez, na análise da dispersão, ou seja, da acessibilidade entre os membros, observou-se acesso semanal aos serviços do CREAS e contato diário com os membros das relações íntimas. A maioria dos adolescentes relatou dificuldade em chegar ao CREAS, devido à distância geográfica, pois o CREAS está localizado no centro do município de Patos de Minas enquanto a maioria dos adolescentes reside na periferia. Porém, verificou-se nas falas dos adolescentes que o acesso ao CREAS é facilitado pela ajuda financeira da instituição em forma de vale transporte.

$\mathrm{Na}$ análise da homogeneidade e heterogeneidade demográfica e sóciocultural, ou seja, idade, sexo, cultura e nível sócio econômico dos membros da rede social dos adolescentes, observou-se certo padrão nos aspectos socioeconômico e cultural dos membros da rede. No quesito idade e sexo, predominaram adultos na faixa etária de 25 a 40 anos bem como crianças de até 12 anos. Houve predomínio de membros do sexo feminino, sobretudo na figura da mãe, irmãs, tias, avós, amigas e madrastas. Em relação ao nível educacional, a maioria dos membros da rede possuía apenas o ensino fundamental incompleto. Em relação a renda mensal, esta variou entre um a dois salários mínimos. 
Nesse sentido, verifica-se a necessidade de realizar entrevistas com cada membro da rede social dos adolescentes, com o intuito de elencar mais informações sobre a dispersão, homogeneidade, heterogeneidade e mesmo a reciprocidade do tipo de vínculo, aspectos que não foram contemplados nos objetivos desse estudo.

Ao analisar á funções dos vínculos das redes dos adolescentes, entendendo que esta dimensão se refere à oferta de apoio em um nível funcional, identificou-se que as relações proximais, ou seja, aquelas em que são protagonistas familiares e pessoas próximas, são as que mais ofereceram algum tipo de apoio aos adolescentes, como se observa no Quadro 1 .

Quadro 1 - Membros da rede social dos adolescentes em liberdade assistida segundo o tipo de função exercida na rede social. Patos de Minas, MG, Brasil, 2014.

\begin{tabular}{|l|l|}
\hline Membros da rede social /N $\mathbf{N}^{\mathbf{0}}$ de ocorrências & Tipo de função da rede social \\
\hline Família/26 & Apoio emocional \\
Mãe/25 & Ajuda material e de serviços \\
Pai/ 18 & Guia cognitivo e de conselhos \\
Irmãos/10 & Regulação e controle social \\
Avó /7 & \\
Tia (o)/5 & \\
Primo/1 & \\
Namorado (a)/3 & \\
Padrasto/2 & \\
Madrasta/1 & \\
Madrinha /1 & \\
\hline Agências sociais /20 \\
Psicólogo do CREAS/12 & Apoio emocional \\
CREAS/ 11 & Ajuda material e de serviços \\
Assistente social do CREAS/ 1 & Guia cognitivo e de conselhos \\
Professor de violão/ CREAS/1 & Regulação e controle social \\
\hline Amizades/16 & Acesso a novos contatos \\
Amigos/ 13 & Apoio emocional \\
Namorado (a) / 2 & Companhia social \\
Deus/1 & \\
\hline Escola/ 14 & \\
Colega de escola/ 7 & Guia cognitivo e de conselhos \\
Professores/ 5 & Regulação e controle social \\
Namorado (a) /2 & \\
\hline Trabalho/5 & Regulação e controle social \\
Patrão/ 3 & \\
Colega de trabalho/2 & \\
\hline
\end{tabular}

Notou-se que nas figuras familiares, a mãe sobressaiu-se como a que mais oferece apoio, aparecendo nas funções de ajuda material e de serviços, guia cognitivo e de conselhos, apoio emocional e regulação e controle social. O CREAS também apareceu como instituição que desenvolve todas estas funções e associa ainda a função de possibilitar a acessos a novos 
contatos. Já os amigos aparecem desempenhando as funções de companhia social e apoio emocional. A escola e o trabalho aparecem de forma menos expressiva. A escola desempenhando as funções de guia cognitivo e de conselhos, regulação e controle social, ao passo que as relações de trabalho assumiram o papel de regulação e controle social de forma menos expressiva. Não aparecem membros da comunidade tampouco profissionais dos serviços de saúde ou outras instituições nas redes dos adolescentes.

Os desenhos das redes apontam para pontos essenciais que devem ser fortalecidos para se converterem em fatores de proteção contra a criminalidade, evitando-se o envolvimento ou a recidiva em atos infracionais.

$\mathrm{O}$ processo adolescer depende das experiências positivas com figuras significativas que respondem às necessidades pessoais, materiais, afetivas e sociais (MOTA; MATOS, 2008). Dessa forma, quando uma instituição compõe a rede social de um adolescente, ela tem que garantir diferentes funções na rede, promovendo de forma segura o desenvolvimento do sujeito ao passo que oferece diferentes tipos de apoio. A literatura indica a extrema importância de as instituições que prestam serviços à criança e ao adolescente terem adultos que se vinculam, de forma positiva, com os sujeitos atendidos. Os técnicos e profissionais dessas instituições assumem um papel central nas redes sociais e podem ser fatores protetivos para o desenvolvimento e a saúde dos adolescentes (MARTINS, 2004; MOTA; MATOS, 2008; SIQUEIRA; DELL'ALGIO, 2010; MENDES; 2011), o que mostrou a análise deste estudo em relação ao CREAS. Esses aspectos serão mais explorados adiante, neste estudo.

Em síntese, ao analisar os atributos da rede social desses adolescentes, percebese que as redes sociais dos adolescentes em LA participantes deste estudo apresentam tamanho reduzido, com uma distribuição de membros de forma irregular, com uma maior concentração nas relações íntimas com familiares e com a agência social (CREAS). Existe uma ausência de membros dos serviços de saúde, da educação e da comunidade na rede social desses adolescentes. Em relação às funções, notou-se uma dinamicidade e um multidimensionamento do papel dos membros da rede social.

$\mathrm{Na}$ função de ajuda material, destacaram-se os membros da família e o CREAS. No apoio emocional, destacaram-se a família, especialmente a mãe, os amigos e o CREAS. Na função de guia cognitivo e de conselhos, destacaram-se a família, os professores e o CREAS. Na regulação e no controle social, também apareceu a família, o CREAS, de forma menos expressiva, apareceram os colegas de trabalho e de escola. Na função de companhia 
social, apenas os amigos são referenciados ao passo que na função de propiciar acesso a novos contatos, apenas o CREAS foi referenciado.

No geral, os vínculos mais significativos foram com os membros da família, na figura da mãe, da avó, dos irmãos e do pai. Ademais, os psicólogos e o CREAS foram referenciados. Nos vínculos fragilizados, foram referenciados alguns amigos, o pai, o tio, os colegas de trabalho. Nos vínculos rompidos ou inexistentes, apareceram o pai e a mãe. Assim, pode-se afirmar que a relação íntima e positiva dos adolescentes em LA e os membros da família, do CREAS, da escola e do trabalho é fonte protetora.

Por fim, pode-se afirmar que a análise das redes sociais de adolescentes em cumprimento de LA contribui para a compreensão de sua história de vida e seu envolvimento com atos infracionais. Para aprofundar essas questões, a seguir, exploram-se os quatro núcleos de sentido.

\subsection{DESCRIÇÕES DOS NÚCLEOS TEMÁTICOS}

Neste item serão descritos os quatros núcleos de sentidos que foram construídos a partir dos dados coletados nas entrevistas com os adolescentes em LA e nos mapas de rede construídos por eles. Lembrando que os núcleos que emergiram a partir desta análise foram: 1) serviços e engajamento social, 2) membros da rede social: destaque para figuras femininas 3) a essencialidade da rede social e 4) processo de adolescer e cumprimento da LA. A seguir, focaliza-se o primeiro núcleo temático.

\subsubsection{Serviços e engajamento social}

Neste núcleo serão descritas análises sobre as relações dos adolescentes e os serviços e ou instituições sociais que compõem sua rede social, como o CREAS, a escola, a igreja e programas de incentivo à inserção profissional.

Inicialmente, destacou-se o apoio que os adolescentes em LA recebiam dos técnicos e profissionais do CREAS. De maneira positiva, a equipe do CREAS é um elemento presente nos discursos e na maneira como esses adolescentes relatam sua experiência no serviço de proteção. Eles afirmaram receber conselhos, carinho, atenção e apoio dos profissionais. O Centro também foi indicado como local de descobertas, orientação e 
aprendizagens, com a difusão de exemplos positivos e que podem mudar sua história e seus projetos de vida, como se observa nas falas a seguir:

(...) antes eu era ruim na escola, agora eles (profissionais do CREAS) estão me ajudando a subir mais na vida. (Capoeira)

(Os profissionais) dão carinho e atenção. Conversam, orientam... Isso aí. Bem, acho bom aqui no CREAS. Tem aula de teatro... É legal. (Dança)

A minha ligação com as pessoas aqui no CREAS é forte; eles me dão atenção. (Lagoa)

Eu tive oportunidades que eu nunca teria se eu não tivesse começado aqui (no CREAS). Eu descobri uma coisa que eu adorava que é desenhar... Hoje eu desenho assim e eu penso: "se não tivesse vindo pra cá, não teria essa oportunidade". Ela (a psicóloga) me mandou para a hidroginástica... Também foi muito bom pra mim. Academia também eu participei. Foi muito bom. Aí então o cumprimento da medida foi mais a diversão; eu descobri coisas que eu gostava e que me favoreciam. (Moda)

O CREAS oferece a oportunidade de o adolescente circular pela cidade, utilizando a sua liberdade, ou seja, a possibilidade de conhecer uma nova opção de vida que não seja a do ato infracional. Nesse sentido, é importante que a cidade ofereça uma rede assistencial a esses adolescentes, englobando aspectos com saúde, educação, cultura, lazer. O CREAS também é percebido como local que "afasta das coisas ruins" e que preenche o tempo livre com atividades diversificadas. Nesse sentido, ganham destaque, por exemplo, as ações de combate ao uso de drogas e a necessidade de se observar as leis e regras sociais. As falas a seguir corroboram essa análise:

Gosto de vir aqui (CREAS), porque como não tem nada pra fazer em casa, acho melhor, porque aqui (...) é um passatempo pra mim, eu aprendo mais coisas, tenho mais coisas no currículo, aí melhorou pra mim. (Branquinha)

Aqui tem coisa pra eu fazer. Eu converso, faço amizade de novo, faço curso de violão, dança... (Piercing)

(O CREAS) ajuda a tratar e dar solução aos adolescentes nesta situação (Liberdade Assistida). Aqui ajuda muito, ensina o certo e o errado. (Dança)

(O CREAS) ajuda a seguir as leis, nunca ir com má companhia nem coisas erradas, não entrar no mundo do crime, fazer o bem. (Motorista)

Pode se inferir que para esses adolescentes é importante ter um local como o CREAS. Todavia, seis adolescentes (Cachaça, Companheiro, Igreja, Namorador, Tímido, Moreno), apontaram dificuldades de acesso a essa instituição, visto esta estar localizada em região central e os adolescentes residirem em áreas periféricas da cidade. 
Só que (o CREAS) é um bocadinho longe, aí complica um pouco né. Tem hora que chego atrasado. (Namorador)

O CREAS é distante da minha casa, ás vezes dá preguiça de vir aqui (CREAS).(Cachaça)

O CREAS é muito distante, longe mesmo, aí dá preguiça de vir. (Companheiro)

A minha casa é muito longe daqui $(C R E A S)$, mas eu ganho um cartão de vale transporte. (Moreno)

Eu moro lá (bairro na área periférica da cidade), se sabe, é longe do CREAS, mas venho assim, mesmo. (Igreja)

Isso caracteriza o aspecto da dispersão, ou seja, a distância geográfica e a acessibilidade aos membros da rede social, as quais podem garantir ou não o estabelecimento de vínculos positivos e significativos. Visando sanar essa dificuldade, o CREAS oferece apoio financeiro para custear as passagens de ônibus para o local, o que minimiza as dificuldades de acesso do adolescente a esse serviço:

Gosto de vir aqui. Isso me ajuda e eu ganho até o ônibus para vir. (...) Às vezes tenho preguiça, mas minha mãe me manda vir. (Moreninha)

Eu venho para cá (CREAS), toda semana de ônibus, o CREAS da à passagem. (Moda)

No tocante aos sentimentos manifestos pelos adolescentes em relação ao CREAS, identificou-se uma prevalência de sentimentos positivos, de bem-estar, de conforto, de que se estava "pagando" ou "quitando" uma dívida com a sociedade:

A ajuda (recebida no CREAS) me faz sentir bem e sentir feliz com as pessoas que me dão carinho. (Amizade)

Me sinto bem. Ótimo. Eu estou sendo acompanhado pelo psicólogo, assistente social para melhorar a minha vida. (Futebol)

É bom, porque eu aprendo várias coisas. É legal até conversar com o psicólogo. (Branquinha)

Eu sinto que eu estou pagando o que eu fiz, porque eu fiz uma coisa errada e eu estou pagando por isso. Eu levo como exemplo, sabe, para não fazer de novo. (Lutador)

Ao mesmo tempo, foram identificados sentimentos de adolescentes que achavam ruim estar no CREAS, pois, segundo eles, ou não gostavam de ir à instituição ou poderiam estar fazendo outras coisas: 
Na verdade, não queria estar aqui não. Não queria nem mexer com esses trem ${ }^{4}$ de polícia. Isso petecou (estragou) a minha vida demais... Mas está até sendo bom, porque eu estou aprendendo como é a vida lá fora. Eu não sabia, pra mim era só fazer bagunça mesmo. Agora aprendi que não é não. Tudo tem consequência, tudo na vida tem um preço. (Esporte)

Ainda nesse sentido, mesmo com alguns adolescentes afirmando que não gostariam de frequentar o CREAS, percebe-se que para eles essa instituição é essencial no apoio e na composição da sua rede social, tendo em vista o vínculo significativo com os psicólogos, assistentes sociais, professor de violão e a direção. Isso é revelado por 20 dos 26 adolescentes participantes do estudo. O mapa da rede social de Piercing e Branquinha ilustram essa análise:
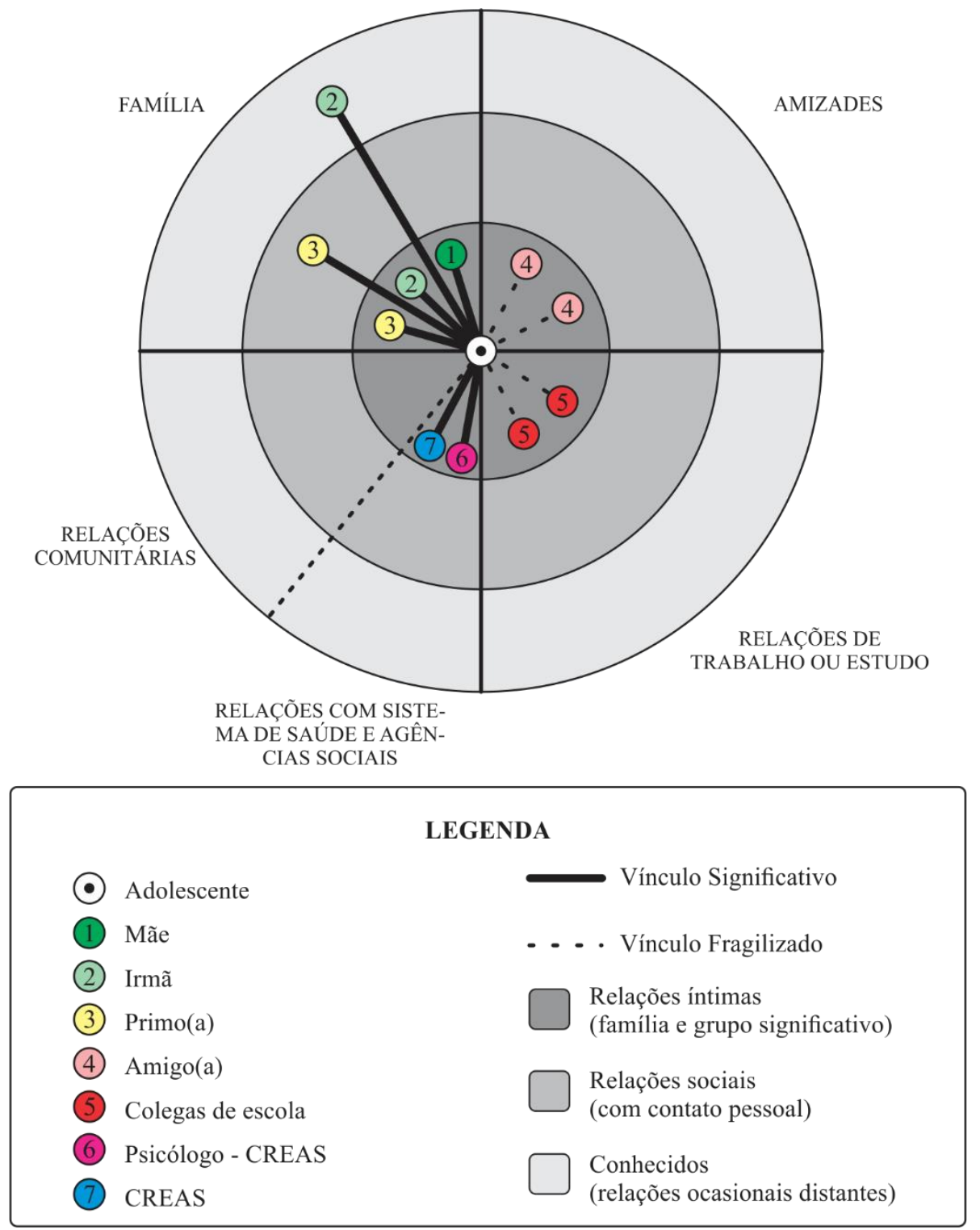

Figura 24 - Mapa de rede social do adolescente em LA - Piercing, 17 anos

\footnotetext{
${ }^{4}$ Gíria utilizada no Estado de Minas Gerais. Significa: coisa, objeto.
} 


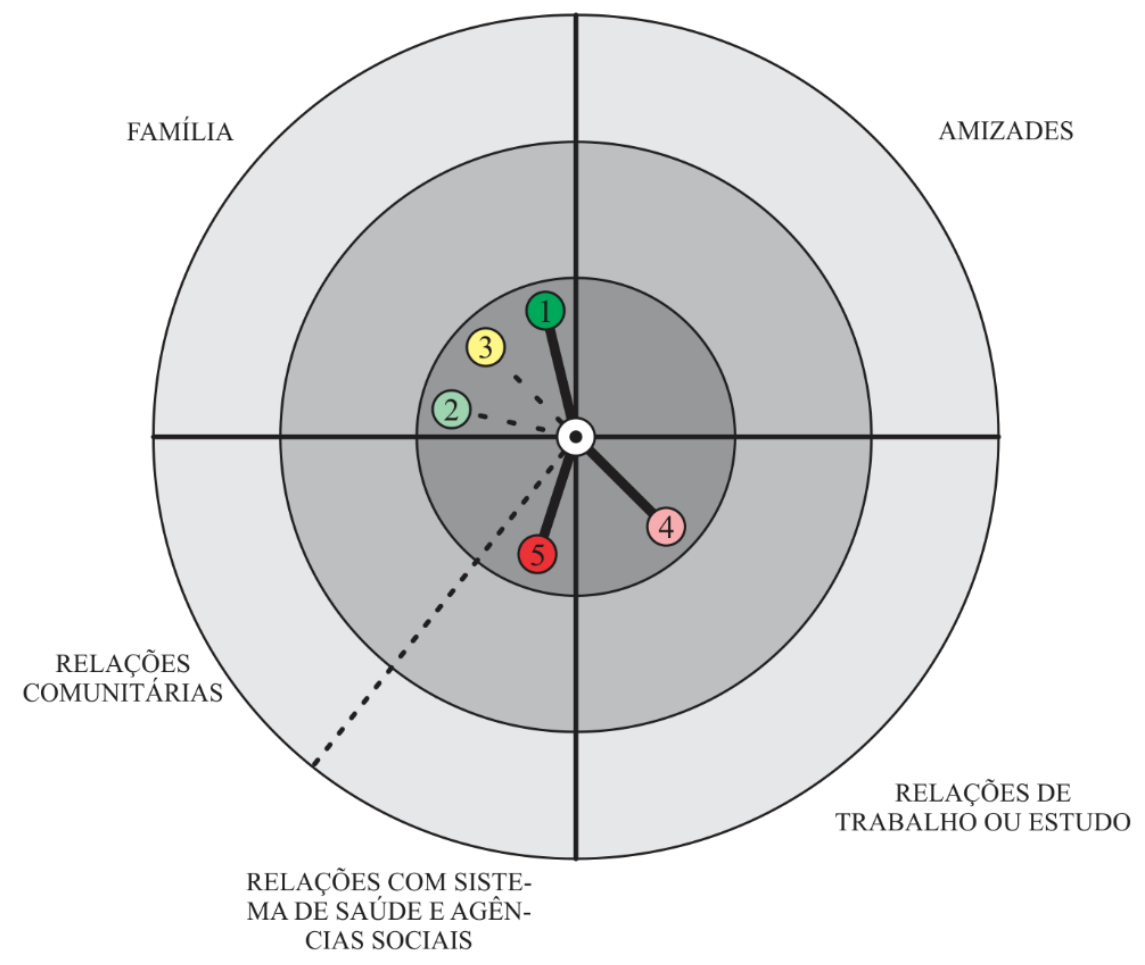

LEGENDA

- Adolescente

(1) Pai

(2) Madrasta

(3) Namorado(a)

(4) Professora de Português

5) Psicólogo-CREAS
Relações íntimas

(família e grupo significativo)

Relações sociais

(com contato pessoal)

Conhecidos

(relações ocasionais distantes)

Vínculo Significativo

- - Vínculo Fragilizado

Figura 6 - Mapa de rede social do adolescente em LA - Branquinha, 16 anos

Pôde-se constatar que os profissionais do CREAS são percebidos pelos adolescentes como fonte de algum tipo de apoio que ultrapassa a própria questão do oferecimento técnico dos serviços de proteção social. Isso mostra que a equipe do CREAS é vista como pessoas significativas para as redes sociais dos adolescentes, percebidos pela maioria deles como importantes e capazes de fornecer algum tipo de apoio.

Além de serem técnicos no serviço eles são figuras adultas, o que para a literatura (SLUZKI, 2006; 2010; ALARCÃO, 2007; MOTA; MATOS, 2008; BRANCO; WAGNER, 2009) é um aspecto relevante a ser considerado, pois o apoio fornecido pelos adultos é geralmente percebido como mais eficaz do que o de outras fontes. Isso pode se dar, em 
alguma medida, pela idealização positiva que os adolescentes podem fazer dessas pessoas em detrimento dos amigos ou grupo de pares, por exemplo.

O fato deles ainda entenderem os profissionais da instituição como prestadores de apoio financeiro pode estar associado a uma perspectiva positiva que eles fazem do próprio CREAS e esse tipo de apoio, muito presente também nas relações familiares. Entretanto, esses profissionais permanecem no campo relacional de agências sociais, o que também chama a atenção, pois eles não são percebidos como amigos ou membros da comunidade.

$\mathrm{O}$ apoio emocional e o material são os que mais aparecem nessa categoria, sendo expressos por situações de atendimento, aconselhamento e regulação da conduta social. No que se refere ao apoio material, destaca-se, conforme já mencionado anteriormente, o apoio financeiro que CREAS oferece aos adolescentes para que se desloquem até a instituição, o que é entendido como apoio financeiro muito importante no cumprimento da medida de LA.

Nessa perspectiva, Davim et al. (2009) e Carmo et al. (2011) pontuam a necessidade de o adolescente ser amparado por uma rede social protetora ampla, composta não apenas da família, mas da comunidade, da sociedade e dos equipamentos do Estado, CREAS, por exemplo. Essa rede, segundo os autores, propicia aos adolescentes condições de enfrentamento e superação de adversidades, bem como seu não envolvimento em situações que possam lhes causar danos e agravos, incluindo o comportamento infracional.

Le Blanc (1997, 2003, 2006), por sua vez, destaca a importância dos mecanismos de vínculos sociais como os reguladores mais estáveis para evitar o envolvimento e mesmo engajamento em atos infracionais. Assim, os vínculos estabelecidos com pessoas e/ou instituições ligadas ao adolescente, a sua rede social, se constituem em fatores de proteção fundamentais contra a prática de atos infracionais, o que pode indicar a relevância de instituições como o CREAS para adolescentes em conflito com a lei e em medida de LA.

Também nessa linha de pensamento, Mota e Matos (2008) destacam que experiências positivas e relações com pessoas significativas para o atendimento de necessidades pessoais, afetivas e sociais de crianças e adolescentes, influenciam no seu processo de adolescer. Dessa forma, as autoras alertam para a importância de um olhar individual e vinculativo de um adulto com crianças e adolescentes. Assim, os profissionais de instituições, como o CREAS, devem trabalhar em uma perspectiva que amplia a questão contratual e institucional para o cumprimento das medidas socioeducativas. Tais instituições devem se configurar como um importante recurso social ou alternativo para complementar a rede social das crianças e dos adolescentes. 
Neste trabalho, a escola também foi citada pelos adolescentes como instituição que poderia ajudá-los a evitar o ato infracional e a mudar sua perspectiva de vida, conforme ilustra os excertos seguintes:

(...) o estudo é tudo (...) porque sem estudo você não pode trabalhar. Igual meu pai, não tem nem a quinta série... Trabalha, mas trabalha a mesma coisa de ser explorado. (...) Na escola a professora (de português) me ajuda quando tenho dificuldade em alguma coisa, até em outras matérias, como o inglês, matemática; ela me ajuda. (Branquinha)

A escola é o futuro da gente, pra quem quer. Tem aqueles brincalhões, que vão só pra avacalhar, agora para quem quer estudar e aprender, (a escola) é o futuro da gente. A escola ajuda demais, explica bem, mas o aluno tem que querer, não adianta ele ir lá. Tem uns que querem e outros que não; fazem um tumulto na sala, entendeu? Eu sou um dos que querem estudar. (Motorista)

O meu professor... Lá (na escola) nós trocamos a maior ideia, falamos um monte de trem, sei lá, acho importante a conversa, o conselho que a gente recebe. (Violão)

Ainda segundo os adolescentes, alguns deslizes cometidos em sua história de vida e na maneira como lidavam com a escola contribuíram para sua atual condição. Ademais, frequentar a escola e obedecer aos pais poderia ajudá-los a não se envolverem com atos infracionais:

Repeti três anos escolares porque eu brinquei; fiz bastante hora na escola. (Branquinha)

Entrevistadora: O que poderia ajudar os adolescentes a não se envolverem com atos infracionais?

Aventura: Não se envolver com os rolos, não ficar envolvido com pessoas erradas, não sair da escola, não desobedecer aos pais.

Pintando um quadro diferente e retratando uma realidade comum para adolescentes que cumprem LA, também se percebeu que algumas experiências na escola não são positivas, mas negativas e relacionadas a situações de preconceito, como ilustra a fala de Igreja:

Na escola é cada um por si... (os colegas) viram a cara pro outro e é isso mesmo... Nem as professoras falam com você direito. (...) Lá eles não são humanos não, eles são ricos, eles podem. A gente que é pobre, que está indo lá porque precisa, eles não dão muita ideia não. (Igreja)

De forma crítica e afirmando a questão da necessidade de regras e normas, os adolescentes também avaliam que, em alguns aspectos, a escola precisa melhorar para que frequentem essa instituição e não cometam atos infracionais. Destacam que a instituição deve adotar regras mais rígidas: 
(...) Eu acho que tinha que colocar mais guardas nas escolas, porque os guardas que existem lá não estão adiantando nada. Colocar mais regras. Os professores não pegam firme também com eles (os adolescentes) dentro da sala; eles fazem o que querem com os professores. (Lagoa)

Nesse sentido, um estudo realizado por James; Bunch; Clay-Warner (2014) salienta a necessidade de a escola se configurar como um ambiente "justo" para o adolescente. Segundo os autores, a percepção dos adolescentes acerca de atos injustos no ambiente escolar pode levá-los a atos de violência. Deve-se, pois, considerar como relevante o ambiente educacional e disciplinar em que os adolescentes em LA estão inseridos.

Ainda no tocante à escola, percebeu-se que os adolescentes apresentaram vínculos de fragilidade com essa instituição, pois poucos referenciaram a escola, tanto nas falas quanto nos desenhos dos mapas. Recorrentemente, a figura de algum professor prevaleceu em relação à instituição escolar, como observado nos mapas dos adolescentes Dança e Lagoa. O primeiro mapa mostra uma relação frágil com uma professora, porém próxima do adolescente, e o segundo mapa colocou a professora distante do adolescente e com vínculo também frágil.

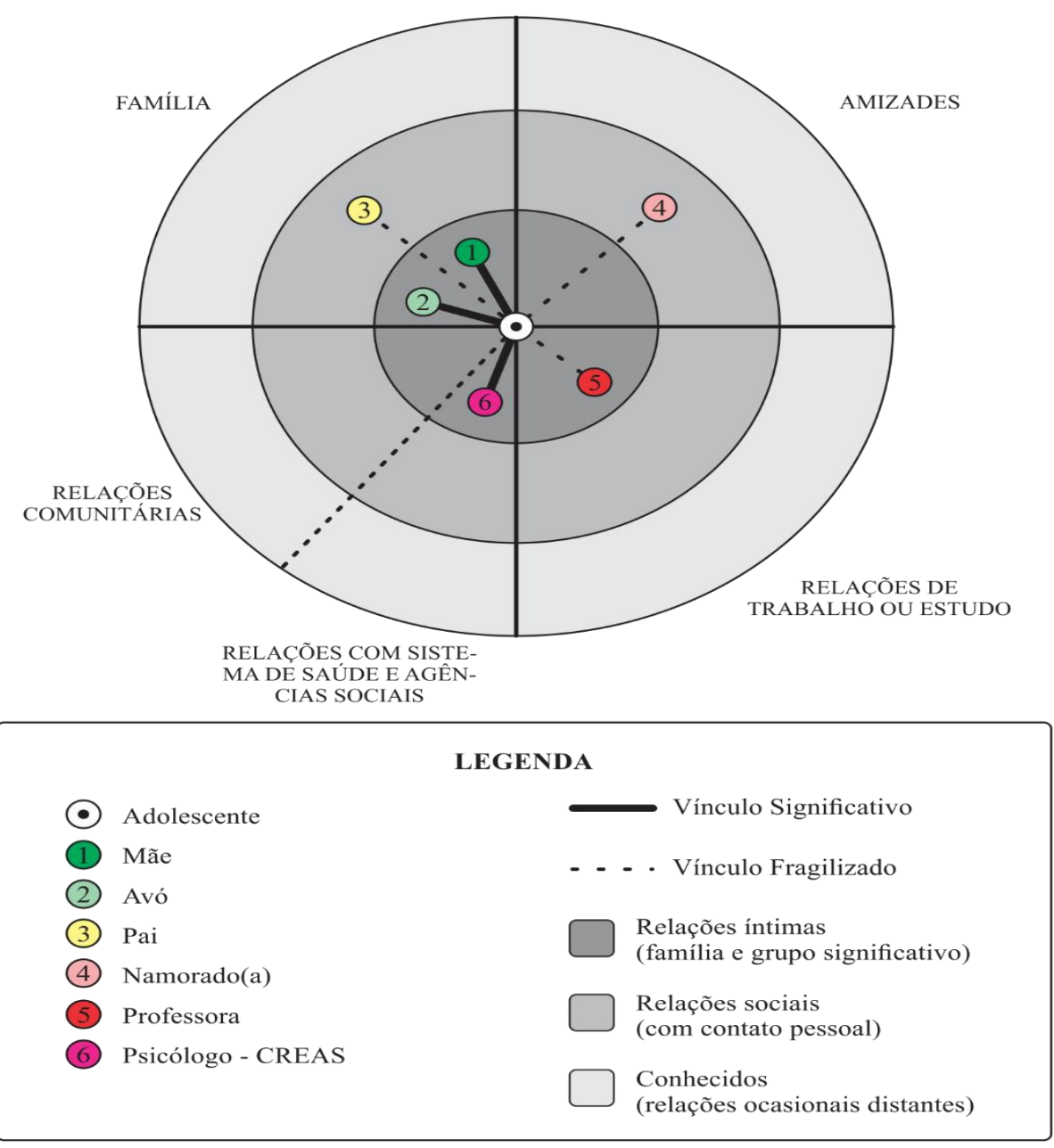

Figura 11- Mapa de rede social do adolescente em LA - Dança, 14 anos 

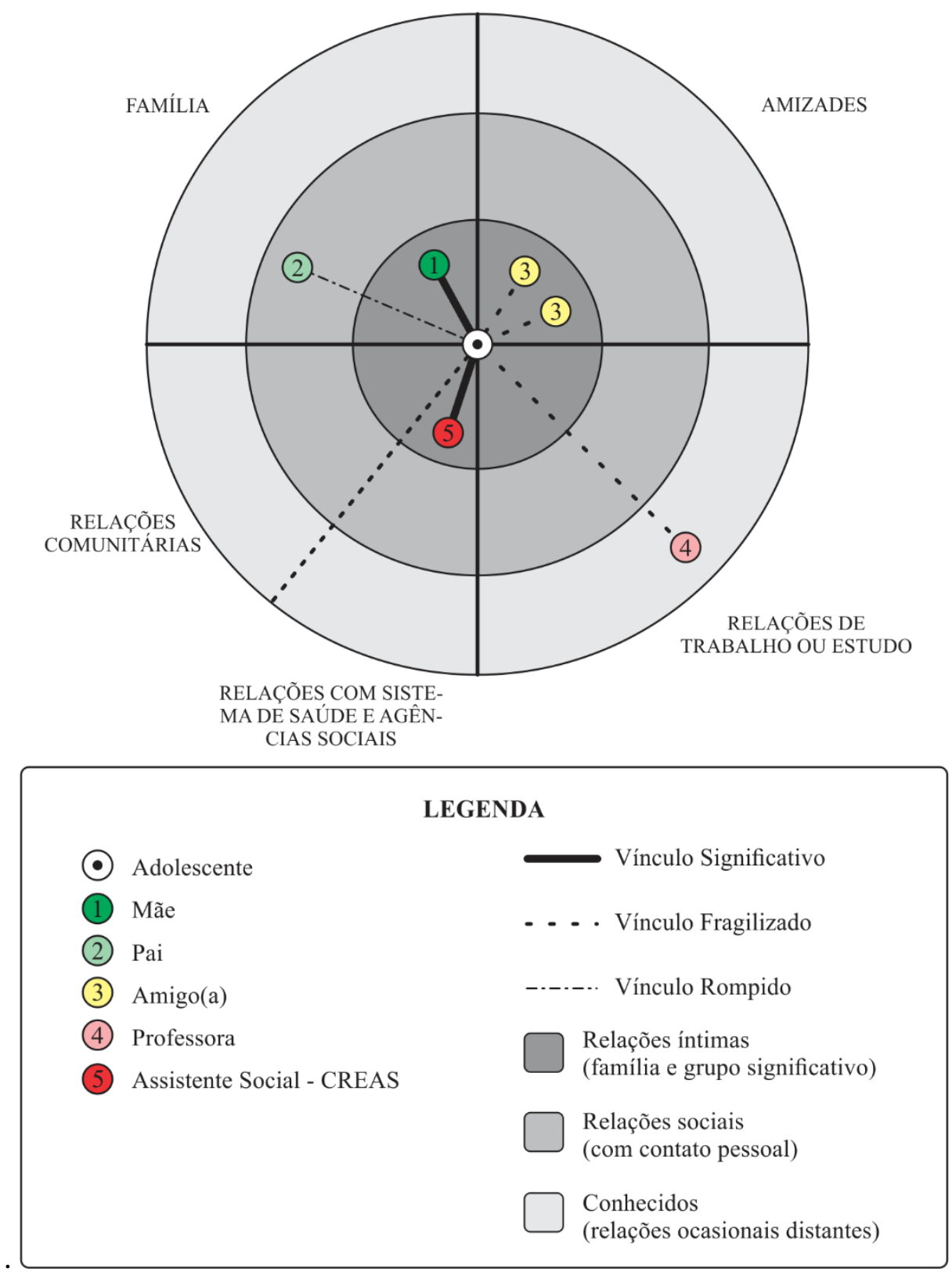

Figura 16 - Mapa de rede social do adolescente em LA - Lagoa, 14 anos

Nos mapas acima, a figura do professor, representando uma relação positiva e de afeto, indica a segurança de ter ajuda ou apoio desse profissional caso seja necessário, não apenas no que se refere ao processo de escolarização, mas também ao apoio na forma de aconselhamento, por exemplo. De acordo com Caldwell; Wiebe; Cleveland (2006), a oferta de ajuda por parte dos professores, nos momentos de dificuldade, é interpretada pelos adolescentes como indicador de interesse e estima em relação a eles, o que é medido pela existência e facilidade de comunicação, diálogo e o oferecimento de conselhos, elogios e incentivos. Essa relação acaba sendo muito importante na constituição das redes sociais dos 
adolescentes que vivem na escola a oportunidade construir vínculos com pessoas que não são necessariamente da família.

Os adolescentes participantes deste estudo precisam e pedem por regras e normas. Percebem a escola como um espaço que não oferece instrumentos para a vida em sociedade, que não possui regras e normas claramente definidas. Nesse sentido, a LA e o CREAS parecem ressurgir em sua vida como possibilidade para restaurar essa dimensão formativa necessária para o processo de adolescer, dentro da própria concepção dos adolescentes, mesmo que para isso tenha ocorrido o envolvimento do adolescente com um ato infracional.

Bazon; Silva; Ferrari (2013) identificou em um estudo com seis adolescentes que cumpriam a medida socioeducativa LA a existência de dois padrões de trajetórias de escolarização. Um primeiro marcado pela descontinuidade na qualidade das vivências escolares, com um período inicial positivo, que se tornava negativo em seguida, e um segundo cuja marca era a continuidade preponderantemente negativa da experiência.

Nesse sentido, entre outros fatores, a experiência escolar negativa se desponta como um dos preditores mais significativos para o envolvimento em atos infracionais na adolescência (ZHANG et al., 2010). Já para Nunes; Andrade; Morais (2013), além da escola, a família também pode influenciar no envolvimento em atos infracionais. Ao mesmo tempo, essas instituições podem oferecer, em termos de rede social e vínculos significativos e fonte de apoio, estratégias que inibam e minimizem as condutas delitivas praticadas pelos adolescentes.

Por outro lado, um adolescente, ao falar da importância de projetos que oferecem atividades de formação profissional, destaca:

Acho que devia ter mais essa coisa de PROMAM $^{5}$, essas coisas pra eles (adolescentes em LA) ocuparem o tempo e ajudarem a sair da rua... Ter mais atividades. (Branco)

Igreja, por sua vez, traz a questão da lei para problematizar a questão da oferta de trabalho para adolescentes e como essa oferta, em relação com a escola, poderia ajudar no não envolvimento com atos infracionais.

Só tem um jeito (pra não se envolver com a criminalidade): a lei tinha que mudar. Não existe outro jeito não. Se essa lei continua desse jeito não vai pra frente não... A lei do menor, ela tinha que diminuir a menoridade, porque senão não vai pra frente não, porque tem muita gente de menor que não quer ir pro crime; eles querem trabalhar, querem ser alguém na vida, querem ter a chance de crescer... Então nós

\footnotetext{
${ }^{5}$ Trata-se de um programa do município de Patos de Minas, o qual tem por objetivo a promoção da criança e do adolescente.
} 
temos que ir pra escola, mas na escola a gente sofre muito preconceito de muita coisa. Aquilo ali a gente acaba não indo, fica estranho, sua cabeça vai mudando, então acaba que se vai pro mundo do crime. (Igreja)

Igreja também destacou que a falta de condições financeiras, seja dos adolescentes ou de suas famílias, contribui para o envolvimento com a criminalidade. Em suas palavras:

Eu acredito que muitos adolescentes entram nessa vida por falta dum emprego, uma renda, um trem assim, porque igual aconteceu comigo, eu garanto que acontece com todo mundo, por exemplo. (...) nós morávamos no bairro do Cristo, então nós mudamos pro Coração Eucarístico. Cheguei lá, eu vi muita coisa. Eu vi o povo andando de carro, de moto, tinha dinheiro. Então aquilo ali vai puxando a gente... A gente também quer, a gente fica ambicioso, se é de menor, se não pode trabalhar, então a gente vai e escolhe esse caminho (...)se (a família) não tem condição de dar as coisas, você vê todo mundo andando bem vestido, você também quer... Eu acredito que é isso que puxa a gente pro crime. (Igreja)

A questão do trabalho e da renda, forte nessa fala do adolescente como uma das justificativas para o ingresso na criminalidade, possui estreita relação com a organização da sociedade capitalista em que vivemos e com a maneira como a maioria das comunidades vive a questão do consumo estimulado, sobretudo, pela mídia. Todavia, não se pode considerar esta a única justificativa, mas ela deve ser considerada quando se procura entender o que leva os adolescentes a se envolverem cada vez mais com a criminalidade.

Nesse sentido, um estudo que investigou a influência e o significado do trabalho na vida dos adolescentes em LA em relação a suas relações familiares constatou:

(...) uma ressignificação das relações familiares de cada adolescente a partir de sua experiência de trabalho, pois todos relataram mudanças significativas nas relações estabelecidas com a família depois que começaram a trabalhar, principalmente no que se refere à confiança da família em relação a eles. $\mathrm{O}$ trabalho não apresenta um sentido organizacional ou social, não leva os adolescentes a uma condição de autonomia, mas existe um sentido individual inequívoco para a atividade na qual estão engajados: a ressignificação de sua inserção social e familiar, além de promover outra colocação frente a sua inclusão no sistema judicial (JACOBINA; COSTA, 2007, p. 95).

Já no mapa a seguir, percebe-se a inserção da figura do patrão como elemento pertencente à rede e fonte de algum tipo de apoio para o adolescente Namorador: 

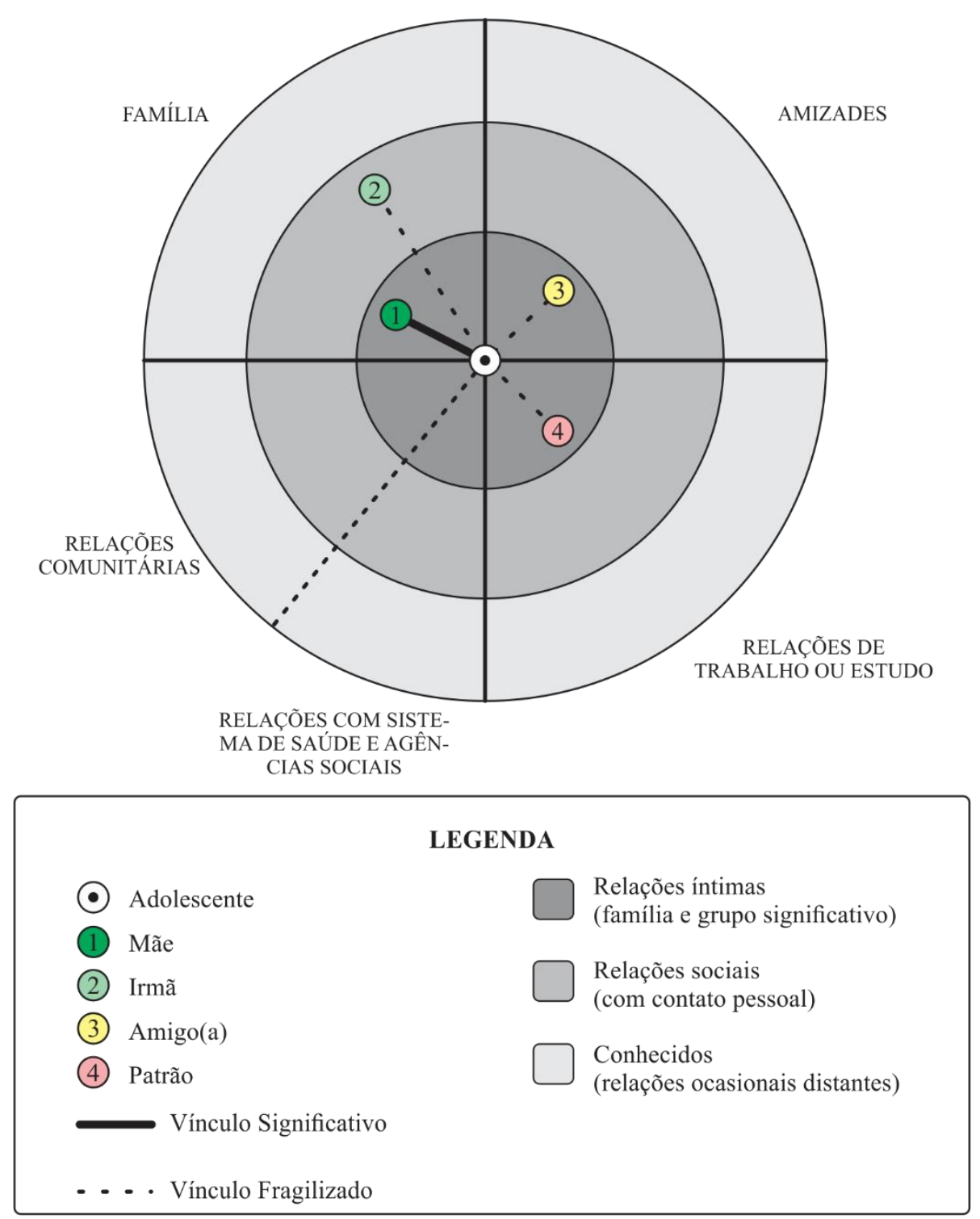

Figura 22 - Mapa de rede social do adolescente em LA - Namorador, 17 anos

Ainda nesse tocante, Castel (2008) considera o trabalho uma referência econômica, psicológica, cultural e simbólica na estruturação da existência dos sujeitos. Segundo o autor, por meio do trabalho, o sujeito estabelece vínculos com grupos familiares e sociais, o que desencadeia o sentimento de pertença a uma determinada comunidade, ou seja, a inserção relacional. Essa inserção relacional tende a diminuir as situações de vulnerabilidade e aproxima as pessoas umas das outras em termos de vínculos nas redes sociais, o que é positivo e protetivo para a saúde e o desenvolvimento humano.

Jacobina; Costa (2007) também discutem a importância da inserção do adolescente no mercado de trabalho. Para as autoras, o trabalho é um elemento capaz de alterar a percepção da família em relação ao adolescente, por possuir a característica de afastá-lo de situações de vulnerabilidade. Costa e Alípio (2010) acrescentam que, a partir do 
trabalho, o adolescente em conflito com a lei sente-se valorizado pelas várias esferas que o circunda: escola, comunidade, família. Assim, o trabalho propicia ao adolescente livrar-se do estigma de autor de atos infracionais, dando sentido e construindo um projeto de vida diferente daquele experienciado quando da prática de atos infracionais. Enfim, o trabalho pode propiciar ao adolescente a desconstrução de uma possível identidade marginal.

A igreja também aparece como espaço essencial para ressignificar a história de vida dos adolescentes. De acordo com os dados, ela é um espaço de engajamento social que também contribui na inserção dos adolescentes na sociedade e que, de certa forma, oferece regras e normas que os apoiam, como resumiu Esporte:

\begin{abstract}
Eu vou à igreja. Eles estão me ajudando demais. Na verdade, esses dias pra trás eu estava conversando com o pastor lá... Deus quer me ajudar, já me tirou da morte várias vezes... Se não fosse Deus, eu estava era morto... Não sei... Não foi por causa de doença não, foi o povo mesmo, inveja... Já andei com esse povo do tráfico, aí parei de andar... Eles se sentem traídos, a gente fica marcado... Mas graças a Deus agora eu não tenho medo não, já usei droga, maconha... Controlei graças a Deus. (Esporte)
\end{abstract}

A presença da religiosidade e de Deus também chama a atenção no desenho dos mapas, pois, em geral, quando aparece, ela tem vínculo forte e ocupa lugar no espaço destinado aos amigos, como no mapa do adolescente Festa.

Comumente a igreja é um membro referido em pesquisas que investigam sobre mapas de redes sociais, independentemente do grupo pesquisado. Em geral, esse movimento é explicado pela busca das pessoas por espaços alternativos para enfrentarem problemas relacionados a vida em sociedade, aos conflitos e a saúde, demonstrando a relevância depositada no papel da religião como complemento para os diferentes tipos de serviços e políticas públicas (ALEXANDRE et al. 2012). 


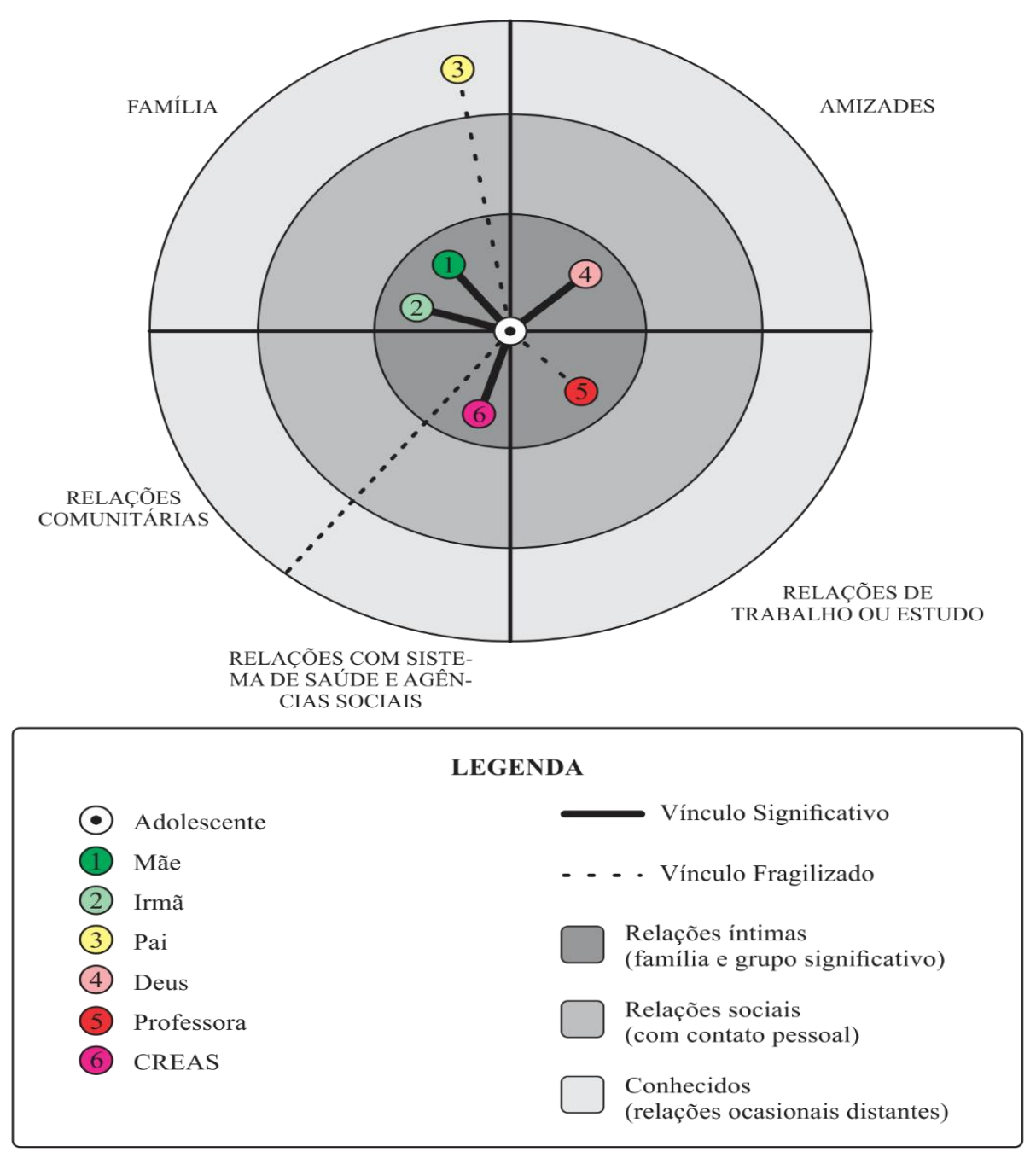

Figura 13 - Mapa de rede social do adolescente em LA - Festa, 17 anos

$\mathrm{Na}$ análise deste grupo temático, pôde-se observar que, para os adolescentes em LA participantes do estudo, existem alguns componentes das redes sociais os quais atuam de maneira mais significativa como fatores protetores em relação ao ato infracional. São eles: o vínculo com o CREAS e sua equipe, a escola, a igreja e projetos sociais, como o PROMAM.

\subsubsection{Membros da rede social: destaque para figuras femininas}

Nos dados, encontrou-se forte presença de figuras femininas no discurso de todos os 26 adolescentes, em especial a figura materna, referenciada por 25 deles. A adolescente que não referenciou a mãe havia sido abandonada pela mesma ao nascer. Além disso, observou-se também a presença de figuras como madrasta, madrinha, avó, tia, irmã, amiga e namorada. Os mapas dos adolescentes Prestativo e Tean Sagon são exemplos desse relato. 


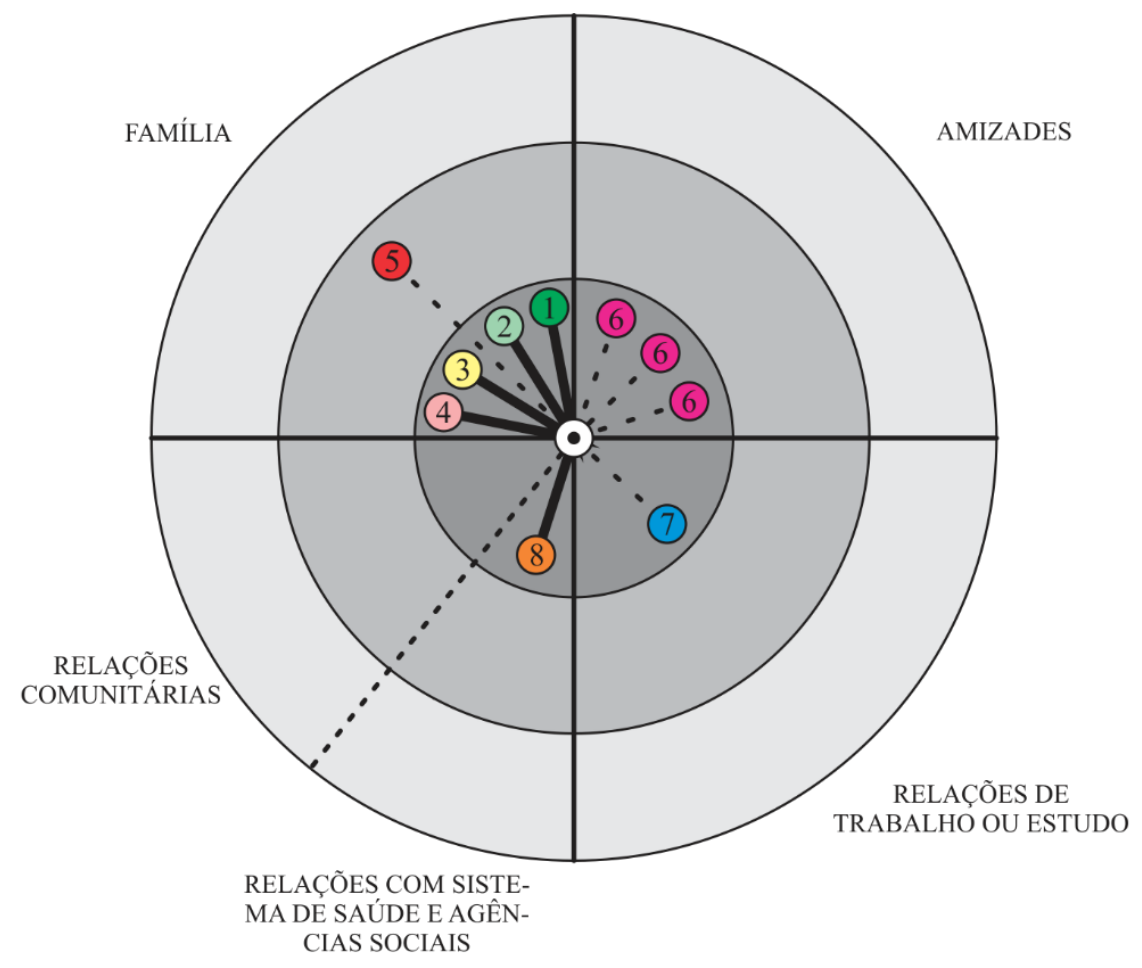

LEGENDA
- Adolescente
Vínculo Significativo
(1) Mãe
(2) Avó
(3) Tia
- - Vínculo Fragilizado
(4) Namorado(a)
(5) Padrasto
(6) Amigo(a)
(7) Colega de escola
(8) CREAS
Relações íntimas
(família e grupo significativo)
Relações sociais
(com contato pessoal)
Conhecidos
(relações ocasionais distantes)

Figura 25 - Mapa de rede social do adolescente em LA - Tean Sagon,17 anos 


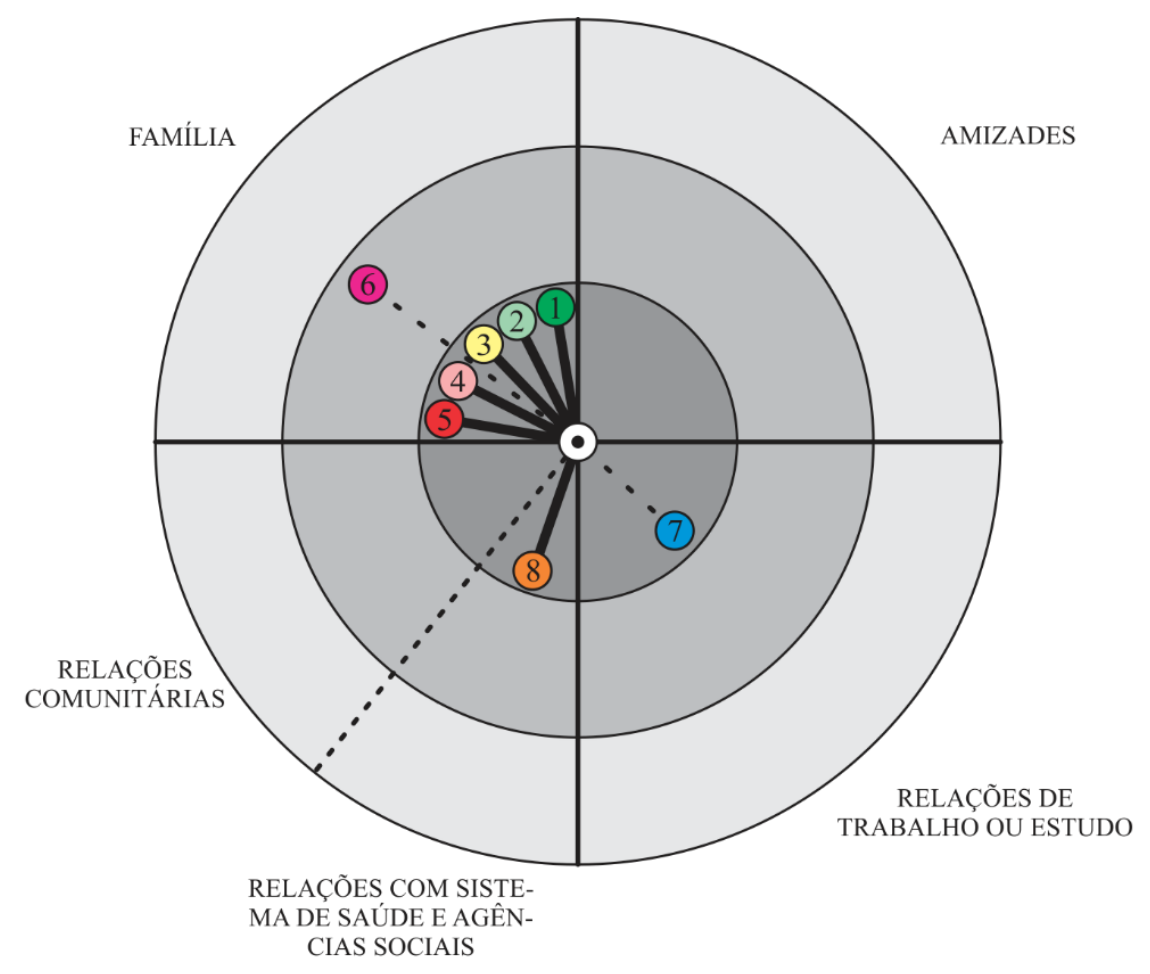

\section{LEGENDA}

- Adolescente

(1) Mãe

(2) Pai

(3) Avó

(4) Irmã

(5) Madrinha

(6) Tio

(7) Professora

(8) Psicólogo - CREAS

\section{Vínculo Significativo}

- - Vínculo Fragilizado

Relações íntimas (família e grupo significativo)

Relações sociais (com contato pessoal)

\section{Conhecidos}

(relações ocasionais distantes)

Figura 23 - Mapa de rede social do adolescente em LA - Prestativo, 15 anos

Ademais, ao serem indagados pela pesquisadora em relação a quem os ajuda a enfrentar as dificuldades e os problemas do dia a dia, encontram-se as seguintes respostas:

(...) quem me ajuda muito mesmo é minha mãe e minha avó. Elas me ajudam. Se eu faço algo errado, elas dizem que eu não devo fazer isso, pois é ruim. (Dança)

Recebo apoio da minha madrasta, principalmente no dia de natal, quando eu fico triste por causa da falta da minha mãe. Ela conversa comigo e me orienta em várias coisas, me dá carinho, dá atenção, dana, faz todo tipo de ajuda. (Branquinha)

A minha namorada me ajuda, principalmente quando eu brigo com meus pais ou acontece alguma coisa lá em casa. Ela puxa minha orelha, me dá conselhos, esfria minha cabeça. (Lutador) 
Nas redes sociais, essas figuras desempenham papeis de suporte, tanto na condução do cumprimento da medida de LA quanto no oferecimento de apoio emocional, conselhos, regulação e controle social e ajuda material (financeira) e serviços. Os excertos a seguir corroboram essa análise:

Minha mãe me dá conselho para eu ser boa pessoa, não usar droga, não mexer com ninguém, não brigar. É muito bom isso, me ajuda. (Lagoa)

Minha mãe me dá exemplos bons e fala para não fazer coisas erradas e manda eu procurar um emprego, fazer alguma coisa na vida. (Igreja)

Recebo ajuda da minha mãe, minha madrinha e minha avó. Elas me dão dinheiro para comprar roupa, sapato, material da escola... Esses trens assim. (Prestativo)

Minha mãe manda eu vir aqui ( CREAS) e fala que eu tenho que cumprir o que devo. (Moreninha)

Minha mãe e minha vó ficam falando todo dia, me perguntando e lembrando, "você já foi lá (CREAS), hoje?" "Você vai??" Não tenho como eu esquecer. (Piercing)

Quando os adolescentes foram convidados a identificar se faltava algum tipo de apoio em suas vidas ou se gostariam de receber algum tipo especial de apoio, eles relataram ausências relacionadas às figuras maternas que, em algum momento, por algum motivo, não estiveram presentes ou não ofereceram os cuidados que eles necessitavam. É interessante observar que apesar da figura da mãe constituir a rede dos adolescentes, eles relatam sentir sua ausência em determinados momentos:

(...) se ela (mãe) tivesse me dado mais atenção, tivesse falado mais sobre o que é a vida, eu não teria feito, eu não teria ido pela voz do mundo, ter escutado os outros. (Moreninha)

Minha mãe não me ajuda muito não... Ninguém me dá carinho. Ela só me sustenta. Vivo sozinho. (Vergonhoso)

A única adolescente que não mencionou a presença da mãe, assim relatou:

Eu queria mais apoio da minha mãe, queria receber carinho, atenção, dizer eu te amo. (Branquinha)

A estrutura familiar dos adolescentes é um elemento indispensável para a compreensão das redes sociais e seu papel de apoio. Nesse sentido, de fato, na sociedade brasileira, a mulher ocupa uma centralidade relacionada aos cuidados da vida doméstica, dos filhos e dos companheiros, sendo muito responsável pela transmissão do afeto e da sensação de segurança. Esse aspecto reforça também a ideia de que, em algumas comunidades, ainda é forte o papel social da mulher como mãe e esposa, por exemplo. 
A forte referência à importância das figuras femininas também reflete uma valorização pela vivência no contexto de família por parte dos adolescentes. Para eles, a vida na família acaba sendo ou a porta de entrada para as experiências negativas, como aquelas que os levaram a cometer um ato infracional, ou para experiências que são positivas e possuem caráter mais protetivo em relação aos demais contextos que eles estão inseridos e que, muitas vezes, é de vulnerabilidade e risco. Isso pode ser medido quando há uma percepção de carinho ou de afeto nesta dimensão da vida.

Se os adolescentes fazem arte e por que não tem carinho dentro de casa. E se não tem em casa a gente procura na rua e ai pode encontrar pessoas que não são boas. (Moreninha)

Minha família me ajuda... Minha mãe me incentiva. Quando acordo cedo e tô com preguiça de ir para escola, ela diz "você tem que pensar no futuro. Se você parar, vai atrasar sua vida". Meu pai diz que eu tenho que ter calma para não brigar na escola, se não vai petecar tudo, vai atrasar meu currículo. Minha irmã diz sempre que devo vencer os obstáculos e passar por cima deles e seguir para frente. (Moda)

Especificamente no que se refere à força das figuras femininas nos discursos e nos mapas de rede dos adolescentes, as pesquisas consideram haver um forte fator de influência do gênero na maneira como as redes sociais se organizam em sua composição. Um estudo mais antigo de Fischer (1982), por exemplo, verificou, nos anos 1980, que pessoas do sexo feminino tende a se envolver mais com parentes e pessoas das famílias, ao mesmo tempo em que descrevem relações mais próximas que pessoas do sexo masculino.

É claro que esta questão de gênero é um fator também marcante da nossa sociedade e de como temos nos organizado nas últimas décadas no que se refere ao cuidado dos filhos e da família e da inserção da mulher no mundo do trabalho. Todavia, atualmente, as famílias têm se mostrado diferente na maneira como se organizam, se estruturam e se relacionam, o que coloca em xeque o estabelecimento dos papeis e das funções no conjunto familiar, bem como no tipo de apoio que cada um vai oferecer na composição das redes de seus membros.

Ainda nessa perspectiva, Alexandre et al. (2012) observa que o gênero feminino contribui de forma significativa no processo de desenvolvimento do ser humano. A figura feminina exerce papel de influencia cultural e hierárquica, em que o cuidado às crianças é atribuído à mãe e à sua rede de sociabilidade, por meio da confiança depositada em outras mulheres, como avó, tia, irmã e madrasta.

Neste estudo, o fato de as mães e outras mulheres estarem mais presentes na oferta de apoio aos adolescentes em LA também pode ser entendida como reflexo das 
questões sociais de gênero e de como o papel do cuidado e do apoio ainda é na nossa sociedade muito relacionada a pessoas do sexo feminino. Muitas vezes isso foi medido também pela ausência do pai ou de uma figura masculina que auxiliasse as diferentes mulheres nas tarefas da casa ou mesmo no cuidado dos filhos.

Um estudo realizado por Branco e Wagner (2009) com foco na compreensão do sucesso ou não do cumprimento de medida socioeducativa à luz das características da rede social identificou, por meio de mapas de rede social, a importância da família, sendo a figura da mãe a fonte central de apoio e vínculo significativo. Nesse estudo, também apareceu à namorada como uma figura relevante na rede.

Por sua vez, Dib; Bazon; Silva (2012); Bazon et al.(2011) identificaram que existem divergências na produção científica sobre como a falta de apoio do pai e da mãe pode ser determinante para o envolvimento dos adolescentes em atos infracionais. Esses autores bem como Nunes, Andrade e Morais (2013) constataram que quanto menor o apoio familiar, especialmente da mãe e do pai, maior é a possibilidade de envolvimento com o ato infracional.

Nessa mesma perspectiva, estudos realizados por Nardi (2010) e Nardi; Dell'Aglio (2012) revelaram que os adolescentes em conflito com a lei lembram, primeiramente, da figura da mãe e, a seguir, da figura do pai ou figuras familiares secundárias, como também ocorreu com os adolescentes participantes deste estudo. Sluzki (2006; 2010) pontua que a família é, enfim, vista como primeiro espaço educativo e de socialização das pessoas e para a construção de identidades, costumes e tradições.

No mapa de rede dos adolescentes do estudo, percebeu-se, também, a presença de laços de amizade, predominando figuras do sexo feminino. Nas falas dos adolescentes essas amizades aparecem com sentimentos de desconfiança devido a alertas que receberam, sobretudo da família. Segundo os adolescentes, em geral, as amizades são negativas e deve-se ter muito cuidado ao se envolver com as pessoas que não são dignas de confiança. Entretanto, alguns mencionam que os amigos são fonte de apoio positivo, principalmente no que se refere às conversas.

Vale destacar que 16 adolescentes referenciaram a presença de amigos, especialmente amigas, em sua rede e que estes foram os únicos membros descritos com a função de companhia social. Segundo os adolescentes, os (as) amigos (as):

Conversam comigo. Eu estou errado, mas eles ficam falando comigo, tenho escutado. É legal, bom, me sinto importante recebendo ajuda. (Amizade) 
Eu recebo ajuda dos amigos. Quando fico triste converso com eles. Eles servem para sair comigo também, né. (Companheiro)

O adolescente Lutador foi o que mais apresentou os amigos em seu desenho do mapa de rede, mesmo com vínculos frágeis, como se pode observar a seguir.

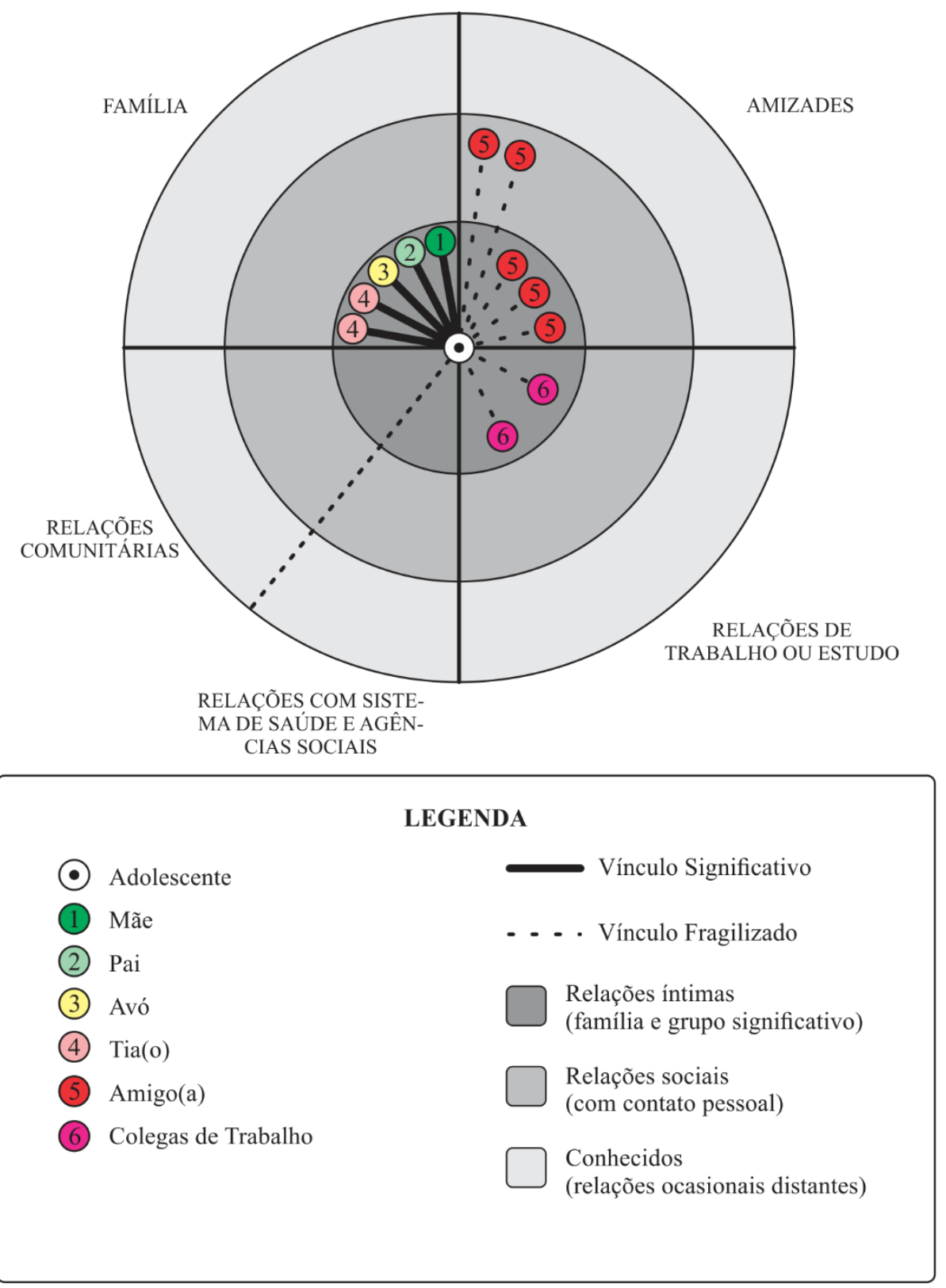

Figura 17 - Mapa de rede social do adolescente em LA - Lutador, 18 anos

Destaca-se ainda a referência feita pelos adolescentes sobre a influência dos amigos (as) ou colegas para o início ou a prática do ato infracional. Percebe-se que há ressentimento com essas pessoas, pois aparecem com vínculos frágeis, associados como parceiros apenas para coisas erradas ou que fogem às regras sociais (como os atos infracionais). Também há referência para o fato de alguns desses amigos terem sumido no 
momento de dificuldade, o que também foi encontrado em outros estudos (BRANCO; WAGNER, 2009).

No que se refere a essas relações sociais, a figura de namorados (as) também aparecem como fonte de apoio significativa para os adolescentes:

Eu comecei a namorar esses dias, então estou recebendo muito carinho, atenção, (Cantora)

Recebo ajuda da namorada. Ela conversa comigo e me explica as coisas, como é e como não é. Explica o que é certo e o que é errado. (Amizade)

A seguir, enfoca-se a rede social enquanto essencialidade na vida dos adolescentes em LA.

\subsubsection{A essencialidade da rede social}

Conforme se pode depreender das análises realizadas até aqui, a rede social representa papel essencial na vida dos adolescentes participantes deste estudo, pois, sem ela, eles poderiam se envolver em situações de maior vulnerabilidade ou contravenção, além de não conseguirem levar adiante suas vidas, já que uma de suas principais razões de ser referese exatamente ao apoio que recebem. Os excertos a seguir são representativos desta análise:

A ajuda é essencial, porque sem ajuda ninguém dá conta de viver. (Companheiro)

A ajuda é importante, pois me faz bem e feliz. (...) Sem eles (o apoio dos pais) eu não teria amor e atenção. (Branquinha)

O apoio relativo às orientações e ao aconselhamento, principalmente pela família, com destaque para a figura da mãe, foi aquele que mostrou mais essencialidade na vida dos adolescentes participantes do estudo. A figura da mãe, em especial, se mostrou como aquela responsável por apontar os caminhos certos e errados, orientar em casos de problemas com vida e ouvir o que os adolescentes têm a dizer.

Meu pai, ele ajuda em tudo, como se fosse um amigo; posso contar com ele em tudo, em qualquer dificuldade... Pode ser o que for, ele tá ali sempre, vem conversar comigo, ver o que está acontecendo... Se tiver alguma coisa ruim, tem como eu falar com ele, aí eu falo. Minha mãe ajuda da mesma forma, só que com a minha mãe eu tenho maior intimidade. Com meu pai são as coisas do mundão; agora a minha mãe é mais para as coisas que acontecem assim comigo, coisas assim... Minha mãe é mais carinhosa, meu pai também... Meu pai ajuda financeiramente, chama atenção quando precisa. (Violão)

Recebo conselho da minha mãe, do meu pai, meus tios, dos amigos que também dão muitos conselhos. (...) Os conselhos é que ajudam mesmo... Você vai juntando 
coisas boas, ai mais pra frente, se você for estudar, você se lembra das coisas... (Motorista)

A família, portanto, aparece como o grande centro do apoio, mas às mulheres couberam questões mais do afeto e do cuidado, ao passo que aos homens, principalmente os pais, couberam principalmente o apoio em termos materiais. Todavia, observou-se que numa sociedade na qual a dinâmica familiar vem se transformando, a figura feminina, neste caso a mãe, principalmente, também surge como provedora de recursos materiais, conforme pode-se observar nas falas a seguir:

Minha mãe me ajuda muito, questão financeira, apoio também, minha tia também me dá muito conselho, também me ajuda financeiramente se eu precisar dela. (Igreja)

Da minha mãe eu recebo tudo. Ela me dá alimentação, roupa e material de escola, estas coisas que a gente precisa para viver. (Capoeira)

Recebo da minha mãe várias coisas. Me dá roupa, calçado, um lugar para eu morar. (Aventura)

Os profissionais do CREAS também se mostraram essenciais na vida dos adolescentes em LA participantes deste estudo. Além de oferecer apoio emocional e material, aconselhamento e controle, esses profissionais também se mostraram essenciais no sentido de possibilitar acesso a novos contatos e ampliar sua rede social:

Nem tanto bens materiais, igual quando eu vir pra cá eu era uma menina rebelde, hoje me sinto melhor na sociedade, porque eu estou abrindo as portas pra min ver melhor, hoje eu tenho liberdade de expressão, posso falar o que quiser que ninguém vai me repreender, eu não tinha isso antes e isso eu construí com a ajuda do CREAS. (Moda)

(...) se tiver passando dificuldade ela (a assistente social) me ajuda também, se eu precisar dela a qualquer hora ela me ajuda. Nesse sentido assim. (Igreja)

Entrevistadora: O que poderia ajudar os adolescentes a não se envolverem com atos infracionais?

Futebol: (...) ter um acompanhamento com psicólogo e assistente social (...) eles ajudariam a não entrar nesse mundo do crime, esquisito, e não cometer esses atos.

Aqui no CREAS posso participar do teatro uma vez por semana. É bom. Faço até novas amizades. (Moreninha)

Eu posso até fazer aula de violão. E aproveito bastante para conversar com meu professor de violão. Às vezes ele arruma uns lugares para min cantar. (Cantora)

A relação com a família, principalmente os pais e as mães, bem como o CREAS, têm papel essencial na vida dos adolescentes. Na avaliação das falas dos adolescentes participantes deste estudo, essas relações têm influência no que se refere ao envolvimento 
com o ato infracional. Em geral, a percepção dos adolescentes é de que se há um ambiente de carinho, afeto e segurança, não haverá envolvimento com "coisas" ou "pessoas erradas". Nesse sentido, Dong; Krohn (2015) pontuam que o apoio dos pais funciona como fator protetivo, podendo assegurar o afastamento do adolescente de atos infracionais. Nota-se, portanto, que o apoio recebido por esses adolescentes é composto não apenas por aspectos subjetivos, mas também por apoio material e informativo.

Ainda nesse tocante, Castells (1999) afirma que, os vínculos sociais colocados em posições estratégicas facilitam as oportunidades, auxiliando de maneira considerável na aquisição de possibilidades de acesso aos recursos disponíveis através das redes, daí a essencialidade do CREAS na vida desses adolescentes em LA. Para esses adolescentes, uma rede bem delineada mostra importante contribuição para a mudança de projetos de vida e mesmo o suporte necessário para deixarem a situação de vulnerabilidade desencadeadora do ato infracional.

As análises realizadas neste trabalho corroboram a observação de Costa e Assis (2006), quando as autoras pontuam que o estímulo para o adolescente formar vínculos significativos com outras pessoas e instituições, ampliando a rede social, favorece seu desejo rumo à construção de um projeto de vida que vislumbre um futuro feliz diferente do associado ao ato infracional. Esse é o sentido que se depreende das falas e dos desenhos dos adolescentes em LA aqui pesquisados. A rede social, portanto, se mostrou essencial para esses adolescentes no sentido de propiciar a eles uma nova visão de mundo que ultrapassa o nível da criminalidade, oferecendo-lhes reais possibilidades de mudança por meio da educação, da profissionalização e da esperança de um novo projeto de vida e, consequentemente, a um futuro melhor.

\subsubsection{Processo de adolescer e o cumprimento da LA}

A adolescência é um momento do crescimento e desenvolvimento humano, marcada por passagens e transformações específicas de nível fisiológico e psicológico. Nesse momento do desenvolvimento, há uma construção da identidade em um movimento de contradições e assimilações (FERNANDES; FERREIRA; CABRAL, 2011). Para esses autores "a peculiaridade desta fase favorece agravos de sua saúde física, emocional e social, principalmente devido ao uso de drogas lícitas e ilícitas, a violência, distúrbios de sexualidade, doenças sexualmente transmissíveis e gestação na adolescência” (p. 1). 
Ao analisar as falas dos adolescentes participantes do estudo, identificaram-se alguns elementos que remetem ao processo de adolescer. Eles destacam que a adolescência é uma fase pela qual todo mundo passa e que nela há momentos de preguiça. Segundo eles, nesse período é necessário que eles desenvolvam um senso de juízo para cuidar da vida, conforme ilustra a fala a seguir:

(...) a fase que eu cometi esse delito é uma fase que todo jovem passa, mas só que tem dois caminhos a seguir, tentar uma vida melhor, ou tentar ser popular e envolver com coisa errada. Isso é um caminho óbvio, não tem como você desviar e, infelizmente, os jovens tão seguindo o caminho errado, que é o caminho de glamour, de tudo, de sair, ter amigos, tudo... Seguem o caminho errado, aí não tem jeito. (Moda)

Os adolescentes justificam o ato infracional como natural e algo relacionado ao momento do desenvolvimento em que se encontram. Nesse sentido, Espíndula e Santos (2004) sugerem duas representações sociais de adolescência: a "normal”, caracterizada por um momento de transição, onipotência e dificuldades no processo de desenvolvimento; e a infratora, "diferente", oriunda de uma "família desestruturada", representação que serve de modelo para as interações conflituosas que levam à infração.

Os adolescentes do estudo destacam a necessidade de apoio por parte de algumas pessoas para conduzir o seu processo de adolescer. Esse apoio pode ser de diferentes formas e, em geral, está relacionado aos pais e à família.

Entrevistadora: O que poderia ajudar os adolescentes a não se envolverem com atos infracionais?

Tímido: Ter mais orientação do pai e da mãe... Conversar mais, explicar... E a gente também tem que escutar mais. É que às vezes a mãe da gente fala: não anda com ele não e você nem dá bola. Aí você não pensa. Depois é que você vai pensar e ai já é tarde demais. Mas também não adianta conversar se o adolescente não escuta. Ah, tem que falar pra eles tirarem um tempo pra conversar com a mãe, o pai algum dia. Receber mais atenção. Eu acho que se tivesse tido mais atenção, eu não estaria com pessoa errada, mas eu também não dava atenção... A culpa foi minha também. É mais do adolescente. Hoje eu vejo diferente.

As relações com os pais aparecem como fatores protetivos para o não envolvimento em situações de criminalidade.

O pai e mãe têm que estar do lado da gente, assim a gente não se envolve com esse lado (do crime). (Namorador)

Meu pai e minha mãe me ajudam; eles me ouvem. E me manda ir para escola e dizem para não ficar na rua e nem envolver com qualquer amizade. (Dança) 
As dimensões de desenvolvimento apresentadas pelos adolescentes acabaram retomando o tema das figuras da família e como elas são importantes para a compreensão do processo de adolescer, mesmo quando analisamos seu envolvimento com situações de ato infracional ou conflito com a lei. Isso pode ser constatado nas falas citadas acima e graficamente nos dois mapas a seguir, em que essas figuras da família estão presentes com vínculos significativos.
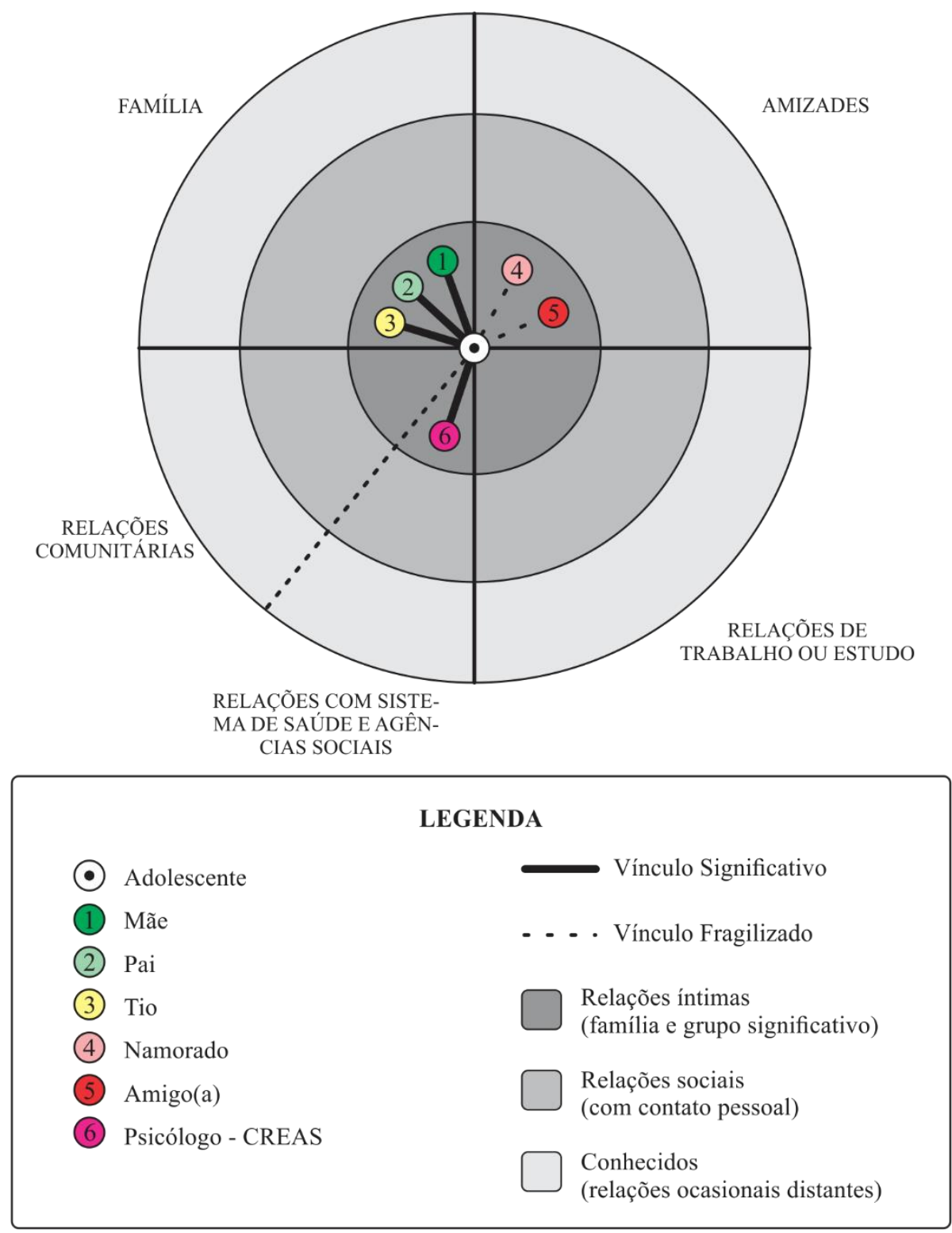

Figura 9 - Mapa de rede social do adolescente em LA - Companheiro, 17 anos 


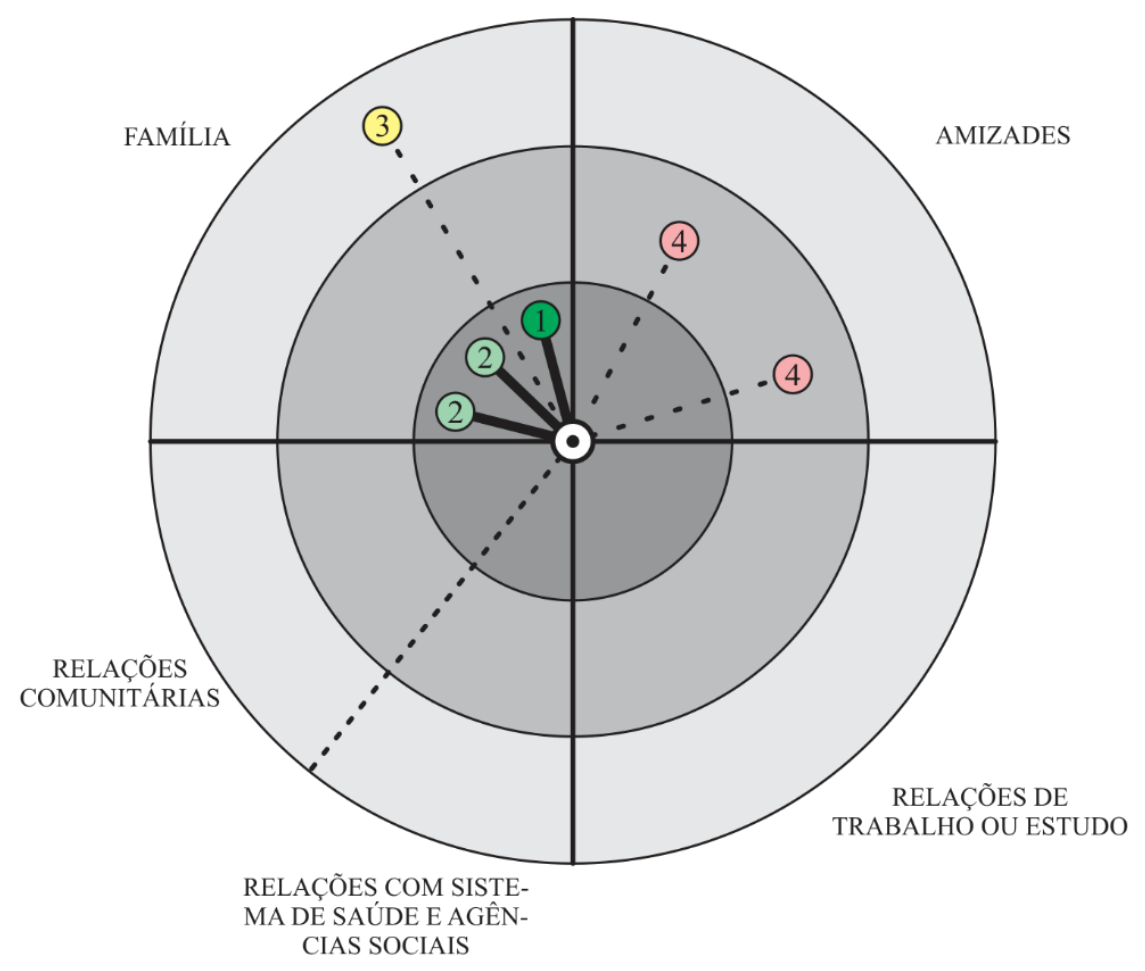

LEGENDA

- Adolescente

(1) Mãe

(2) Irmãs

(3) Pai

(4) Amigo(a)

Vínculo Significativo

. - Vínculo Fragilizado

Figura 4 - Mapa de rede social do adolescente em LA - Aventura, 15 anos

Pensar o processo de adolescer sob a perspectiva das redes sociais é concebê-la na sua mais ampla interdependência com outras dimensões da vida em sociedade. A rede social, ilustrada neste trabalho pelos desenhos dos adolescentes, é uma boa referência para se compreender processos de desenvolvimento e como os diferentes atores, setores e componentes da rede podem significar, por exemplo, saúde, adoecimento, convívio e interações sociais positivas ou conflituosas.

Sluzki (2006) defende que é na lógica das redes que se pode pensar como as relações de ajuda e de apoio potencializam a vida em sociedade e fortalecem pessoas, grupos e comunidades, o que, neste trabalho, é representativo para os adolescentes em LA. Uma das maneiras pelas quais podem ser compreendidas as influências positivas da rede social no processo de adolescer, por exemplo, é o seu caráter de estímulo à convivência entre pessoas 
que favorecem comportamentos saudáveis e voltados para o desenvolvimento social e comunitário das pessoas e dos grupos.

Neste sentido, percebeu-se que tanto a família como a equipe do CREAS ofereceram mecanismos de auxílio no processo de adolescer. Esses mecanismos envolveram, por exemplo, apoio emocional, carinho, escuta ativa, aconselhamento, regulação da conduta.

Em face do exposto, percebe-se que as atividades socioeducativas são importantes ferramentas para a vida adolescente em conflito com a lei e se colocam como essenciais em suas redes sociais na medida em que extrapola as limitações impostas pelas medidas de privação de liberdade. No caso da LA, as atividades socioeducativas favorecem o convívio social e a manutenção dos vínculos com pessoas significativas, o que para a adolescência é muito importante. Ao mesmo tempo, possibilitam ao adolescente reorientar o curso e a história de sua vida. Monteiro et al. (2011) destaca que os adolescentes em conflito com a lei são vítimas da violência social, decorrente de um processo de exclusão de medidas e condições necessárias à promoção do processo adolescer.

Apresenta-se, a seguir, a conclusão e as considerações finais do estudo. 


\section{CONCLUSÃO}

Esta tese se propôs a investigar a rede social de adolescentes do município de Patos de Minas, interior de Minas Gerais, os quais se envolveram em atos infracionais e estavam cumprindo a medida socioeducativa no âmbito da liberdade assistida e da proteção social. Nesse sentido, partiu-se do pressuposto de que esses adolescentes possuem capacidade de perceber e elencar as características de sua rede social.

Argumentou-se, neste estudo, que uma rede social, com vínculos fortes, tem impacto no que diz respeito à conduta infracional dos adolescentes em LA. Tal rede, quando saudável, pode afastar ou impedir os adolescentes do engajamento com o ato infracional. Isso posto, estabeleceram-se os seguintes objetivos de pesquisa:

- Analisar os sentidos da rede social dos adolescentes em LA no município de Patos de Minas, estado de Minas Gerais.

- Conhecer o perfil socioeconômico e demográfico desses adolescentes.

- Analisar as características das dimensões estruturais, das funções e dos atributos dos vínculos presentes nas redes sociais desses adolescentes.

Para responder a esses objetivos, realizou-se um estudo exploratório, descritivo, de abordagem qualitativa. $\mathrm{O}$ estudo teve a participação de 26 adolescentes com idades de 13 a 18 anos, os quais estavam em cumprimento da medida socioeducativa LA no Centro de Referência Especializado de Assistência Social - CREAS, no município de Patos de Minas, durante os meses de janeiro a março de 2014, momento em que os dados foram coletados.

Para a coleta dos dados, utilizou-se de uma entrevista semiestruturada e da construção de mapas de rede social, conforme propõe Sluzki (2010). Os dados foram analisados de acordo com os pressupostos do método de interpretação de sentido, conforme Gomes (2009).

À guisa de conclusão sintetizam-se, a seguir, os resultados das análises dos dados para, depois, apresentarem-se as considerações finais.

\subsection{O PERFIL SOCIOECONÔMICO E DEMOGRÁFICO DOS ADOLESCENTES DO ESTUDO}


Dezenove, dos vinte seis adolescentes participantes deste estudo eram do sexo masculino. Cinco deles tinham 18 anos, sete tinham 17 anos, um tinha 16 anos, cinco tinham 15 anos, quatro tinham 14 anos e um tinha13 anos. Dezenove haviam vivenciado experiências de reprovação escolar, dezesseis pertenciam a igrejas evangélicas e vinte deles residiam casas alugadas.

Em relação ao tipo de ato infracional cometido, que justificava a presença do adolescente na medida LA, o roubo obteve a maior ocorrência (10 adolescentes), seguido por brigas (cinco adolescentes), envolvimento com tráfico de drogas (quatro adolescentes), direção sem carteira de motorista (três adolescentes), porte de arma branca (dois adolescentes), crime contra o patrimônio (um adolescente) e uso de identidade falsa (um adolescente). A renda mensal familiar predominante variou entre um a dois salários mínimos (18 adolescentes).

Esse perfil reflete na estruturação e configuração de suas redes sociais, conforme mostra o próximo item.

\subsection{DIMENSÕES ESTRUTURAIS, FUNÇÕES E ATRIBUTOS DOS VÍNCULOS NAS REDES SOCIAIS DOS ADOLESCENTES DO ESTUDO}

A representação gráfica dos mapas de rede social dos 26 adolescentes em LA participantes deste estudo possibilitou a análise das características estruturais de sua rede social no quesito tamanho, densidade, composição, dispersão e aspecto de homogeneidade e/ou heterogeneidade. Observou-se que 17 adolescentes apresentaram uma rede social de tamanho significativamente pequeno, composta por uma a sete pessoas. Na composição dessa rede, observou-se a presença da família, do CREAS e dos amigos, ao passo que a escola e o trabalho tiveram pouca representatividade.

Constatou-se, também, uma lacuna ou ausência de representantes da comunidade e dos serviços de saúde em sua rede social. Apontou-se, neste estudo, a gravidade da ausência de membros da comunidade e dos serviços de saúde na rede social, ou seja, evidenciou-se, nos mapas, a inexistência de vínculo entre os adolescentes e os recursos sociais (vizinhos, por exemplo), bem como entre os adolescentes e os profissionais de saúde, tais como aqueles que se dedicam à atenção básica a saúde.

$\mathrm{Na}$ análise da densidade, nas relações de intimidades/proximidade, destacaramse a presença da figura da mãe, citada por 23 adolescentes, seguida pelos amigos (13 adolescentes), irmãos (10 adolescentes), a instituição CREAS (11 adolescentes), os 
psicólogos do CREAS (10 adolescentes), o pai (nove adolescentes) e avós e colegas de escola (sete adolescentes). Com menor representatividade destacaram-se namorado(a) (6 adolescentes), tio(a) (cinco adolescentes), professor(a) (quadro adolescentes), patrão (três adolescentes), colega de trabalho (dois adolescentes), prima (um adolescente), padrasto (um adolescente), assistente social (um adolescente), professor de violão do CREAS (um adolescente), madrasta (um adolescente), Deus (um adolescente), madrinha (um adolescente).

No âmbito das relações sociais, espera-se encontrar pessoas ou instituições que possuam menos contato e menor nível de compromisso com os adolescentes. Todavia, cinco adolescentes referenciaram o pai e dois adolescentes referenciaram a mãe nesse círculo relacional. Quatro pais também apareceram nas relações com conhecidos, além de outros familiares, professor.

Em relação aos vínculos significativos destacaram-se a mãe (22 adolescentes) seguida do psicólogo do CREAS e irmãos (12 adolescentes), CREAS (11 adolescentes), pai (nove adolescentes), avó (sete adolescentes), tio(a) (cinco adolescentes), namorado(a) (três adolescentes), amigos (três adolescentes), professor de violão CREAS (um adolescente), professor da escola (um adolescente), assistente social (um adolescente), patrão (um adolescente), madrasta (um adolescente), Deus (um adolescente), prima (um adolescente), madrinha (um adolescente). Percebe-se que os amigos (16 adolescentes), apesar de serem bastante referenciados nas relações íntimas, apresentaram-se com vínculos fragilizados para 13 adolescentes.

Nos vínculos fragilizados destacaram-se os amigos (13 adolescentes), pai (sete adolescentes), colega de escola (sete adolescentes), tio(a) (seis adolescentes), irmãos (quatro adolescentes), namorado(a) (quatro adolescentes), professor(a) (quatro adolescentes), primos (três adolescentes), mãe (dois adolescentes), patrão (dois adolescentes), colega de trabalho (dois adolescentes) e padrasto (um adolescente).

Nas relações com vínculo rompido, três adolescentes verbalizaram rompimento de vínculo com seus pais. Além disso, na análise da composição da rede social, percebeu-se a figura do pai ausente na composição de oito mapas referenciaram vínculo inexistente com o mesmo. Isso é relevante, pois mostra a distância afetiva com membros que poderiam apoiá-los em sua vida diária.

Em relação à dispersão, ou seja, a frequência de contato dos membros da rede com os adolescentes observou-se acesso semanal aos serviços do CREAS e contato diário com os membros das relações íntimas. A maioria dos adolescentes relatou dificuldade em 
chegar ao CREAS, devido à distância geográfica, pois a instituição está localizada no centro do município de Patos de Minas, enquanto a maioria dos adolescentes reside na periferia. Porém, verificou-se, nas falas dos adolescentes, que o acesso ao CREAS é facilitado pela ajuda financeira da instituição em forma de vale transporte.

$\mathrm{Na}$ análise da homogeneidade e heterogeneidade demográfica e sóciocultural, ou seja, idade, sexo, cultura e nível socioeconômico dos membros da rede social dos adolescentes, observou-se certo padrão no que se refere ao perfil socioeconômico e cultural dos membros da rede. No quesito idade e sexo, predominaram adultos na faixa etária de 25 a 40 anos bem como crianças de até 12 anos. Houve predomínio de membros do sexo feminino, sobretudo na figura da mãe, irmãs, tias, avós, amigas e madrastas. Em relação ao nível educacional, a maioria dos membros da rede possuía apenas o ensino fundamental incompleto. Vale lembrar que renda mensal predominante de seu núcleo familiar variava de um a dois salários mínimos.

Em face dos resultados acima, destacou-se a necessidade de realizar entrevistas com cada membro da rede social dos adolescentes participantes do estudo, com o intuito de elencar mais informações sobre a dispersão, homogeneidade, heterogeneidade e mesmo a reciprocidade do tipo de vínculo, aspectos que não foram contemplados nos objetivos desse estudo.

Ao analisar as funções dos vínculos das redes dos adolescentes, notou-se que nas figuras familiares, a mãe sobressaiu-se como a que mais oferece apoio, aparecendo nas funções de ajuda material e de serviços, guia cognitivo e de conselhos, apoio emocional e regulação e controle social. O CREAS também apareceu como instituição que desenvolve todas essas funções além de possibilitar acessos a novos contatos. Já os amigos apareceram desempenhando as funções de companhia social e apoio emocional. Esses apoios foram lembrados, pelos adolescentes, como recursos importantes de suas redes, ajudando-lhes diretamente.

Esses resultados ajudaram a compreender os apoios que influenciam, de alguma forma, na percepção de afeto e qualidade de vida. A escola e o trabalho apareceram de forma menos expressiva, desempenhando as funções de guia cognitivo e de conselhos, regulação e controle social, ao passo que as relações de trabalho assumiram o papel de regulação e controle social de forma menos expressiva. Não apareceram membros da comunidade, tampouco profissionais dos serviços de saúde.

Evidenciou-se, nas análises realizadas, que existem benefícios potenciais quando o tipo de apoio recebido é o formal, vindo dos pais, de outros familiares ou namoradas, mas 
também é significativa a importância dos vínculos com outras pessoas que oferecem outros tipos de apoio, como os vínculos estabelecidos com o patrão ou o colega de trabalho. Investigações adicionais poderão explorar como algumas fontes e tipos de apoio nas redes sociais podem ser mais efetivos para os adolescentes em LA ou qual a importância de cada um desses tipos de apoio para a saúde, o desenvolvimento humano ou o envolvimento em atos infracionais. Assim, nota-se a importância de identificar porque alguns vínculos variam em termos de qualidade ou intensidade e acabam sendo mais protetivos ou de risco para a adolescência.

Em síntese, ao analisar os atributos dos vínculos da rede social dos adolescentes participantes do estudo, percebeu-se que suas redes sociais apresentam tamanho reduzido, com uma distribuição de membros de forma irregular, com uma maior concentração de vínculos significativos nas relações íntimas com familiares, em destaque a figura da mãe, do pai e dos irmãos, e com a agência social (CREAS), na figura do psicólogo.

Assim, pode-se afirmar que a relação íntima e positiva dos adolescentes em LA e os membros da família, do CREAS, da escola e do trabalho são fontes protetoras capaz de auxiliar os adolescentes em LA a romper com a prática de ato infracional.

Em relação às funções dos vínculos desempenhadas, notou-se uma dinamicidade e um multidimensionamento do papel dos membros da rede social. O CREAS se destacou no desempenho da função de propiciar acesso a novos contatos. Já os amigos foram lembrados como companhias sociais e apoio emocional, enquanto a família mostrou desenvolver várias funções, como apoio emocional, ajuda material, guia cognitivo e de conselhos, regulação e controle social. Por sua vez, os colegas de trabalho e membros da escola, professores e colegas foram citados como possível fonte de apoio na regulação e controle social. Em relação à frequência do contato, observou-se acesso semanal aos serviços do CREAS e contato diário com os membros das relações íntimas.

Como conclusão, este estudo retrata a importância da família, na figura da mãe e outras figuras femininas, nas redes sociais dos adolescentes em LA. Mostra, ainda, que a figura do pai ou de outros homens são mais distantes ou até mesmo ausente. Os profissionais do CREAS, especialmente os psicólogos, foi citado como importante elemento da rede social, oferencendo diferentes tipos de apoio, refletindo que programas governamentais têm sido essenciais na oferta de apoio a pessoas e grupos.

Nem todos os adolescentes incluíram os amigos em seus desenhos de rede e a experiência com alguns professores foi considerada positiva, mas ainda com aspectos negativos no que se refere a experiência com a escola em si. 


\subsection{SENTIDOS ATRIBUÍdOS PELOS ADOLESCENTES EM LA EM RELAÇÃO A SUA REDE SOCIAL}

Os dados analisados indicam a multiplicidade de sentidos que os adolescentes em LA atribuíram a sua rede social. Compreender tais sentidos é importante no sentido de orientar as práticas e ações desenvolvidas no âmbito da saúde coletiva, para o alcance de sua promoção social.

Em face do exposto, analisaram-se os conjuntos dos mapas dos adolescentes participantes do estudo, bem como suas falas nas entrevistas. Adotou-se um olhar contextual indo dos conteúdos do texto até o contexto em que esse texto foi produzido. Ou seja, buscaram-se as lógicas e as explicações dos adolescentes em LA, tendo em vista seu contexto de vida e sua cultura. A partir daí, identificaram-se quatro núcleos de sentido em suas redes sociais, quais sejam: 1) serviços e engajamento social; 2) membros da rede social: destaque para figuras femininas; 3) essencialidade da rede social e 4) processo de adolescer e o cumprimento da LA.

Nesse sentido, a análise evidenciou a importância de serviços e engajamento social. O CREAS se destacou no sentido de auxiliar o adolescente a perceber novas possibilidades de vida, enquanto os serviços de saúde, bem como a escola e a própria comunidade, apareceram ausentes. A identificação das lacunas ou mesmo das fragilidades das instituições de saúde e de educação permitiu uma melhor compreensão de seu potencial com relação a saúde e a inserção social dos adolescentes. Nesse escopo, a articulação dos serviços e da equipe de saúde, bem como dos profissionais da educação, torna-se essencial para transformar o quadro de vulnerabilidade, com vistas a efetivação dos direitos dos adolescentes no contexto do cumprimento da medida socioeducativa LA.

Observou-se que a rede social é capaz de propiciar um engajamento social, por meio de seus membros, com destaque da figura da mãe e o dos profissionais do CREAS, no sentido de serem essenciais para o acompanhamento do próprio processo de adolescer e o cumprimento da LA, além de auxiliarem o adolescente a evitar a recidiva infracional e a trilhar uma nova trajetória de vida sem envolvimento com atos infracionais.

Outro sentido observado na rede social dos adolescentes foi em relação aos membros da rede social com destaque para figuras femininas. Perceberam-se relatos fortes sobre a importância dessas figuras no contexto do apoio emocional, ajuda material, guia de conselhos e regulação social, além do auxílio no cumprimento da medida LA. 
Também foi elencado o sentido do papel da família e do CREAS para o restabelecimento de um renovado convívio social, possibilitando novos projetos de vida desvinculados de práticas delituosas, como propõe a medida socioeducativa LA. Neste estudo, os adolescentes apontaram as ações desenvolvidas dentro da LA e como elas os ajudaram a superar o momento de dificuldade vivido com o ato infracional.

Outro sentido encontrado refere-se à essencialidade da rede social na vida destes adolescentes. Para eles, a rede social representa papel essencial em suas vidas, pois, sem ela, eles poderiam se envolver em situações de maior vulnerabilidade ou contravenção, além de não conseguirem levar adiante suas vidas, já que uma de suas principais razões de ser referese exatamente ao apoio que recebem. A rede social, portanto, se mostrou essencial no sentido de propiciar a eles uma nova visão de mundo, a qual ultrapassa o nível da criminalidade, oferecendo-lhes reais possibilidades de mudança por meio da educação, da profissionalização e da esperança de um novo projeto de vida e, consequentemente, a um futuro melhor.

Nessa perspectiva, constatou-se que a medida socioeducativa LA ultrapassa sua dimensão política e institucional. Percebeu-se que as atividades socioeducativas são importantes ferramentas para a vida do adolescente em conflito com a lei e se colocam como essenciais em suas redes sociais na medida em que extrapola as limitações impostas pelas medidas de privação de liberdade. No caso da LA, as atividades socioeducativas favorecem o convívio social e a manutenção dos vínculos com pessoas significativas, inclusive com os profissionais que executam essa medida, já que compõem as redes sociais dos adolescentes de forma afetiva e significativa. Tudo isso permite ao adolescente reorientar o curso e a história de sua vida.

Enfim, a medida socioeducativa LA mostrou-se como uma estratégia política assertiva no que se refere a redução de danos associados aos atos infracionais. Foi fundamental no sentido de promover, de maneira saudável e responsável, o convívio social desses adolescentes, o que certamente irá levá-los a evitar a reincidência de atos infracionais.

O sentido da rede, no que diz respeito ao processo de adolescer e o cumprimento da LA revelou sua interdependência com outras dimensões da vida em sociedade. A rede social, ilustrada neste trabalho, pelos desenhos dos adolescentes, mostrouse uma boa referência para se compreender o processo de desenvolvimento do adolescente e como os diferentes atores, setores e componentes da rede podem significar, por exemplo, saúde, adoecimento, convívio e interações sociais positivas ou conflituosas. Neste sentido, as análises revelaram que tanto a família como a equipe do CREAS ofereceram mecanismos de 
auxílio no processo de adolescer, como, por exemplo, apoio emocional, carinho, escuta ativa, aconselhamento, regulação da conduta.

A tese apresentada propiciou conhecimento científico mais aprofundado acerca das redes sociais de adolescentes em cumprimento de medida socioeducativa LA, destacandose a importância dessas redes como um fator de proteção. Concluiu-se que uma rede social, caracterizada por vínculos fortes e diferentes membros e instituições, possibilita a regulação da conduta infracional dos adolescentes em LA, propiciando a eles, promoção social e, também, possibilidades maiores de construírem uma trajetória de vida saudável, responsável e distante do crime.

Sugere-se que os conhecimentos advindos desta tese sejam considerados na implantação de políticas públicas essenciais aos adolescentes, uma vez que pode contribuir para o direcionamento de ações na esfera da saúde coletiva, centradas no cuidado integral com vistas a buscar a (re) inserção do adolescente em LA na família e na sociedade, prevenindo-se, assim, sua reincidência no crime e no sistema socioeducativo.

Por fim, entende-se que o enfermeiro, como profissional de destaque na atenção primária à saúde, deve atuar, junto a outros profissionais de saúde e educação, no sentido de fortalecer a rede social de adolescentes em conflito com a lei. A realização de outros estudos nesse sentido pode ampliar o saber sobre o tema, buscando problematizar a inserção do enfermeiro na construção do cuidado integral aos adolescentes. 


\section{REFERÊNCIAS $^{6}$}

ALARCÃO, M.; SOUSA, L. Rede Social Pessoal: do conceito à avaliação psicológica. Phychologica, Coimbra, v. 44, p. 353-376, 2007.

ALEXANDRE, A. M. C. et al. Mapa da rede social de apoio às famílias para a promoção do desenvolvimento infantil. Revista da Escola de Enfermagem da USP, São Paulo, v. 46, n. 2, p. 272-279, 2012.

ALMEIDA, I. S.; RODRIGUES, B. M. R. D.; SIMÕES, S. M. F. O adolescer... um vir a ser. Revista Adolescência \& Saúde, Rio de Janeiro, v. 4, n. 3, p. 24-28, 2007.

AMPARO, D. M. et al. Adolescentes e jovens em situação de risco psicossocial: redes de apoio social e fatores pessoais de proteção. Estudos de Psicologia (Natal), Natal, v. 13, n. 2, p. $165-174,2008$.

ARANZEDO, A. C.; SOUZA, L. Adolescentes autores de homicídio: vivência da privação de liberdade e planos para o futuro. Revista Eletrônica de Psicologia Política, São Luis, v. 5, n. 15, p. 1-20, 2007. Disponível em: 〈http://www.psicopol.unsl.edu.ar/dic2007_nota1.pdf $>$. Acesso em: 20 dez. 2014.

ARAÚJO, I. R. L.; VIEIRA, A. S.; CAVALCANTE, M. A. S. Contribuição de Vygotsky e Bakhtin na linguagem: sentidos e significados. Revista do Programa de Pós-Graduação em Educação, Maceió, v. 1, n. 2, p. 1-14, 2009.

AYRES, J. R. C. M. et al. Vulnerability, Human Rights, and Comprehensive Health Care Needs of Young People Living With HIV/AIDS. American Journal of Public Health, Washington, v. 96, n. 6, p. 1001-1006, 2006.

BARBERET., R. et al. European Institute for Crime Prevention and Control, affiliated with the United Nations Self-reported juvenile delinquency in England and Wales, The Netherlands and Spain. Helsinki: HEUNI, p. 174, 2004. Disponível em: <http://www.heuni.fi/25461.htm>. Acesso em: 10 out. 2014.

BANACO, R. A. Adolescentes e terapia comportamental. In: RANGÉ, B. (orgs.). Psicoterapia comportamental e cognitiva: pesquisa, prática, aplicações e problemas. Campinas: Livro Pleno, 2011. p. 142-148.

BAO, W. N.; HAAS, A.; PI, Y. Life strain, coping, and delinquency in the People's Republic of China: anempirical test of general strain theory from a matching perspective in social support. International Journal Offender Therapy and Comparative Criminology, London, v. 51, n. 1, p. 9-24, 2007.

\footnotetext{
${ }^{6}$ De acordo com a Associação Brasileira de Normas Técnicas. NBR 6023
} 
BAZON, M. R. et al. Adolescentes em conflito com a lei, padrões de comportamento infracional e trajetória da conduta delituosa: um modelo explicativo na perspectiva desenvolvimental. Revista Brasileira de Adolescência e Conflitualidade, São Paulo, n. 5, p. 59-87, 2011.

BAZON, M. R.; SILVA, J. L.; FERRARI, R. M. Trajetórias escolares de adolescentes em conflito com a lei. Educação em Revista, Belo Horizonte, v. 29, n. 2, p. 175-199, 2013.

BERTOLOZZI, M. R. et al . Os conceitos de vulnerabilidade e adesão na Saúde Coletiva. Revista da Escola de Enfermagem da USP, São Paulo, v. 43, n. 2, p. 1326-1330, 2009.

BRAGA, I. F. et al. Perceptions of adolescents concerning social support provided during maternity in the context of primary care. Escola Anna Nery, Rio de Janeiro, v. 18, n. 3, p. 448-455, 2014.

BRANCO, B. M.; WAGNER, A.; DEMARCHI, K. A. Adolescentes infratores: rede social e funcionamento familiar. Psicologia: Reflexão e Crítica, Porto Alegre , v. 21, n. 1, p. 125132,2008 .

BRANCO, B. M.; WAGNER, A. Os adolescentes infratores e o empobrecimento da rede social quando do retorno à comunidade. Ciência \& Saúde Coletiva, Rio de Janeiro, v. 14, n. 2, p. 557-566, 2009.

BRASIL. Ministério da Saúde. Secretaria Executiva. Coordenação da Saúde da Criança e do Adolescente. Programa Saúde do Adolescente. Bases Programáticas. $2^{\mathrm{a}}$ ed. Brasília: Ministério da Saúde, 1996.

Ministério do Desenvolvimento Social e Combate à Fome. Conselho Nacional de Assistência Social. Caderno de Textos: Participação e Controle Social no SUAS. Brasília: CNAS/MDS, 2009a. Disponível em: <http://www.mds.gov.br/programas/rede-suas/protecaosocial-basica/programas/rede-suas $>$. Acesso em: 12 abr. 2014.

Ministério do Desenvolvimento Social e Combate à Fome. Conselho Nacional de Assistência Social. Proteção social espacial. Brasília: MDS, 2009b. Disponível em: <http://www.mds.gov.br/assistenciasocial/protecaoespecial〉. Acesso em: 12 abr. 2014.

. Ministério da Justiça. Estatuto da Criança e do Adolescente. Lei no 8069 de 13 julho de 1990. Brasília: Ministério da Justiça, p. 80, 2010.

. Ministério do Desenvolvimento Social e Combate à Fome. Censo SUAS 2010: CRAS, CREAS, Gestão Municipal, Gestão Estadual, Conselho Municipal, Conselho Estadual, Entidades Beneficentes. Brasília: MDS, Secretaria de Avaliação e Gestão da Informação; Secretaria Nacional de Assistência Social, 2011.

BRÊTAS, J. R. S. Vulnerabilidade e adolescência. Revista da Sociedade Brasileira de Enfermagem Pediátrica São Paulo, v. 10, n. 2, p. 89-96, 2010.

BRITO, L. M. T. Liberdade assistida no horizonte da doutrina de proteção integral. Psicologia: Teoria e Pesquisa, Brasília, v. 23, n. 2, p. 133-138, 2007. 
BRITO, R.; KOLLER, S. H. Desenvolvimento humano e redes de apoio social e afetivo. In: CARVALHO, A. O mundo social da criança: Natureza e cultura em ação. São Paulo: Casa do Psicólogo, 2007.

BITENCOURT, A. O. M. et al. Teias do adolescer: (re)pensando o processo de cuidar do adolescente. Ilheus: UESC, 2013. 33 p. Disponível em: $\langle$ http://www.uesc.br/nucleos/bomdevida/teias_do_adolescer.pdf $>$. Acesso em: 20 out 2014.

BUI, H. N. Parent-child conflitocts, school troubles, and difference in delinquency across imigration generation. Crime e Delinquency, Oxford, v. 55, n. 30, p. 412-441, 2009.

BULLOCK, K. Family social support. Conceptual frameworks for nursing practice to promote and protect health. In: BOMAR, P. J. Promoting health in families. Applying family research and theory to nursing practice. Philadelphia: Saunders, 2004.

CALDWELL, R. M.; WIEBE, R. P.; CLEVELAND, H. H. The influence of future certainty and contextual factors on delinquent behavior and school adjustment among African American adolescents. Journal of Youth and Adolescence. New York, v. 35, n. 4, p. 591602, 2006.

CAMPOS, D. M. S. Psicologia da adolescência: normalidade e psicopatologia. $22^{\mathrm{a}}$ ed. Petrópolis: Vozes, 2010.

CARMO, D. R. P. et al. Adolescente que cumpre medida socioeducativa: modos de ser no cotidiano e possibilidades para enfermagem. Revista Gaúcha Enfermagem, Porto Alegre, v. 32, n. 3, p. 472-478, 2011.

CASTEL, R. A discriminação negativa - Cidadãos ou autoclaves?. Petrópolis: Vozes, 2008.

CASTELlS, M.; A Era da Informação: economia, sociedade e cultura, vol. 3, São Paulo: Paz e terra, 1999. p. 411-439. Disponível em: <www.virtual.ie.ufrj.br/infoeducar/bib/castells1.doc >. Acessado em: 20 Out 2014.

CENTERS FOR DISEASE CONTROL AND PREVENTION. The following link found at the Centers for Disease Control and Prevention. Adolescent Health - Protective Factors Adolescent and School Health. Disponível em: 〈http://www.cdc.gov $>$. Acesso em: 20 mar. 2013.

CENTRO DE INTERNAÇÃO PROVISÓRIA DE PATOS DE MINAS. Relatório de gestão anual. Patos de Minas: CEIP, 2014.

CENTRO DE REFERÊNCIA ESPECIALIZADO DE ASSISTÊNCIA SOCIAL. Relatório monitoramento de acompanhamento dos adolescentes em LA (abril, maio e junho/2014). Patos de Minas: 2014.

As COCCO, M.; LOPES, M. J. M. Violência entre jovens: dinâmicas sociais e situações de vulnerabilidade. Revista Gaúcha Enfermagem, Porto Alegre, v. 31, n. 1, p. 151-159, 2010. CONTE, M. Desafios na Juventude: drogas, consumismo e violências. Educação e Realidade, Porto Alegre, v. 33, n. 2, p. 131-146, 2008. 
CORRADI-WEBSTER, C. M.; ESPER, L. H.; PILLON, S. C. A enfermagem e a prevenção do uso indevido de drogas entre adolescentes. Acta Paulista de Enfermagem, São Paulo, v. 22, n. 3, p. 331-334, 2009.

COSTA, C. R. B. S. F.; ASSIS, S. G. Fatores protetivos a adolescentes em conflito com a lei no contexto socioeducativo. Psicologia \& Sociedade, Belo Horizonte, v. 18, n. 3, p. 74-81, 2006.

COSTA, L. G. A rede de apoio social de jovens em situação de vulnerabilidade social e o uso de drogas. 2009. 93 f. (Tese) - Universidade Federal do Rio Grande do Sul, Instituto de Psicologia, Porto Alegre, 2009.

COSTA, R. P.; ALÍPIO, S. Trabalho compulsório? O sentido do trabalho para os jovens que cumprem a Medida de Prestação de Serviço a Comunidade - PSC. Pesquisas e Práticas Psicossociais, São João del-Rei, v. 4, n. 2, p. 205-212, 2010.

D’ANDREA, G.; VENTURA, C. A. A.; COSTA JUNIOR, M. L. Uso socializado de álcool por adolescentes ofensores: um enfoque fundamentado nas necessidades humanas. Revista da Escola de Enfermagem da USP, São Paulo, v. 48, n. 1, p. 135-143, 2014 .

DAVIM, R.M.B. et al. Adolescente/adolescência: Revisão Teórica Sobre Uma Fase Critica da Vida. Revista Rene, Fortaleza, v. 10, n. 2, p. 131-140, 2009.

DAVOGLIO, T. R.; GAUER, G. J. C. Adolescentes em conflito com a lei: aspectos sociodemográficos de uma amostra em medida socioeducativa com privação de liberdade. Contextos Clínicos, São Leopoldo, v. 4, n. 1, p. 42-52, 2011.

DE ANTONI, C.; KOLLER, S. H.. Vulnerabilidade e resiliência familiar: um estudo com adolescentes que sofreram maus tratos intrafamiliares. Psico, Porto Alegre, v. 31, n. 1, p. 39$66,2000$.

DESTRO, C. M. A.; SOUZA, L. A. P. Linguagem oral e escrita em adolescentes infratores institucionalizados. Revista CEFAC, São Paulo, v. 14, n. 6, p. 1020-1027, 2012.

DEZOTI, A. P. et al. Rede social de apoio ao desenvolvimento infantil segundo a equipe de saude da familia. Escola Anna Nery, Rio de Janeiro, v. 17, n. 4, p. 721-729, 2013.

DIB, M. A.; BAZON, M. R.; SILVA, J. L. Família e conduta infracional na adolescência: revisão sistemática da literatura. Perspectivas em Psicologia, Uberlândia, v. 16, n. 1, p. 142$159,2012$.

DONG, B; KROHN, M. D. Exploring Intergenerational Discontinuity in Problem Behavior: Bad Parents With Good Children. Youth Violence and Juvenile Justice, Denton, v. 13, n. 2, p. 99-12, 2015..

EISENSTEIN, E. Adolescência: definições, conceitos e critérios. Revista Adolescência \& Saúde, v. 2, n. 2, p. 6-7, 2005.

FEIJÓ, M. C.; ASSIS, S. G. O contexto de exclusão social e de vulnerabilidades de jovens infratores e de suas famílias. Estudos de Psicologia, Campinas, v. 9, n. 1, p. 157-166, 2004. 
FEREIRA, M. B. et al. Social support, socioeconomic and clinical risk: comparison between to neighborhoods in a Brazilian upcountry town. Revista da Escola de Enfermagem da USP, São Paulo, v. 46, n. 4, p. 822-828, 2012.

FERNANDES, A. C.; FERREIRA, K. R.; CABRAL, S. M. S. C. O papel do enfermeiro na saúde do adolescente. In: Congresso de Iniciação Científica das Faculdades Integradas de Ourinhos, 8, 2011, Ourinhos-SP, Anais do Congresso de Iniciação Científica das Faculdades Integradas de Ourinhos. Disponível em: < fio.edu.br/cic/anais/2009viiicic/ Artigos/07/07.48.pdf>. Acesso em: 10 out. 2014.

FONSECA, F. F. et al. As vulnerabilidades na infância e adolescência e as políticas públicas brasileiras de intervenção. Revista Paulista de Pediatria, São Paulo, v. 31, n. 2, p. 258-264, 2013.

FISCHER, C. To dwell among friends: personal network in town and city. Chicago: University of Chicago Press, 1982.

FLICK, U. Qualidade na pesquisa qualitativa. Porto Alegre: Artmed, 2009. 168 p.

FUNDO DAS NAÇÕES UNIDAS PARA A INFÂNCIA. O direito de ser adolescente: Oportunidade para reduzir vulnerabilidades e superar desigualdades. Fundo das Nações Unidas para a Infância. - Brasília: UNICEF, p. 182, 2011. Disponível em: <http://www.unicef.org/brazil/pt/br_sabrep11.pdf >. Acesso em: 20 set. 2014.

GALLO, A. E.; WILLIAMS, L. C. A. A escola como fator de proteção à conduta infracional de adolescentes. Cadernos de Pesquisa, São Paulo, v. 38, n. 133, p. 41-59, 2008.

GOMES, R. Análise e interpretação de dados de pesquisa qualitativa. In: MINAYO, M. C. S. (Org.). Pesquisa social: teoria, método e criatividade. $28^{a}$ ed. Petrópolis: Editora Vozes, 2009, p. 79-108.

Pesquisa qualitativa em saúde. São Paulo: Instituto Sírio-Libanês de Ensino e Pesquisa, 2014. 45 p.

GOMES, R. et al. Organização, processamento, análise e interpretação de dados: o desafio da triangulação. In: MINAYO, M. C. S.; ASSIS, S. G.; SOUZA, E. R. (Org.). Avaliação por triangulação de métodos: abordagem de programas sociais. Rio de Janeiro: Fiocruz, 2005, p. 185-221.

GUERRA, A. M. C. et al. Construindo idéias sobre a juventude envolvida com a criminalidade violenta. Estudos e Pesquisas em Psicologia, Rio de Janeiro, v. 10, n. 2, p. 434-456, 2010.

GOSWAMI, H. Social Relations hips and children's subjective well-being. Social Indicators Research, Oxford, v. 107, n. 3, p. 575-588, 2011.

GIACOMOZZI, C. M.; LACERDA, M. R. A prática da assistência domiciliar dos profissionais da estratégia de saúde da família. Texto \& Contexto - Enfermagem, Florianópolis, v. 15, n. 4, p. 645-653, 2006. 
HIGARASHI, I. H. et al. Ações desenvolvidas pelo enfermeiro junto aos adolescentes no Programa Saúde da Família em Maringá/Paraná. Revista Rene, Fortaleza, v. 12, n. 1, p. 127$135,2011$.

INSTITUTO BRASILEIRO DE GEOGRAFIA E ESTATÍSTICA. Censo Demográfico e Contagem da População. 2011. Disponível em: <http://www.sidra.ibge. gov.br/bda/tabela/listabl.asp?c=1378\&z=cd\&o=7>. Acesso em: 20 fev. 2013.

JACOBINA, O. M. P.; COSTA, L. F. "Para não ser bandido": Trabalho e adolescentes em conflito com a lei. Cadernos de Psicologia Social do Trabalho, São Paulo, v. 10, n. 2, p. 95$110,2007$.

JAMES. K. BUNCH, J. CLAY-WARNER. J. Perceived Injustice and School Violence: An Application of General Strain Theory. Youth Violence and Juvenile Justice. 13:169-189. 2015. Disponível em: <http://yvj.sagepub.com/content/13/2/169.abstract>. Acesso em: 22 mar. 2015.

KANTORSKI, L. C. et al. A atuação do Enfermeiro nos Centros de Atenção Psicossocial à luz do Modo Psicossocial. Revista Mineira de Enfermagem. v. 14, n. 3, p. 399-407, 2010.

LE BLANC, M. A Generic Control Theory of the Criminal Phenomenon: The Structural and the Dynamical Statements of Integrative Multilayered Control Theory. In: THORNBERRY, T. P. Developmental Theories of Crime and Delinquency. Advances in Theoretical Criminology, v. 7, p. 215-286. New Bruns-wick: Transaction, 1997.

Trajetórias de delinquência comum, transitória e persistente: uma estratégia de prevenção diferencial. In: ALBERTO I. (org.) Comportamento Antissocial: Escola e Família. Coimbra: Centro de Psicopedagogia da Universidade de Coimbra, 2003. p. 31-80.

Self-control and social control of deviant behavior in context: development and interactions along the life course. In: WIKSTROM, P. O. H.; SAMPSON, R. J. (Orgs.). The Explanation of Crime Context, Mechanisms, and Development. New York: Cambridge University Press, p. 124-151, 2006.

MARTINS, P. Protecção de Crianças e Jovens em Itinerários de Risco: Representações, Espaços e Modos. 2004. 493 f. Tese (Doutoramento em Estudos da Criança) - Instituto de Estudo da Criança, Universidade do Minho, Braga, Portugal, 2004.

MENDES, E. A. S. M. Redes Sociais Pessoais e Percepção da Qualidade de Vida das Crianças e Jovens Institucionalizados - O papel das Famílias Amigas. 2011. 50 f. Tese (Mestrado Integrado em Psicologia, Área de Especialização em Psicologia da Justiça Trabalho) - Universidade do Minho,Braga, Portugal, 2011.

MINAS GERAIS. Levantamento sobre os índices de violência escolar no Estado de Minas Gerais. Audiência Pública. Belo Horizonte: Assembleia Legislativa (ALMG), 2011.

Manual de metodologia das medidas socioeducativas em meio aberto. Secretaria de Estado de Defesa Social. Subsecretaria de Atendimento às Medidas Socioeducativas, Belo Horizonte, MG. 2013. 
MINAYO, M. C. S. O desafio do conhecimento: pesquisa qualitativa em saúde. 12. ed. São Paulo: Hucitec, 2010.

MONTEIRO, E. M. L. M. et al. Desafios e perspectivas na reeducação e ressocialização de adolescentes em regime de semi-liberdade: subsídios para Enfermagem. Revista de Enfermagem Referência, Coimbra, v. serIII, n. 3, 2011.

MORAIS, K. R. F. Rede de apoio social de adolescentes em conflito com a lei. 2012.98 f. Dissertação (Mestrado). -. Universidade de Fortaleza, Fundação Edson de Queiroz. Fortaleza, 2012.

MOREIRA, M. C.; SARRIERA, J. C. Satisfação e composição da rede de apoio social a gestantes adolescentes. Psicologia em Estudo, Maringá, v. 13, n. 4, p. 781-789, 2008.

MOTA, C.; MATOS, P. Adolescência e institucionalização numa perspectiva de vinculação. Psicologia \& Sociedade, Florianópolis, v. 20, n. 3, p. 367-377, 2008.

MULLER, F. et al. Perspectivas de adolescentes em conflito com a lei sobre o delito, a medida de internação e as expectativas futuras. Revista Brasileira Adolescência e Conflitualidade, São Paulo, v. 1, n. 1, p. 70-87, 2009.

NARDI, F. L. Adolescentes em conflito com a lei: percepções sobre família, ato infracional e medida socioeducativa. 2010. 97 f. Dissertação (Mestrado em Psicologia) - Instituto de Psicologia, Universidade Federal do Rio Grande do Sul, Porto Alegre, 2010.

NARDI, F. L.; DELl'AGLIO, D. D. Delinquência juvenil: uma revisão teórica. Acta Colombiana de Psicología, Bogotá, v. 13, n. 2, p. dez. 2010.

Adolescentes em conflito com a lei: percepções sobre a família. Psic.: Teor. e Pesq., Brasília, v. 28, n. 2, jun. 2012.

NUNES, M. R. et al. Famílias em risco socioeconômico e clínico e o apoio social. Revista da Sociedade Brasileira de Enfermeiros Pediatras, São Paulo, v. 10, n. 2, p. 79-88, 2010.

NUNES, M. C. A.; ANDRADE, A. G. S.; MORAIS, N. Adolescentes em conflito com a lei e família: um estudo de revisão sistemática da literatura. Contextos Clínicos, São Leopoldo, v. 6, n. 2, p. 144-156, 2013.

OLIVEIRA, T. C.; CARVALHO, L. P.; SILVA, M. A. O enfermeiro na atenção à saúde sexual e reprodutiva dos adolescentes. Revista Brasileira de Enfermagem, Brasília, v. 61, n. 3, p. 306-311, 2008.

OLIVEIRA, T. P. et al. Meninas da luz: uma abordagem da enfermagem na gravidez na adolescência. Revista do Instituto de Ciências da Saúde, São Paulo, v. 27, n. 2, p. 122-127, 2009.

ORGANIZAÇÃO MUNDIAL DA SÁUDE. Adolescent health epidemiology. Department of Maternal. 2014. Disponível em: <http://www.who.int/maternal_child adoles cen t/e pidemiology/adolescence/en/>. Acesso em: 20 set. 2014. 
PEDRO, I. C. S.; ROCHA, S. M. M.; NASCIMENTO, L. C. Apoio e rede social em enfermagem familiar: revendo conceitos. Revista Latino-Americana Enfermagem, Ribeirão Preto, v. 2, n. 16, p. 324-327, 2008.

PINHEIRO, A. Criança e adolescente no Brasil: porque o abismo entre a lei e a realidade. Fortaleza: Universidade Federal do Ceará, 2006.

POLETTO, M.; KOLLER, S. H. Contextos ecológicos: promotores de resiliência, fatores de risco e de proteção. Estudos psicologia, Campinas, v. 25, n. 3, p. 405-416, 2008.

PRIOTTO. E. M. T. P. Violência envolvendo adolescentes estudantes na tríplice fronteira: Brasil - Paraguai - Argentina. 2013. 252 f. Tese (Doutorado em Ciências).. Escola de Enfermagem de Ribeirão Preto, Universidade de São Paulo, Ribeirão Preto, 2013.

PROGRAMA DAS NAÇÕES UNIDAS PARA O DESENVOLVIMENTO, 2010. Disponivel em: 〈http://www .pn ud.org.br/atlas/ranking/Ranking-IDHM-Municipios-2010.aspx>.

Acesso: 10 fevereiro de 2014.

SARAIVA, J. B. C. Adolescente em conflito com a lei: da indiferença à proteção integral. Uma abordagem sobre a responsabilidade penal juvenil. Porto Alegre: Livraria do Advogado, 2009.

SCHNEIDER, A. C. N.; RAMIRES, V. R. R. Vínculo parental e rede de apoio social: relação com a sintomatologia depressiva na adolescência. Aletheia, Canoas, n. 26, p. 95-108, 2007.

SCHOEN-FERREIRA, T. H.; AZNAR-FARIAS, M.; SILVARES, E. F. M. Adolescência através dos séculos. Psicologia: Teoria e Pesquisa. Brasília, v. 26, n. 2, p. 227-234, 2010.

SENA, I. J; MACHADO, T. R. C.; COELHO, M. T. A. D. A delinquência juvenil e suas relações com a função paterna. Revista Seminário Estudantil de Produção Acadêmica. Salvador, v. 10, n. 1, p. 1-11, 2007.

SILVA, M. A. I. Adolescence: Resignify it tounderst and it andact. Journal of Nursing UFPE OnLine, Recife, v. 6, n. 3, 2012. Disponível em: $<$ http://www.revista.ufpe.br/revistaenfermagem/index.php/revista/article/view/2646>. Acesso em: 2 out. 2014.

SILVA, M. A. I. et al. Vulnerabilidade na saúde do adolescente: questões contemporâneas. Ciência \& Saúde Coletiva, Rio de Janeiro, v. 19, n. 2, 2014.

SILVEIRA, R. C. C. Adolescente e ato infracional. 2009. 22 f. Monografia (Curso de Direito), Escola de Direito e Relações Internacionais, Faculdades Integradas do Brasil, 2009.

SIQUEIRA, A.; DELL'AGLIO, E. Crianças e Adolescentes Institucionalizados: Desempenho Escolar, Satisfação de Vida e Rede de Apoio Social. Psicologia: Teoria e Pesquisa, v. 26, n. 3, p. 407-415, 2010

SLUZKI, C. E. A Rede Social na Prática Sistêmica. São Paulo, Casa do Psicólogo, 1997. 
A Rede Social na Prática Sistêmica: alternativas terapêuticas. $3^{\text {a }}$ ed. São Paulo: Casa do Psicólogo, 2006.

. Redes pessoais sociais e saúde: implicações conceituais e clínicos de seu impacto recíproco. Famílias, Sistemas \& Saúde. v. 28, n. 1, p. 1-18, 2010.

SOUSA, L. E. E. M.; ALMEIDA, R. O. Sob o signo do medo: o significado da Liberdade Assistida na vida de adolescentes em conflito com a lei. Revista PLURAL, São Paulo, v. 18, n. 2, p. 27-51, 2011.

SOUSA, L. E. E. M. Sob o fio da navalha: percepções de adolescentes em conflito com a lei sobre a medida sócio-educativa de liberdade assistida. 2010. 164 f. (Tese) - Universidade Estadual do Ceará, Fortaleza, Ceará, 2010.

STOUTHAMER-LOEBER, M. et al. Desistance from persistent serious delinquency in the transition to adulthood. Development and Psychopathology, New York, v. 16, n. 4, p. 897918, 2004.

TOMÉ, S. M. G. et al. Morfologia e papel das redes sociais no processo de reintegração social de apenados. Revista Brasileira de Economia Doméstica, Viçosa, v. 23, n. 1, p. 147-169, 2012.

UDE, W.; FELIZARDO JUNIOR, L. C. Enfrentamento à violência, configurações e redes sociais: possibilidades teórico-metodológicas para a realização de intervenções. In: SANTOS, G. L. (org.). et al. Escola, violência e redes sociais. Belo Horizonte: FAE/UFMG, p. 164, 2009.

WAISELFISZ, J. J. Mapa da violência 2014: Os jovens do Brasil. Brasília: Presidência da República, 2014.

WATTS, S. J.; MCNULTY, T. L. Delinquent Peers and Offending: Integrating Social Learning and Biosocial Theory. Youth Violence and Juvenile Justice, Denton, v. 13, n. 2, p. 190-206, 2015. Disponivel em: <http://yvj.sagepub.com/content/13/2/190.abstract>.Acesso em: 22 mar. 2015.

WESTRUPP, D. Adolescentes em conflito com a lei e as medidas socioeducativas no município de Joinville (SC). 2010. 171 f. (Dissertação) - Universidade do Vale do Itajaí, Itajaí, 2010.

ZAPPE, J. G.; DIAS, A. C. G. Violência e fragilidades nas relações familiares: refletindo sobre a situação de adolescentes em conflito com a lei. Estudos de Psicologia (Natal), Natal, v. 17, n. 3, p. 389-395, 2012.

ZHANG, D. et al. Truancy offenders in the juvenile justice system: a multicohort study. Behavioral Disorders, Reston, v. 35, n. 3, p. 229-242, 2010. 


\section{APÊNDICE A}

Roteiro para a entrevista semiestruturada

Número da entrevista:

Data:

Início/h:

Término/h:

\section{$1^{\mathrm{a}}$ - CARACTERIZAÇÃO SÓCIODEMOGRÁFICA}

1. Sexo: F ( ) M ( ) 2. Idade:

3. Cor / etnia:

4. Religião: católica ( ) evangélica ( ) espírita ( ) outras ( )

5. Moradia: própria família ( ) alugada ( ) cedida ( ) outro ( )

6. Reside com: pais ( ) o pai ( ) a mãe ( ) o responsável

( ) Outros especificar:

7. Estado civil: ( ) solteiro ( ) casado

8. Possui filhos? Não ( ) sim ( )

9. Composição familiar do grupo com quem reside:

\begin{tabular}{|l|l|l|l|l|}
\hline Parentesco & Idade & Escolaridade & Ocupação & $\begin{array}{l}\text { Renda ( Especificar em } \\
\text { salario mínimo) }\end{array}$ \\
\hline & & & & \\
\hline & & & & \\
\hline & & & & \\
\hline & & & & \\
\hline & & & & \\
\hline & & & & \\
\hline
\end{tabular}

\section{Escola}

10. Você estuda? Sim ( ) Não ( )

11. Ano escolar que frequenta?

12. Já repetiu algum ano escolar?

\section{Trabalho}

13. Você trabalha? Sim ( ) Não ( )

\section{Medida de proteção}

14. Há quanto tempo cumpre medida de LA (meses)? Qual o motivo?

15. Quais atividades que você realiza na medida de LA?

Você gosta?

Por quê? 


\section{$2^{\mathrm{a}}$ - ROTEIRO TEMATICO}

\section{Questões norteadoras}

1-Conte-me como e para você a experiência de estar cumprindo a medida LA?

2- O que te ajuda, hoje, no cumprimento da medida LA?

3-O que te ajuda a enfrentar as dificuldades ou os seus problemas do seu dia a dia? De quem ou do que recebe esta ajuda? Como e essa ajuda?

4- O que esta ajuda significa para você?

6- O que você pensa sobre esta ajuda que recebe? O que você espera desta ajuda?

5- Quais são as contribuições que esta ajuda lhe oferece?

7- Você gostaria de receber outros tipos de ajuda? Que tipo?

8- O que você pensa sobre a experiência de trabalhar?

9- Conte-me o que você acha que poderia ajudar os adolescentes a evitarem a recidiva do ato infracional?

Todas as questões terão o intuito de ampliar a compreensão das características da estrutura, da função e do tipo de vinculo da rede social dos adolescentes em LA. 


\section{APÊNDICE B}

Construção do mapa de rede social do adolescente

Para a construção do mapa foi utilizado uma cópia do mapa de rede social e lápis para os adolescentes registrarem a identificação dos sujeitos e instituições pertencentes a sua rede social. Os adolescentes em LA são questionados sobre: 1) quem são as pessoas e ou instituições mais importantes de sua vida; 2) o que você pensa sobre as pessoas da sua rede social; 3) se existe o desejo de mudança na sua rede; 4 )sobre as semelhanças das pessoas de sua rede e o adolescente; 4) definir as características estruturais da rede (tamanho, densidade, dispersão); 5) caracterizar os tipos de vínculos da rede social (significativo, fragilidade, rompido); 6) definir o tipo de função de cada membro da rede social (companhia social, apoio emocional, guia cognitivo e conselhos, regulação e controle social, ajuda material e de serviços).

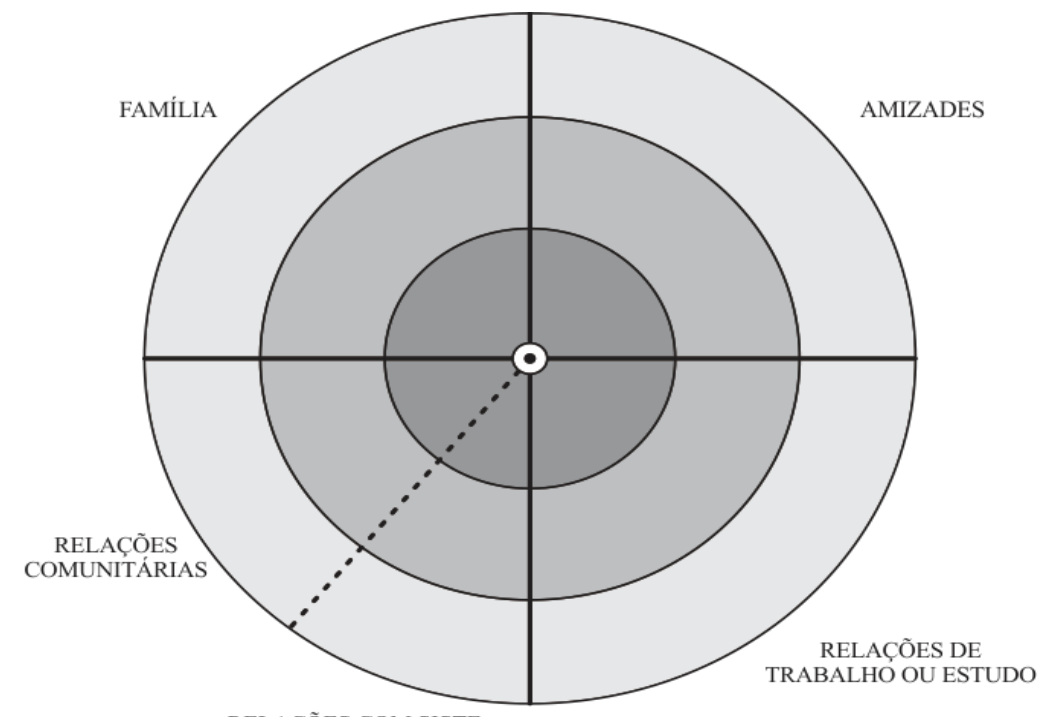

RELAÇÕES COM SISTE-

MA DE SAUDE E AG
CIAS SOCIAIS

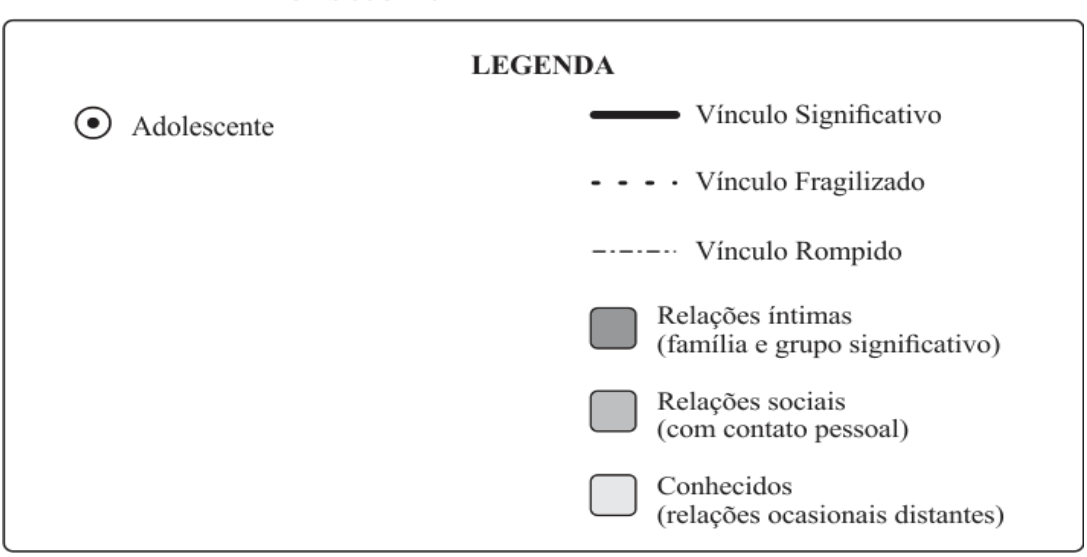

Figura 2 - Modelo de Mapa de Rede Social proposto por Sluzki (2010) 


\begin{abstract}
APÊNDICE C
Termo de consentimento livre e esclarecido para adolescentes maiores de 18 anos

Título: "Rede social: contribuições a adolescentes em liberdade assistida"

Pesquisadora responsável: Marilene Rivany Nunes

Orientadora: Profa. Dra. Marta Angélica Iossi Silva
\end{abstract}

Prezado (a),

Convidamos você para participar da pesquisa denominada "Rede social de adolescentes em liberdade assistida: um estudo exploratório". Este estudo tem como objetivo identificar e analisar a rede social dos adolescentes que cumprem a medida socioeducativa liberdade assistida (LA), para entender melhor quais são as pessoas ou instituições que ajudam ou não o adolescente em LA a enfrentar as dificuldades do dia a dia.

Salientamos que a pesquisa se dará por meio de entrevista individual e pela construção de um desenho gráfico, e para isto, você contará com a ajuda da pesquisadora, onde você poderá demostrar quais são as pessoas ou instituições que lhe dão apoio no cumprimento da medida LA. O tempo necessário para entrevista será de aproximadamente de 40 minutos e será realizada em local e horário de sua escolha. A entrevista será registrada em impresso próprio, gravada e transcrita pela pesquisadora, não trazendo nenhum custo financeiro, risco físico, moral ou vantagens financeiras para você. Sua identificação será mantida em segredo, ou seja, durante a entrevista ou a elaboração do desenho, você não irá ser identificado por nome, apelido ou qualquer outro meio.

Sua participação será voluntaria e você poderá esclarecer se necessário qualquer dúvida ou mesmo desistir de participar da pesquisa a qualquer momento, sem qualquer problema, nem mesmo comprometimento do seu atendimento no serviço do Centro de Referência Especializado de Assistência Social- Patos de Minas (CREAS).

Assim sendo, as informações coletadas serão utilizadas somente para este estudo. Os dados e instrumentos utilizados na pesquisa ficarão arquivados com o pesquisador responsável por um período de 5 anos, e após esse tempo serão destruídos.

A sua participação será importante para auxiliar na identificação de quais pessoas e ou instituições que ajudam os adolescentes no dia a dia frente à condição da LA e, consequentemente, ajudar outros adolescentes que cumprem essa medida. Assim a pesquisa poderá contribuir para identificar mecanismos que podem atuar como fonte de proteção a adolescente nesta situação. Nós poderemos aprender muito com as experiências que nos forem contadas, melhorando o cuidado que os enfermeiros e outros profissionais de saúde possam oferecer a esses adolescentes.

Este Termo de Consentimento Livre Esclarecido possui duas vias que deverão ser assinada por você e pela pesquisadora, sendo que uma via ficará com a pesquisadora e a outra entregue a você para seu conhecimento.

Esta pesquisa foi analisada e aprovada pelo Comitê de Ética em Pesquisa com Seres Humanos (CEP) da Escola de Enfermagem de Ribeirão Preto (EERP) da Universidade de São Paulo-USP, pois respeita as questões éticas necessárias para a sua realização.

Se tiver alguma dúvida, poderá nos perguntar ou entrar em contato conosco por meio do endereço ou telefone abaixo. Assim, se for necessário, entre em contato com este CEP pelo telefone (16) 3602-3380 ou no endereço Av. Bandeirantes, $n^{0} 3900-$ Ribeirão Preto(SP), no horário de 08:30 as 17:00 hs. Caso deseje falar com a pesquisadora, você poderá encontrá-la por meio do telefone (34) 9103-8038 ou na Faculdade do Curso de Enfermagem 
do UNIPAM, na Rua Major Gote n $^{\circ} 808$, Patos de Minas (MG), no horário de 19:00 as 22:30 ou pelo e-mail: maryrivany@yahoo.com.br.

Agradecemos a sua colaboração!

Após ter conhecimento sobre como poderei colaborar com esta pesquisa, concordo com a minha participação nesta pesquisa, não tendo sofrido nenhuma pressão para tanto.

$\mathrm{Eu}$

identificação__ concordo em participar desta pesquisa, contribuindo com entendimento sobre as questões apresentadas. Estou ciente de que quando não quiser mais participar, poderei desistir. Sei, também, que ao final desta pesquisa, o meu nome será mantido em segredo. Recebi uma cópia deste documento, assinada pela pesquisadora responsável e tive a oportunidade de discuti-lo com a mesma.

Assinatura do adolescente:

Patos de Minas, de de 20

Grata,

Marilene Rivany Nunes

Doutoranda - $\mathrm{N}^{\mathrm{O}}$ USP 73.620.60

Rua Major Gote $\mathrm{n}^{\mathrm{0}} 808$, Patos de Minas (MG )

Telefone: (34) 9103-8038
Proaf.Dra. Marta Angélica Iossi Silva

$\mathrm{N}^{\mathrm{o}}$ USP: 1.571.591-EERP-USP

Av Bandeirantes,3900-Campus USP

Telefone: (16) 3602-34-13 


\section{APÊNDICE D}

Termo de consentimento livre e esclarecido para pais ou responsável pelo adolescente menor de 18 anos

Título: "Rede social: contribuições a adolescentes em liberdade assistida"

Pesquisadora responsável: Marilene Rivany Nunes

Orientadora: Profa. Dra. Marta Angélica Iossi Silva

Prezado(a) Senhor(a),

Por meio deste, gostaríamos de solicitar a sua autorização para o seu filho (a) participar da realização da pesquisa denominada "Rede social de adolescentes em liberdade assistida: um estudo exploratório". Este estudo será realizado pela pesquisadora Marilene Rivany Nunes sob orientação da Profa. Dra. Marta Angélica Iossi Silva, da Escola de Enfermagem de Ribeirão Preto / USP, e tem como objetivo identificar e analisar a rede social dos adolescentes que cumprem a medida socioeducativa liberdade assistida (LA).

Nesta pesquisa seu filho (a), o (a) adolescente, será entrevistado individualmente pela pesquisadora e juntos irão construir um desenho, onde poderá demostrar quais são as pessoas, instituições que o ajudam no dia a dia. Seu filho (a) estará acompanhado pela pesquisadora Marilene Rivany Nunes, que estará disponível para tirar suas dúvidas e ouvir suas sugestões de mudança ou algum comentário sobre a pesquisa. O tempo necessário para entrevista e elaboração do desenho será de aproximadamente 40 minutos e será realizada em local e horário de escolha do adolescente. A entrevista será registrada, gravada e transcrita pela pesquisadora, não trazendo nenhum custo financeiro, risco físico, moral ou vantagem financeiro para você e seu filho (a). A identificação de seu filho (a) será mantida em segredo, ou seja, durante a entrevista ou a elaboração do desenho, seu filho (a) não irá ser identificado por nome, apelido ou qualquer outro meio.

Assim sendo, as informações serão usadas apenas para este estudo. Os dados e instrumentos utilizados na pesquisa ficarão arquivados com o pesquisador responsável por um período de 5 anos, e após esse tempo serão destruídos.

A participação deste estudo será voluntaria e você e ou o seu filho (a) poderá esclarecer se necessário qualquer dúvida ou mesmo desistir de participar da pesquisa a qualquer momento sem qualquer problema, nem mesmo comprometimento do atendimento de seu filho (a) no serviço do Centro de Referência Especializado de Assistência Social- Patos de Minas (CREAS).

A autorização para seu filho participar desta pesquisa será importante para auxiliar na identificação de quais pessoas e ou instituições que ajudam seu filho no dia a dia frente à condição da LA e, consequentemente, ajudar outros adolescentes que cumprem essa medida. Assim a pesquisa poderá contribuir para identificar mecanismos que podem atuar como fonte de proteção a adolescente nesta situação. Nós poderemos aprender muito com as experiências que nos forem contadas, melhorando o cuidado que os enfermeiros e outros profissionais de saúde possam oferecer a esses adolescentes.

Este termo possui duas vias que deverão ser assinada por você responsável e a pesquisadora, sendo que uma via ficará com a pesquisadora e a outra será entregue ao responsável do adolescente para conhecimento.

Se você, pai ou responsável pelo adolescente, concordar em autorizar seu filho (a) a participar desta pesquisa, por favor, assine estás duas via do Termo de Consentimento Livre 
e Esclarecido após todos os esclarecimentos e entregue à pesquisadora que for entrevistá-lo (a). Vocês, pais ou responsável, receberá uma cópia assinada. Será, também, apresentado a seu filho (a) o Termo de Assentimento, contendo informações sobre os objetivos, justificativas, procedimentos executados na pesquisa. O mesmo terá duas vias que devera ser assinado pela pesquisadora e pelo seu filho (a), sendo que uma via ficara com a pesquisadora e a outra será entregue ao seu filho (a) para conhecimento.

Esta pesquisa foi analisada e aprovada pelo Comitê de Ética em Pesquisa com Seres Humanos (CEP) da Escola de Enfermagem de Ribeirão Preto (EERP) da Universidade de São Paulo-USP, pois respeita as questões éticas necessárias para a sua realização.

Se tiver alguma dúvida, poderá nos perguntar ou entrar em contato conosco por meio do endereço ou telefone abaixo. Assim, se for necessário, entre em contato com este CEP pelo telefone (16) 3602-3380 ou no endereço Av. Bandeirantes, $n^{\mathrm{o}} 3900$ - Ribeirão Preto (SP), no horário de 08:30 as 17:00 hs. Caso deseje falar com a pesquisadora, você poderá encontrá-la por meio do telefone (34) 9103-8038 ou na Faculdade do Curso de Enfermagem do UNIPAM, na rua Major Gote $n^{\circ}$ 808, Patos de Minas (MG), no horário de 19:00 as 22:30 ou pelo e-mail: maryrivany@yahoo.com.br.

Agradecemos a sua colaboração!

Após ter conhecimento sobre como poderei colaborar com esta pesquisa, concordo com a participação de meu filho (a) nesta pesquisa, não tendo sofrido nenhuma pressão para tanto.

$\mathrm{Eu}$, ,identificação

autorizo meu filho(a) a participar

desta pesquisa, contribuindo com entendimento sobre as questões apresentadas. Estou ciente de que quando não quiser mais participar, meu (minha) filho (a) poderá desistir. Sei, também, que ao final desta pesquisa, o nome do(a) meu filho(a) será mantido em segredo. Recebi uma cópia deste documento, assinada pela pesquisadora responsável e tive a oportunidade de discuti-lo com a mesma.

Assinatura dos pais ou responsável pelo (a) adolescente:

Patos de Minas, de de 20

Grata,

Marilene Rivany Nunes

Doutoranda - $\mathrm{N}^{\mathrm{O}}$ USP 73.620.60

Rua Major Gote ${ }^{\circ} 808$, Patos de Minas (MG )

Telefone: (34) 602-34-13
Profa. Dra. Marta Angélica Iossi Silva

$\mathrm{N}^{\mathrm{o}}$ USP: 1.571.591-EERP-USP

Av Bandeirantes,3900-Campus USP

Telefone: (16) 3602-34-13 


\section{APÊNDICE E}

Termo de assentimento para o adolescente menor de 18 anos

Título: "Rede social: contribuições a adolescentes em liberdade assistida"

Pesquisadora responsável: Marilene Rivany Nunes

Orientadora: Profa. Dra. Marta Angélica Iossi Silva

Você está sendo convidado (a) como voluntário (a) a participar da pesquisa "Rede social de adolescentes em liberdade assistida: um estudo exploratório". Este estudo será realizado pela pesquisadora Marilene Rivany Nunes sob orientação da Profa. Dra. Marta Angélica Iossi Silva, da Escola de Enfermagem de Ribeirão Preto / USP, e tem como objetivo identificar e analisar a rede social dos adolescentes que cumprem a medida socioeducativa liberdade assistida (LA). O motivo que nos leva a estudar esse assunto é a necessidade de entender quem ajuda ou não o adolescente em LA a enfrentar as dificuldades do dia a dia.

Para este estudo adotaremos o(s) seguinte(s) procedimento(s): uma entrevista individual e a construção de um desenho da rede social, e para isto, você contara com a ajuda da pesquisadora onde você poderá demostrar quais são as pessoas ou instituições que lhe dão apoio no cumprimento da medida LA. O tempo necessário para entrevista será de aproximadamente de 40 minutos e será realizada em local e horário de sua escolha. A entrevista será registrada em impresso próprio, gravada e transcrita pela pesquisadora, não trazendo nenhum custo financeiro, risco físico e moral e nem vantagem financeira para você. Sua identificação será mantida em segredo, ou seja, durante a entrevista ou a elaboração do desenho, você não irá ser identificado por nome, apelido ou qualquer outro meio.

Para participar deste estudo, o responsável por você deverá autorizar e assinar um Termo de Consentimento Livre Esclarecido. Você será esclarecido (a) em qualquer aspecto a qualquer momento sobre o que desejar e estará livre para participar ou recusar-se. O responsável por você poderá retirar o consentimento ou interromper a sua participação a qualquer momento. A sua participação é voluntária e a recusa em participar não acarretará qualquer penalidade ou modificação na forma em que é atendido (a) pelo CREAS. Você não será identificado em nenhuma publicação. Este estudo apresenta risco mínimo (ou risco maior que o mínimo, se for o caso), isto é, o mesmo risco existente em atividades rotineiras como conversar, tomar banho, ler etc. Apesar disso, você tem assegurado o direito a ressarcimento ou indenização no caso de quaisquer danos eventualmente produzidos pela pesquisa.

Os resultados estarão à sua disposição quando finalizada. Os dados e instrumentos utilizados na pesquisa ficarão arquivados com o pesquisador responsável por um período de 5 anos, e após esse tempo serão destruídos.

Este termo de assentimento encontra-se impresso em duas vias que devera ser assinado por você e pela pesquisadora, sendo que uma via ficará com você e a outra com a pesquisadora responsável.

Esta pesquisa foi analisada e aprovada pelo Comitê de Ética em Pesquisa com Seres Humanos (CEP) da Escola de Enfermagem de Ribeirão Preto (EERP) da Universidade de São Paulo-USP, pois respeita as questões éticas necessárias para a sua realização.

Se tiver alguma dúvida, poderá nos perguntar ou entrar em contato conosco por meio do endereço ou telefone abaixo. Assim, se for necessário, entre em contato com este CEP pelo telefone (16) 3602-3380 ou no endereço Av. Bandeirantes, $n^{0} 3900-$ Ribeirão Preto(SP), no horário de 08:30 as 17:00 hs. Caso deseje falar com a pesquisadora, você poderá encontrá-la por meio do telefone (34)9103-8038 ou na Faculdade do Curso de Enfermagem do UNIPAM, na Rua Major Gote $n^{\circ} 808$, Patos de Minas (MG), no horário de 19:00 as 22:30 ou pelo e-mail: maryrivany@yahoo.com.br. 
Agradecemos a sua colaboração!

$\mathrm{Eu}$, portador (a) do documento de Identidade__ (se já tiver documento), fui informado(a) dos objetivos do presente estudo de maneira clara e detalhada e esclareci minhas dúvidas. Sei que a qualquer momento poderei solicitar novas informações, e o meu responsável poderá modificar a decisão de participar se assim o desejar. Tendo o consentimento do meu responsável já assinado, declaro que concordo em participar desse estudo. Recebi uma cópia deste termo assentimento e me foi dada a oportunidade de ler e esclarecer as minhas dúvidas.

\section{Assinatura do (a) adolescente menor de 18 anos}

Patos de Minas, de de 20

Marilene Rivany Nunes

Doutoranda - $\mathrm{N}^{\mathrm{O}}$ USP 73.620.60

Rua Major Gote $\mathrm{n}^{\mathrm{0}} 808$, Patos de Minas (MG) Telefone: (34) 9103-8038
Profa.Dra. Marta Angélica Iossi Silva $\mathrm{N}^{\mathrm{o}}$ USP: 1.571.591- EERP-USP Av Bandeirantes, 3900 - Campus USP

Telefone: (16) 3602-34-13 


\section{APÊNDICE F}

Figuras dos Mapas de rede social dos 26 adolescentes em LA participantes deste estudo

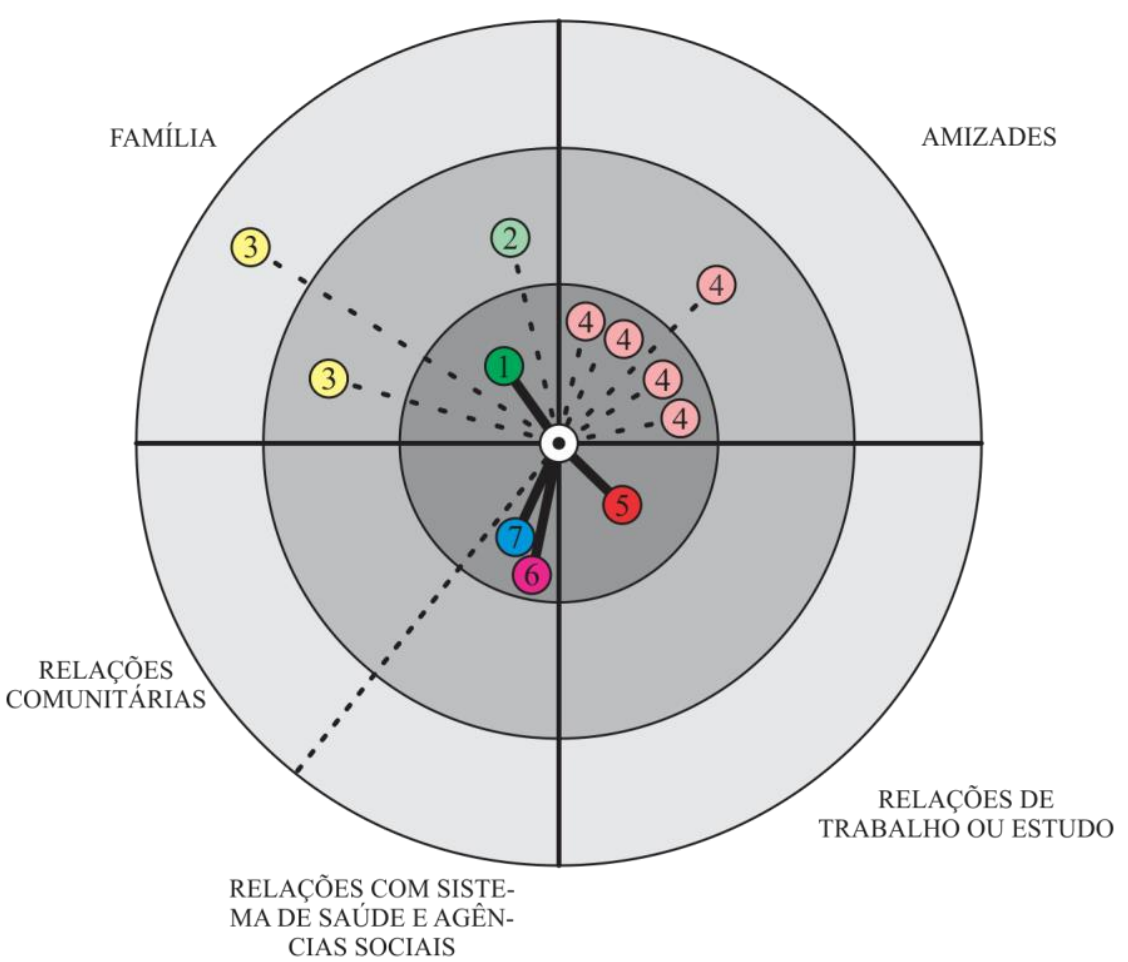

LEGENDA
- Adolescente
Vínculo Significativo
(1) Avô
(2) Mãe
(3) Tia
(4) Amigo(a)
(5) Colega de escola
6) Psicólogo - CREAS
(7) CREAS
. - . Vínculo Fragilizado
Relações íntimas
(família e grupo significativo)
Relações sociais
(com contato pessoal)
Conhecidos
(relações ocasionais distantes)

Figura 3 - Mapa de rede social do adolescente em LA - Amizade, 13 anos 


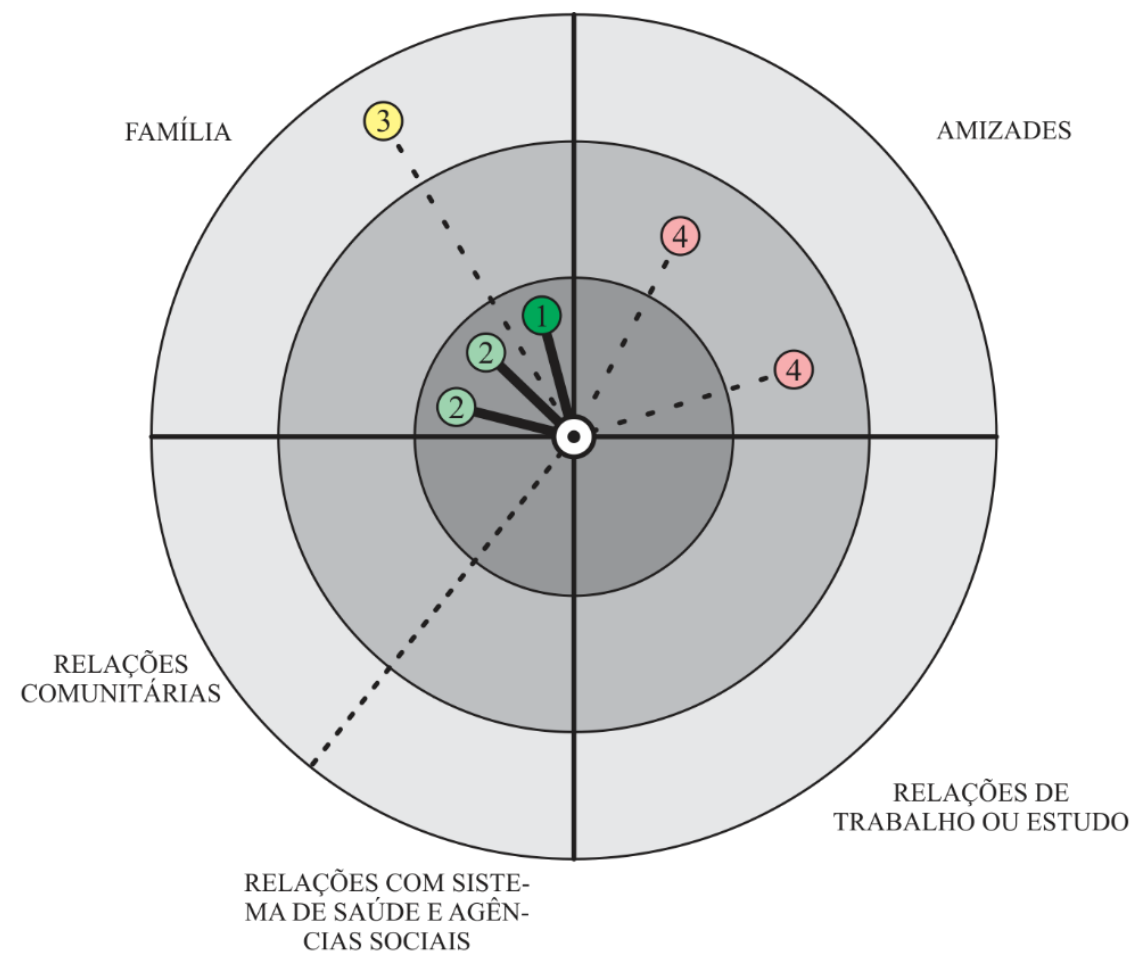

LEGENDA

- Adolescente

(1) Mãe

(2) Irmãs

(3) Pai

(4) Amigo(a)

Vínculo Significativo

. - Vínculo Fragilizado
Relações íntimas

(família e grupo significativo)

Relações sociais

(com contato pessoal)

Conhecidos

(relações ocasionais distantes)

Figura 4 - Mapa de rede social do adolescente em LA - Aventura, 15 anos 


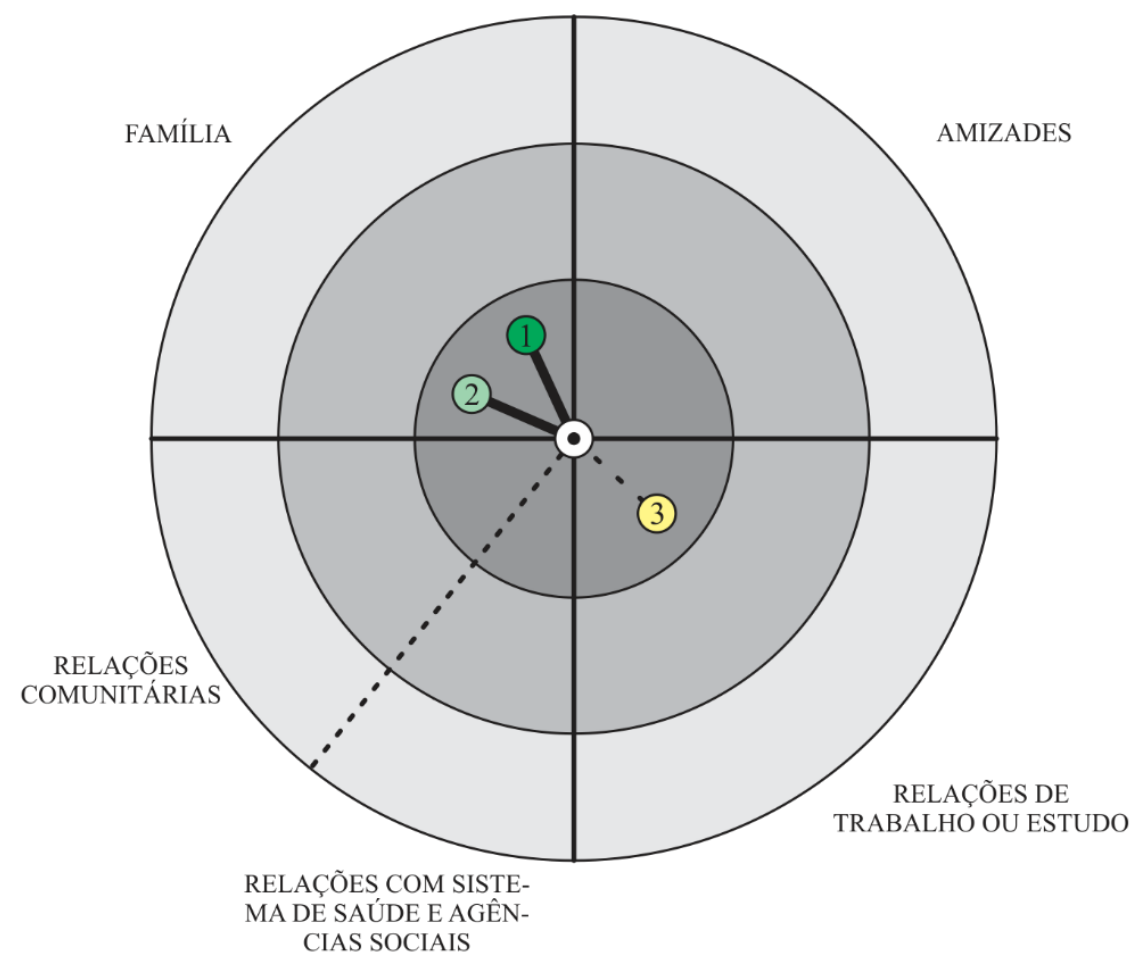

LEGENDA

- Adolescente

(1) Mãe

Relações íntimas

(família e grupo significativo)

(2) Irmã

(3) Patrão

(com contato pessoal)

Vínculo Significativo

Conhecidos

(relações ocasionais distantes)

... Vínculo Fragilizado

Figura 5 - Mapa de rede social do adolescente em LA - Branco, 17 anos 


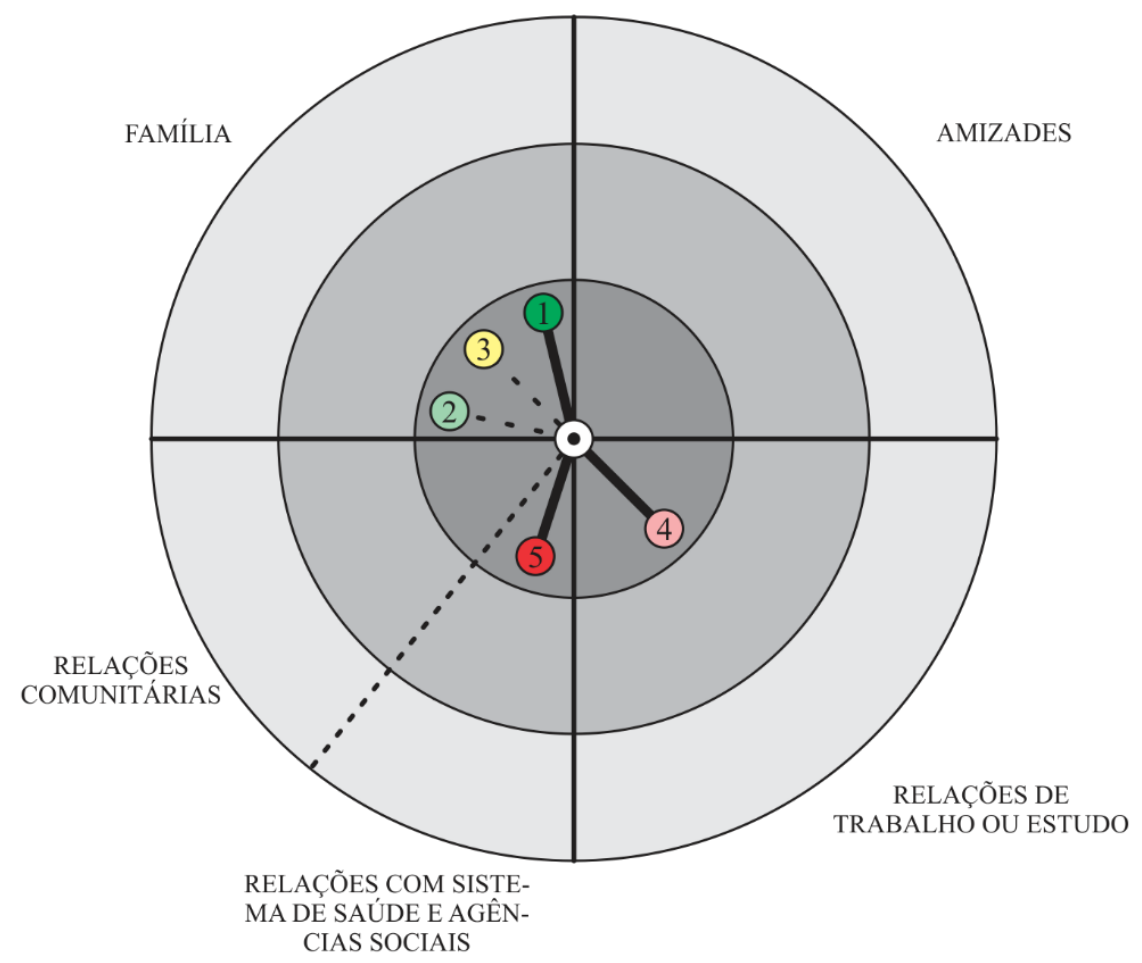

LEGENDA

- Adolescente

(1) Pai

(2) Madrasta

(3) Namorado(a)

(4) Professora de Português

5) Psicólogo - CREAS

Vínculo Significativo

- - Vínculo Fragilizado
Relações íntimas

(família e grupo significativo)

Relações sociais

(com contato pessoal)

Conhecidos

(relações ocasionais distantes)

Figura 6 - Mapa de rede social do adolescente em LA - Branquinha, 16 anos 


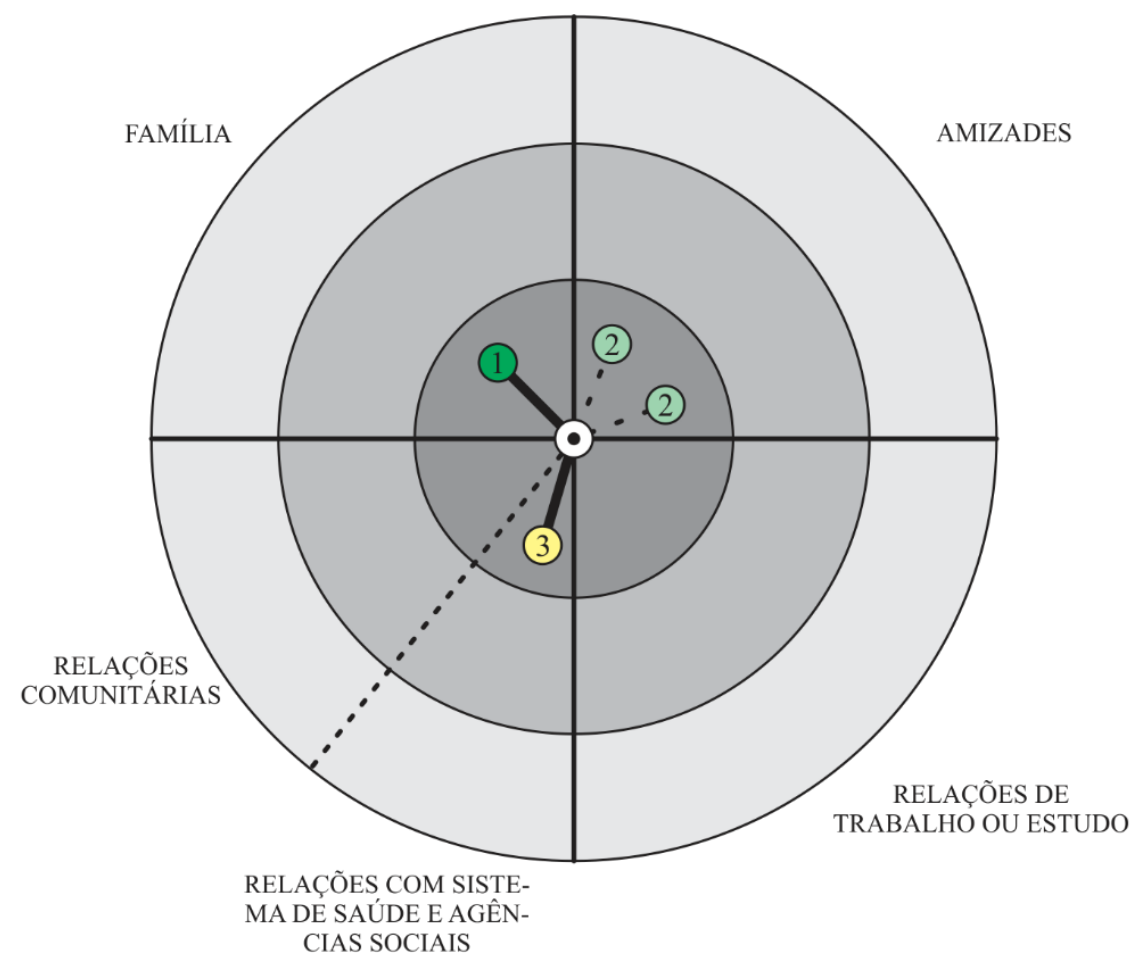

LEGENDA

- Adolescente

(1) Mãe

(2) Amigo(a)

(3) Psicólogo - CREAS

Vínculo Significativo

-. Vínculo Fragilizado
Relações íntimas

(família e grupo significativo)

Relações sociais

(com contato pessoal)

Conhecidos

(relações ocasionais distantes)

Figura 7 - Mapa de rede social do adolescente em LA - Cachaça, 18 anos 


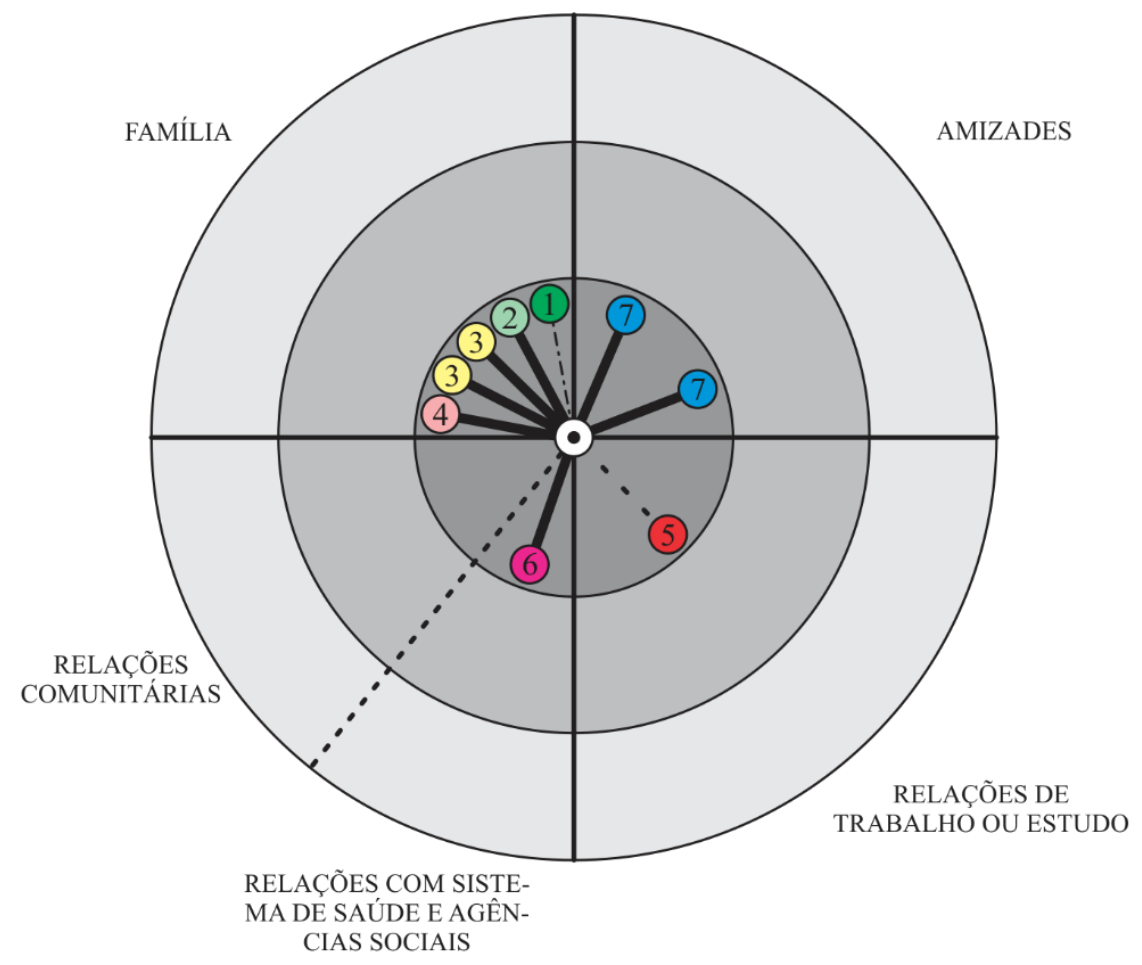

LEGENDA

- Adolescente Vínculo Significativo

(1) Mãe … Vínculo Fragilizado

(2) Pai

(3) Irmãos

(4) Tia

(5) Colega de Escola

Relações íntimas

(família e grupo significativo)

(6) CREAS

(7) Amigo(a)

Relações sociais

(com contato pessoal)

Conhecidos

(relações ocasionais distantes)

Figura 8 - Mapa de rede social do adolescente em LA - Cantora, 16 anos 


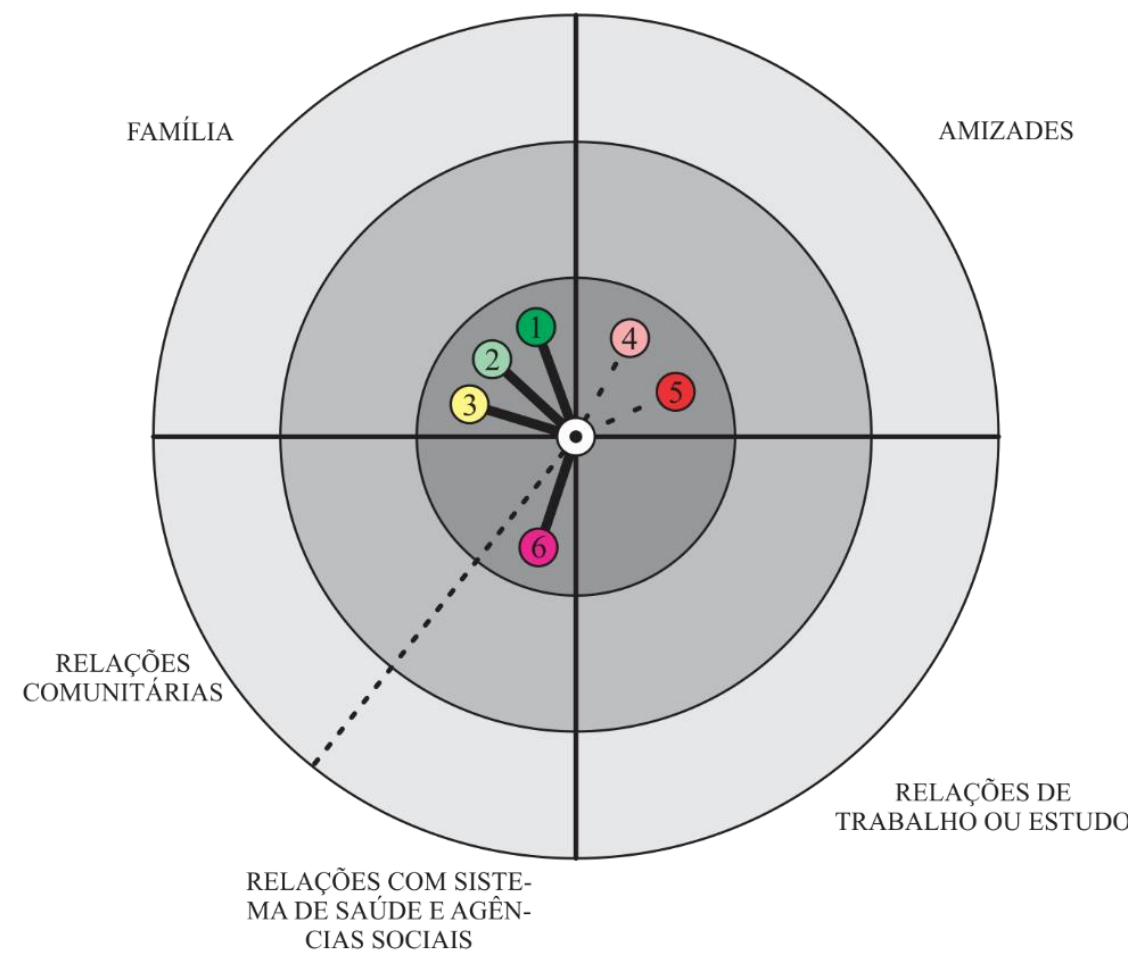

LEGENDA

- Adolescente

Vínculo Significativo

(1) Mãe

(2) $\mathrm{Pai}$

(3) Tio

(4) Namorado

(5) Amigo(a)

(6) Psicólogo - CREAS

- - Vínculo Fragilizado

Relações íntimas

(família e grupo significativo)

Relações sociais

(com contato pessoal)

Conhecidos

(relações ocasionais distantes)

Figura 9 - Mapa de rede social do adolescente em LA - Companheiro, 17 anos 


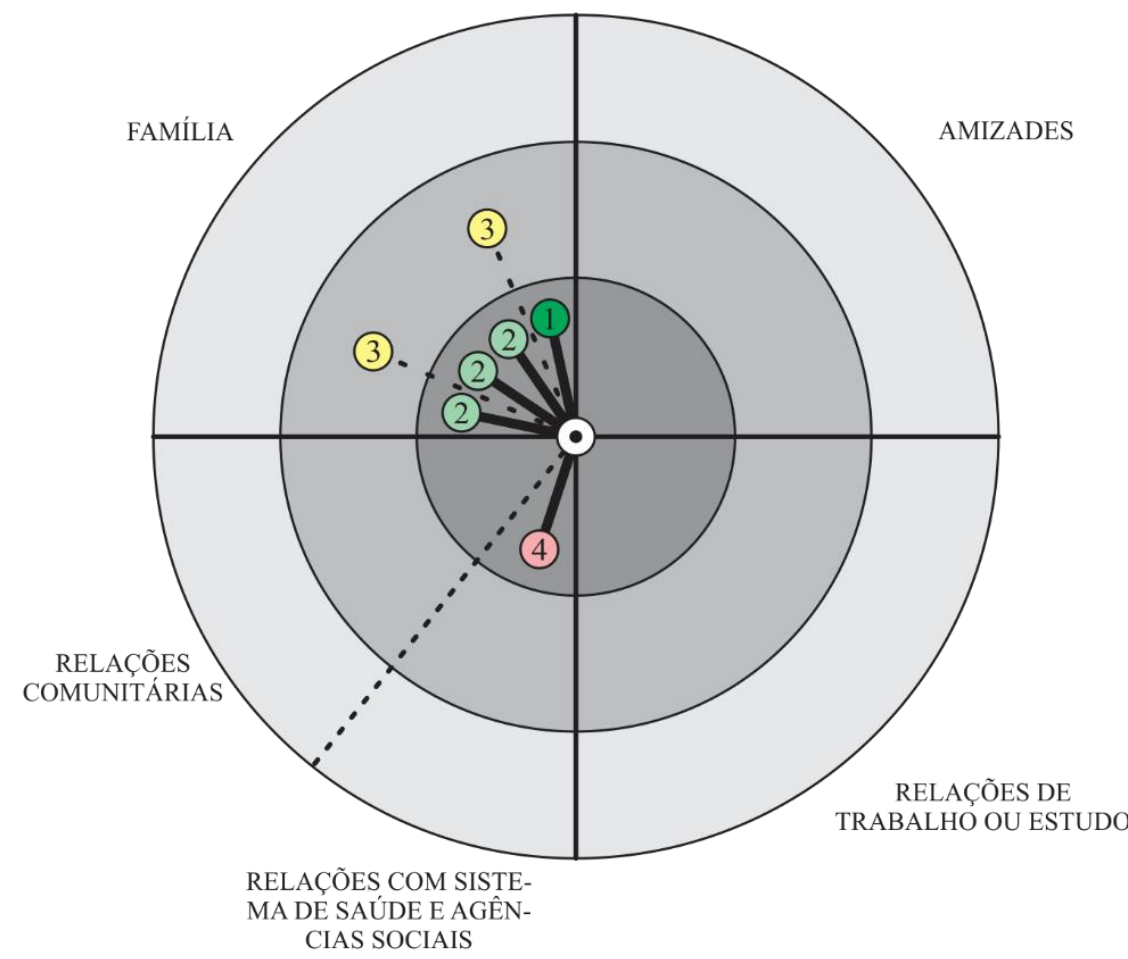

LEGENDA

- Adolescente

Vínculo Significativo

(1) Mãe

(2) Irmãs

(3) Primos

(4) Psicólogo - CREAS

(família e grupo significativo)

Relações sociais

(com contato pessoal)

Conhecidos

(relações ocasionais distantes)

Figura 10 - Mapa de rede social do adolescente em LA - Capoeira, 14 anos 


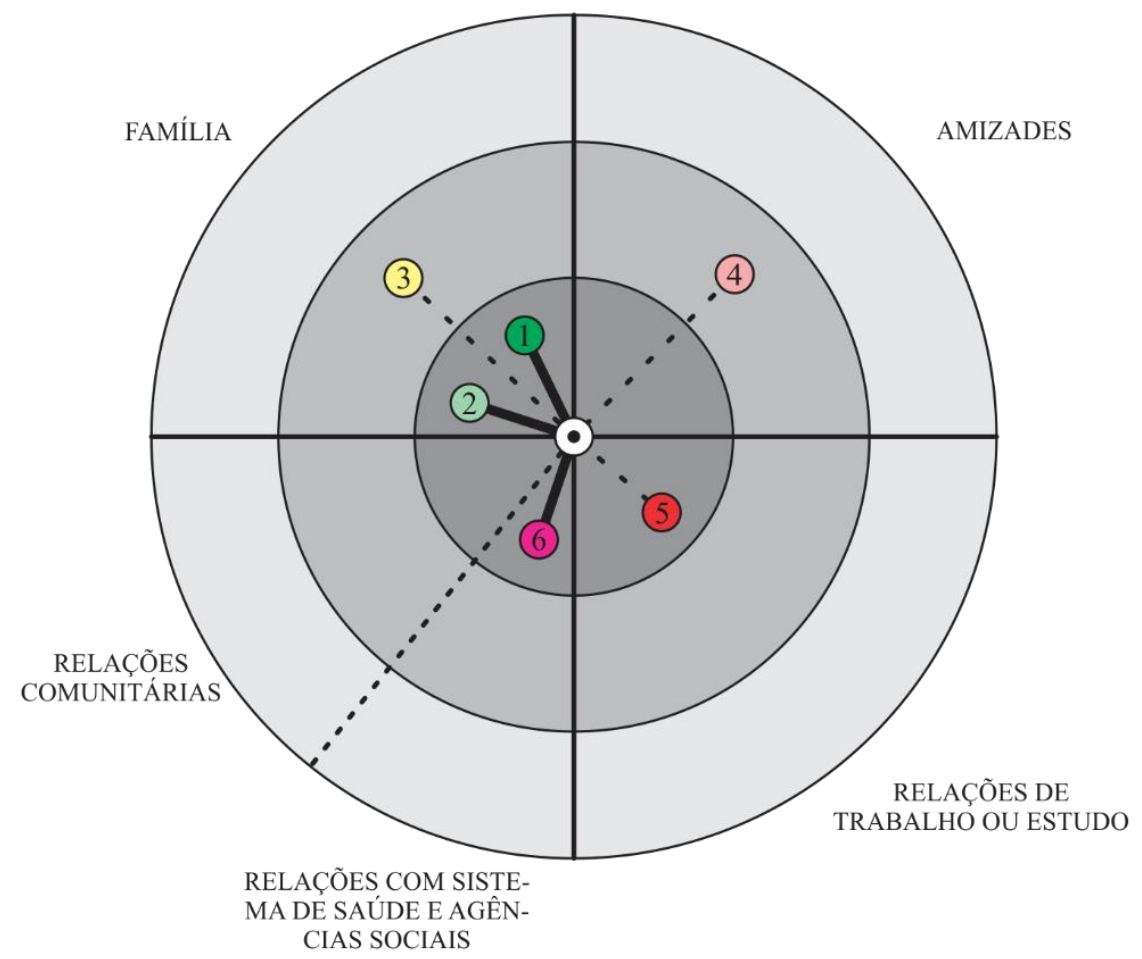

LEGENDA

- Adolescente

Vínculo Significativo

(1) Mãe

(2) Avó

(3) Pai

(4) Namorado(a)

(5) Professora

(6) Psicólogo - CREAS

- - Vínculo Fragilizado

Relações íntimas

(família e grupo significativo)

Relações sociais

(com contato pessoal)

Conhecidos

(relações ocasionais distantes)

Figura 11 - Mapa de rede social do adolescente em LA - Dança, 14 anos 


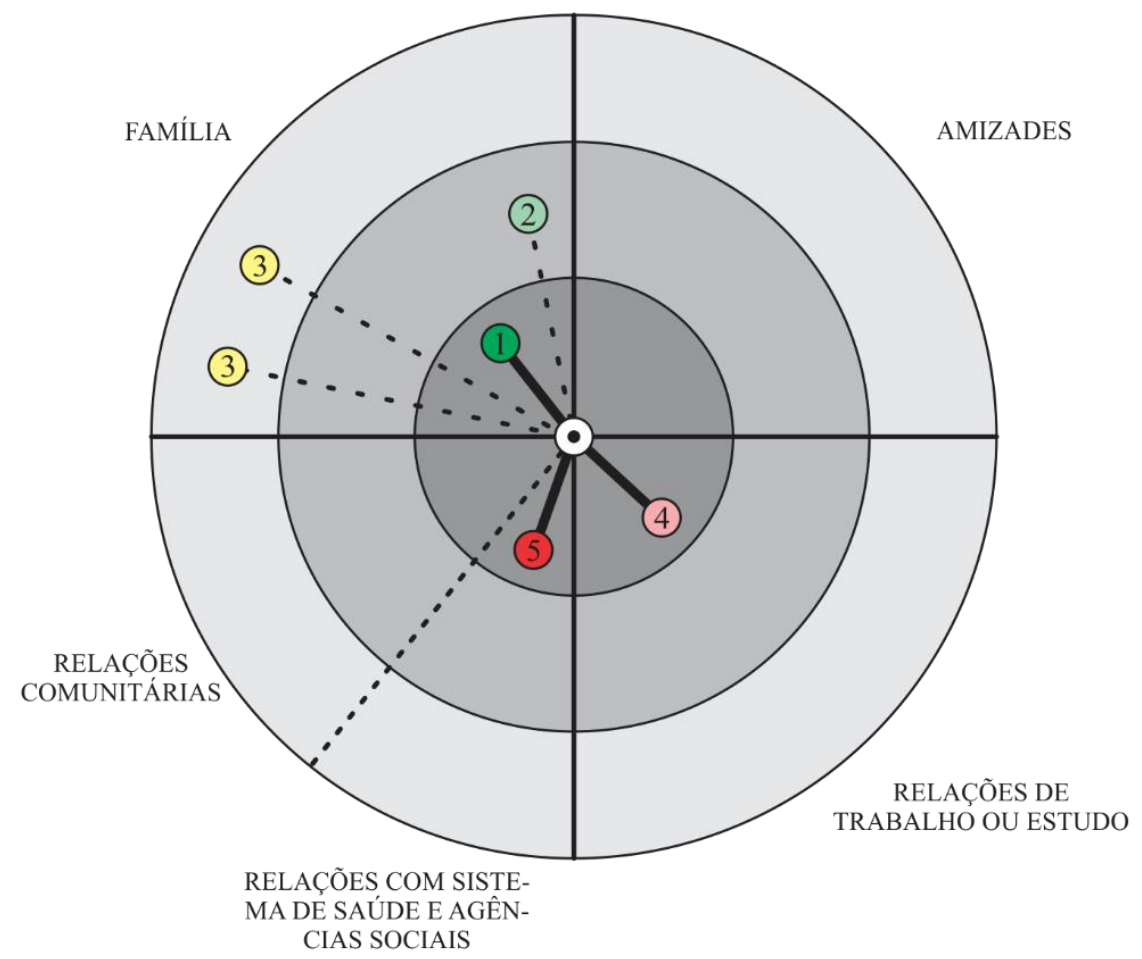

LEGENDA

- Adolescente

Vínculo Significativo

(1) Mãe

(2) Pai

(3) Irmãos

(4) Namorado(a)

(5) CREAS

- - Vínculo Fragilizado

Relações íntimas

(família e grupo significativo)

Relações sociais

(com contato pessoal)

Conhecidos

(relações ocasionais distantes)

Figura 12 - Mapa de rede social do adolescente em LA - Esporte, 16 anos 


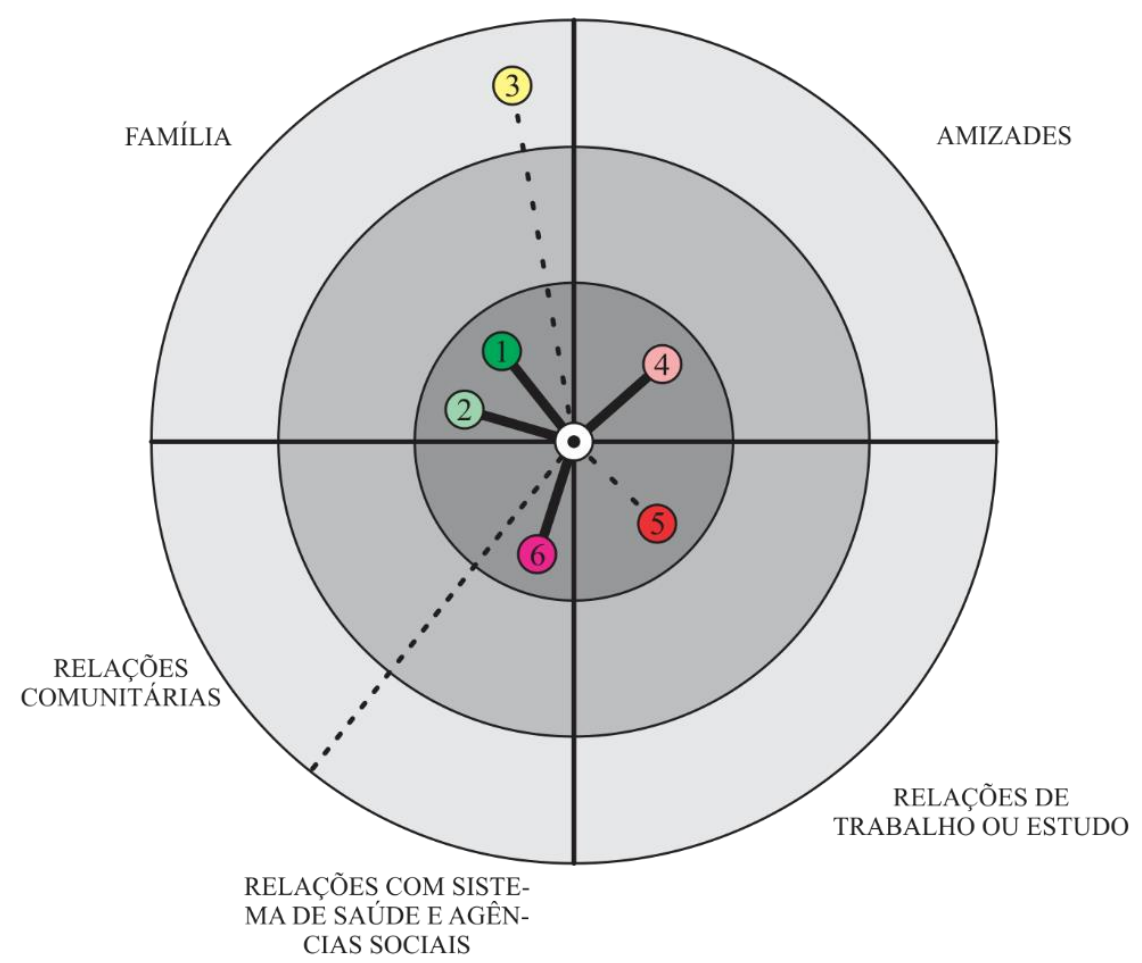

LEGENDA

- Adolescente

Vínculo Significativo

(1) Mãe

(2) Irmã

(3) Pai

(4) Deus

(5) Professora

6) CREAS

- - Vínculo Fragilizado

Relações íntimas

(família e grupo significativo)

Relações sociais

(com contato pessoal)

Conhecidos

(relações ocasionais distantes)

Figura 13 - Mapa de rede social do adolescente em LA - Festa, 17 anos 


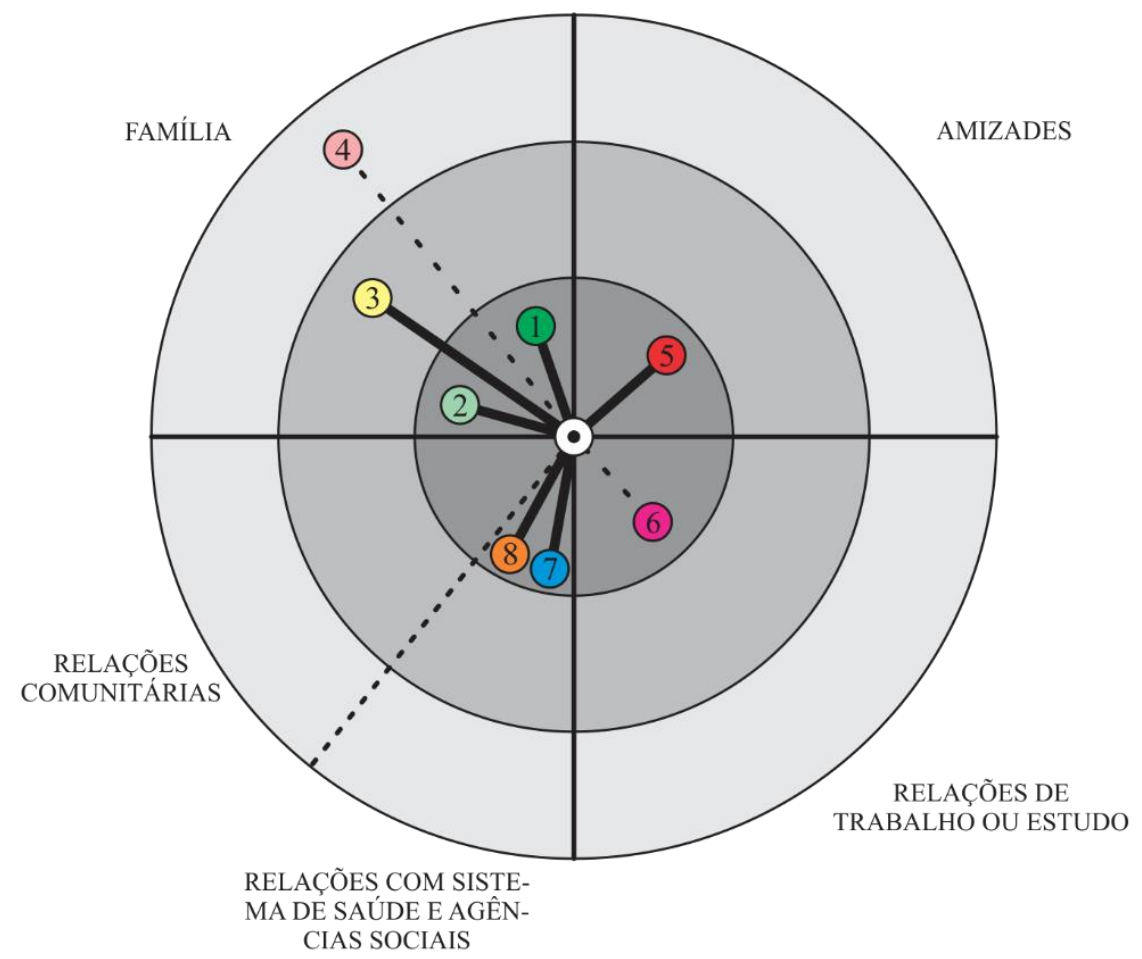

LEGENDA

- Adolescente

Vínculo Significativo

(1) Mãe

(2) $\mathrm{Pai}$

(3) Primo

(4) Tio

(5) Amigo(a)

(6) Colega de escola

(7) CREAS

(8) Psicólogo - CREAS

-.. Vínculo Fragilizado

Relações íntimas

(família e grupo significativo)

Relações sociais

(com contato pessoal)

Conhecidos

(relações ocasionais distantes)

Figura 14 - Mapa de rede social do adolescente em LA - Futebol, 15 anos 


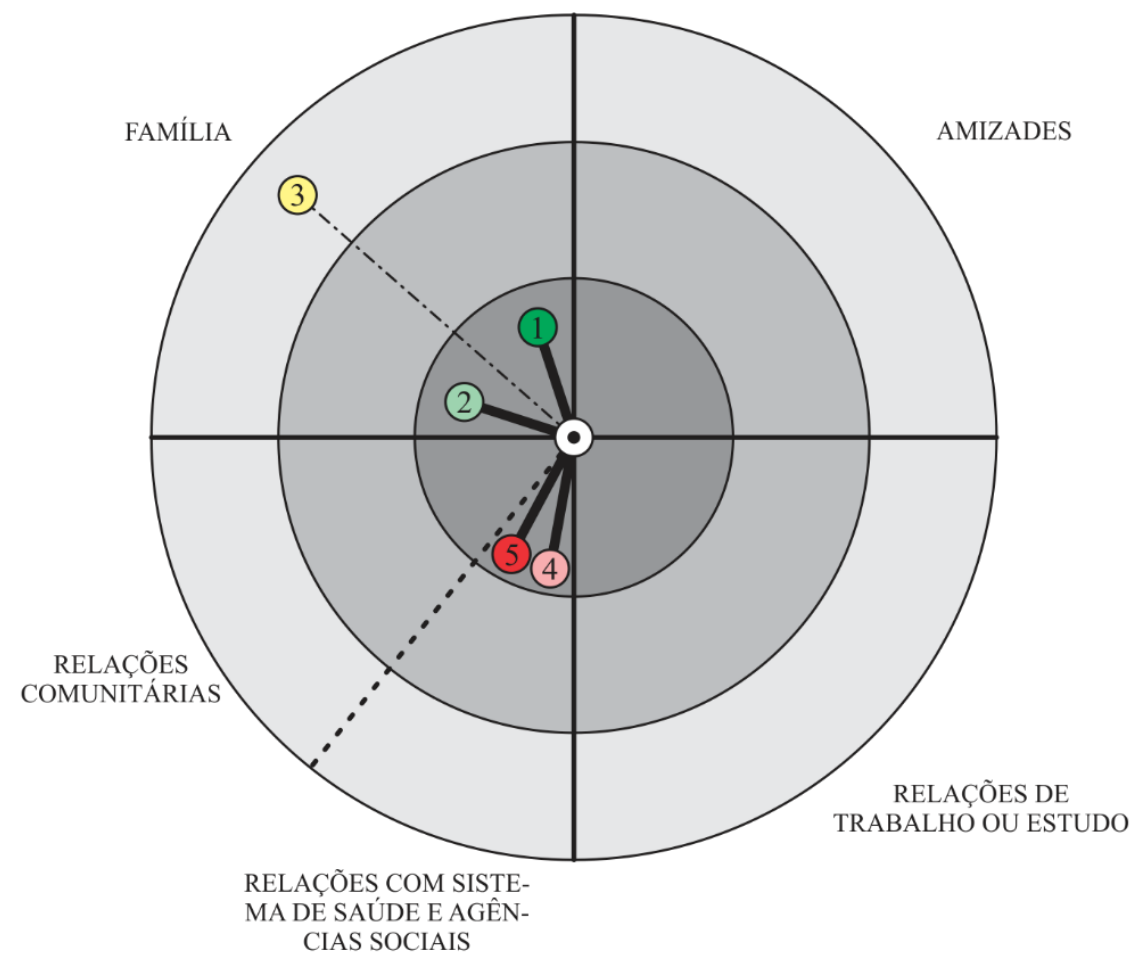

LEGENDA

- Adolescente

Vínculo Significativo

(1) Mãe

(2) Tia

(3) Pai

(4) CREAS

(5) Psicólogo - CREAS

Vínculo Rompido

Relações íntimas

(família e grupo significativo)

Relações sociais

(com contato pessoal)

Conhecidos

(relações ocasionais distantes)

Figura 15 - Mapa de rede social do adolescente em LA - Igreja, 18 anos 


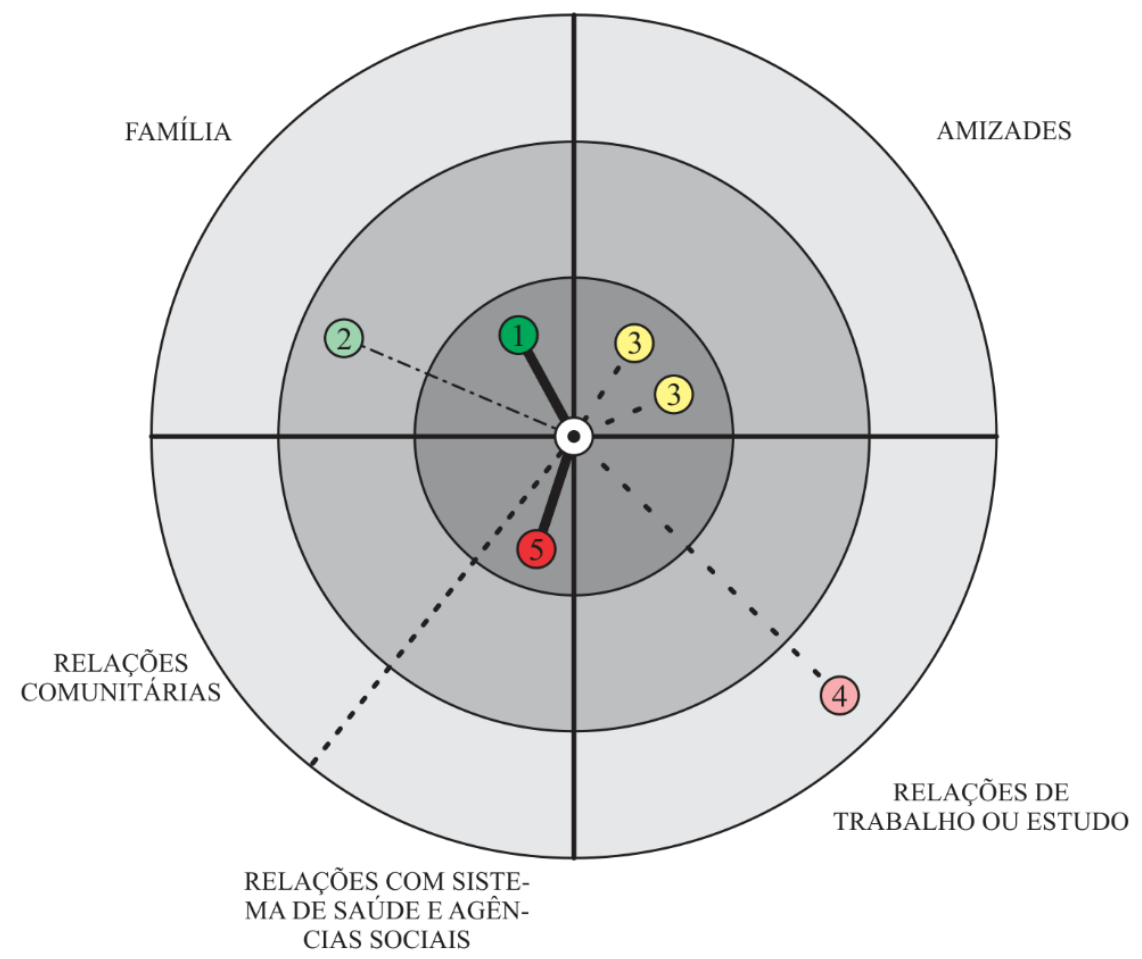

LEGENDA

- Adolescente

Vínculo Significativo

(1) Mãe

(2) Pai

(3) Amigo(a)

- - Vínculo Fragilizado

(4) Professora

Assistente Social - CREAS

Vínculo Rompido

Relações íntimas

(família e grupo significativo)

Relações sociais

(com contato pessoal)

Conhecidos

(relações ocasionais distantes)

Figura 16 - Mapa de rede social do adolescente em LA - Lagoa, 18 anos 


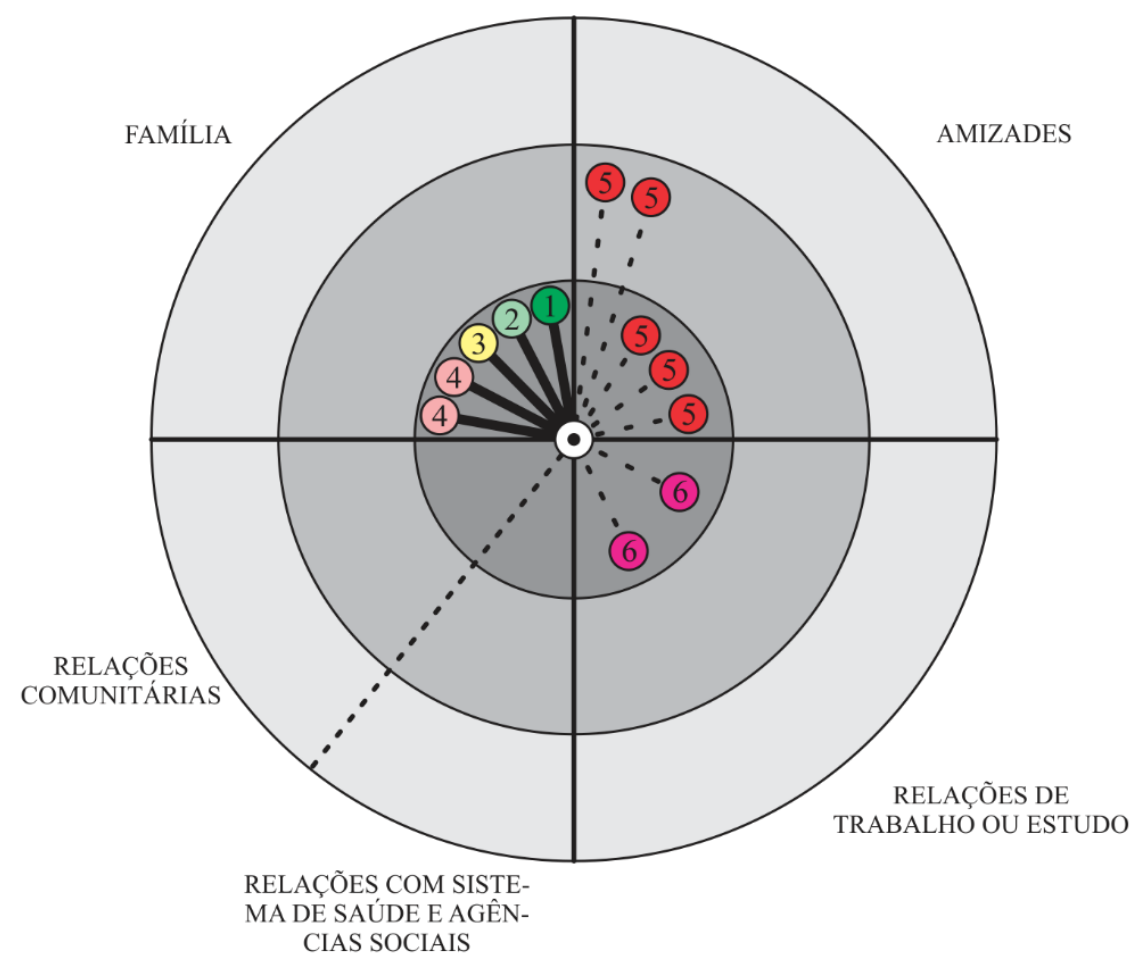

LEGENDA

- Adolescente

Vínculo Significativo

(1) Mãe

(2) Pai

(3) Avó

(4) $\mathrm{Tia}(\mathrm{o})$

(5) Amigo(a)

(6) Colegas de Trabalho

- - Vínculo Fragilizado

Relações íntimas

(família e grupo significativo)

Relações sociais

(com contato pessoal)

Conhecidos

(relações ocasionais distantes)

Figura 17 - Mapa de rede social do adolescente em LA - Lutador, 18 anos 


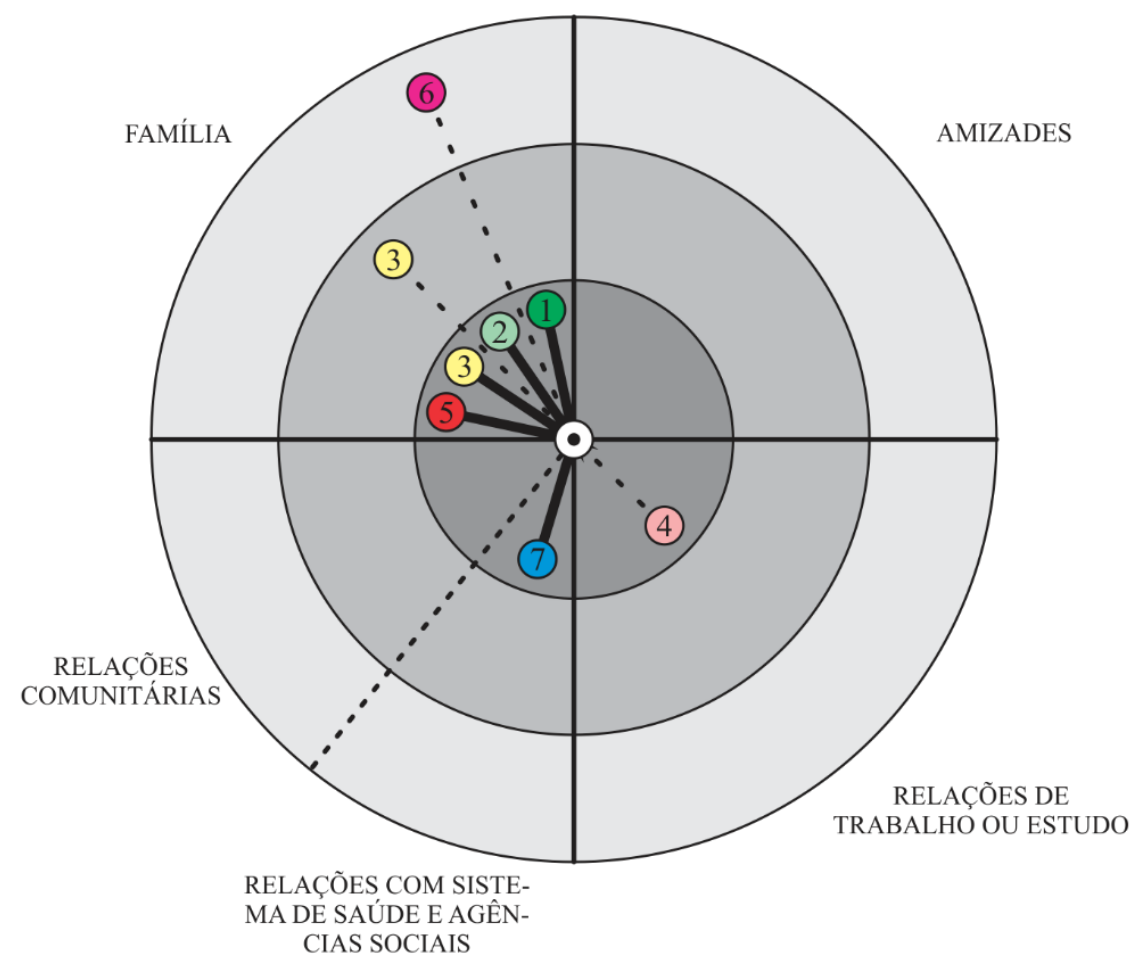

LEGENDA

- Adolescente Vínculo Significativo

(1) Mãe $\quad$. . Vínculo Fragilizado

(2) Pai

(3) Irmã

(4) Namorado(a)

(5) Avó

(6) Tia

(7) CREAS

Relações íntimas

(família e grupo significativo)

Relações sociais

(com contato pessoal)

Conhecidos

(relações ocasionais distantes)

Figura 18 - Mapa de rede social do adolescente em LA - Moda, 18 anos 


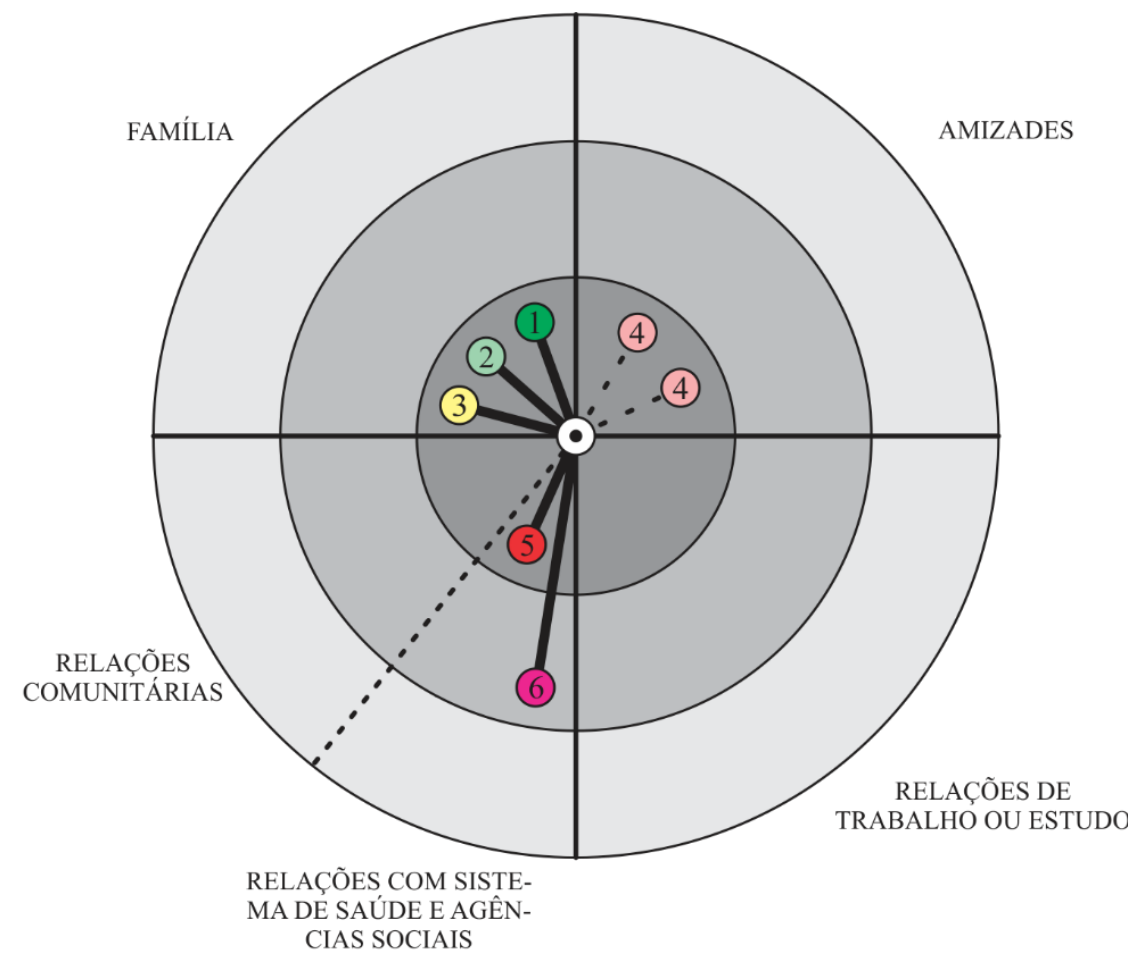

LEGENDA

- Adolescente

—. . Vínculo Significativo

(1) Mãe

(2) Padrasto

(3) Avó

(4) Amigo(a)

(5) CREAS

(6) Psicólogo - CREAS

Relações íntimas

(família e grupo significativo)

Relações sociais

(com contato pessoal)

Conhecidos

(relações ocasionais distantes)

Figura 19 - Mapa de rede social do adolescente em LA - Moreninha, 15 anos 


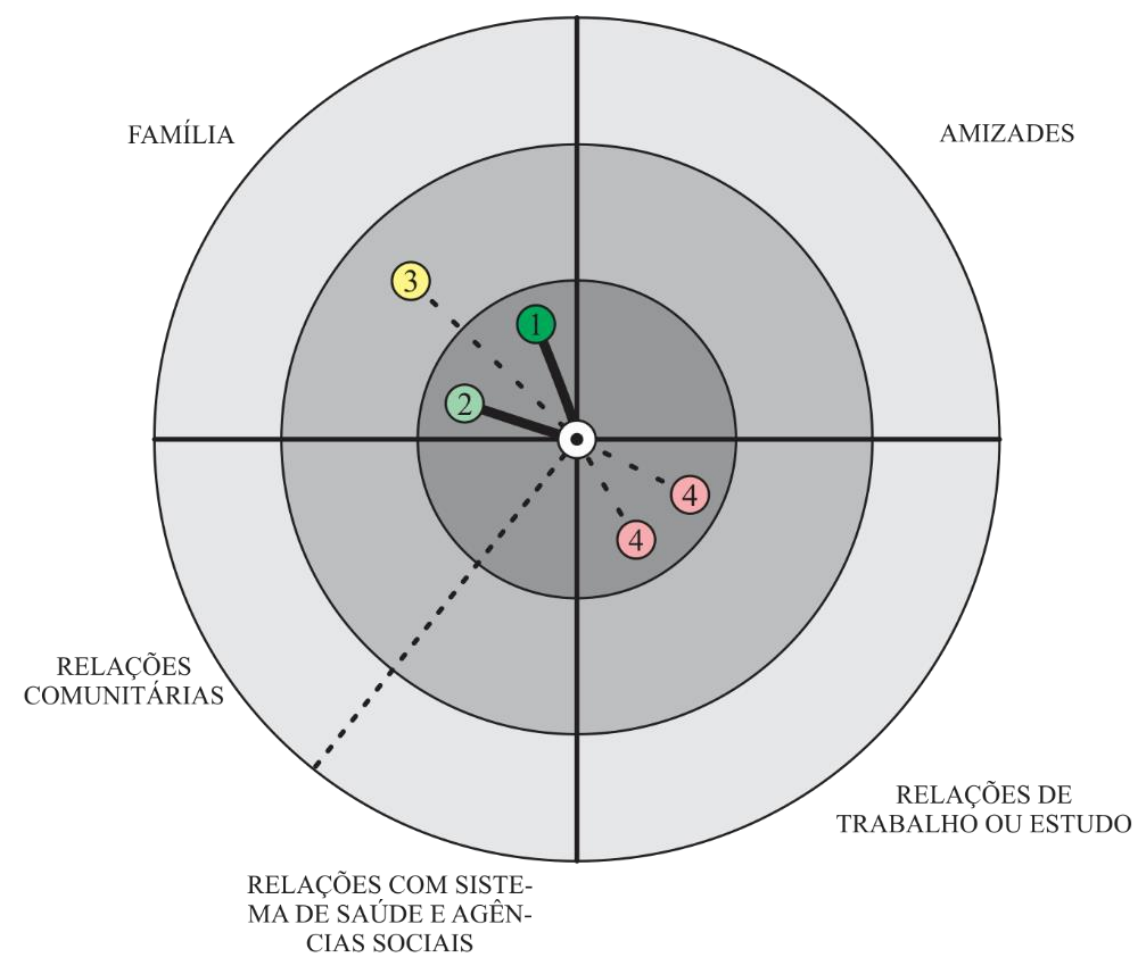

LEGENDA

- Adolescente

(1) Mãe

(2) Irmã

(3) Pai

(4) Colega de escola

Vínculo Significativo
Relações íntimas

(família e grupo significativo)

Relações sociais (com contato pessoal)

Conhecidos

(relações ocasionais distantes)

. - Vínculo Fragilizado

Figura 20 - Mapa de rede social do adolescente em LA - Moreno, 14 anos 


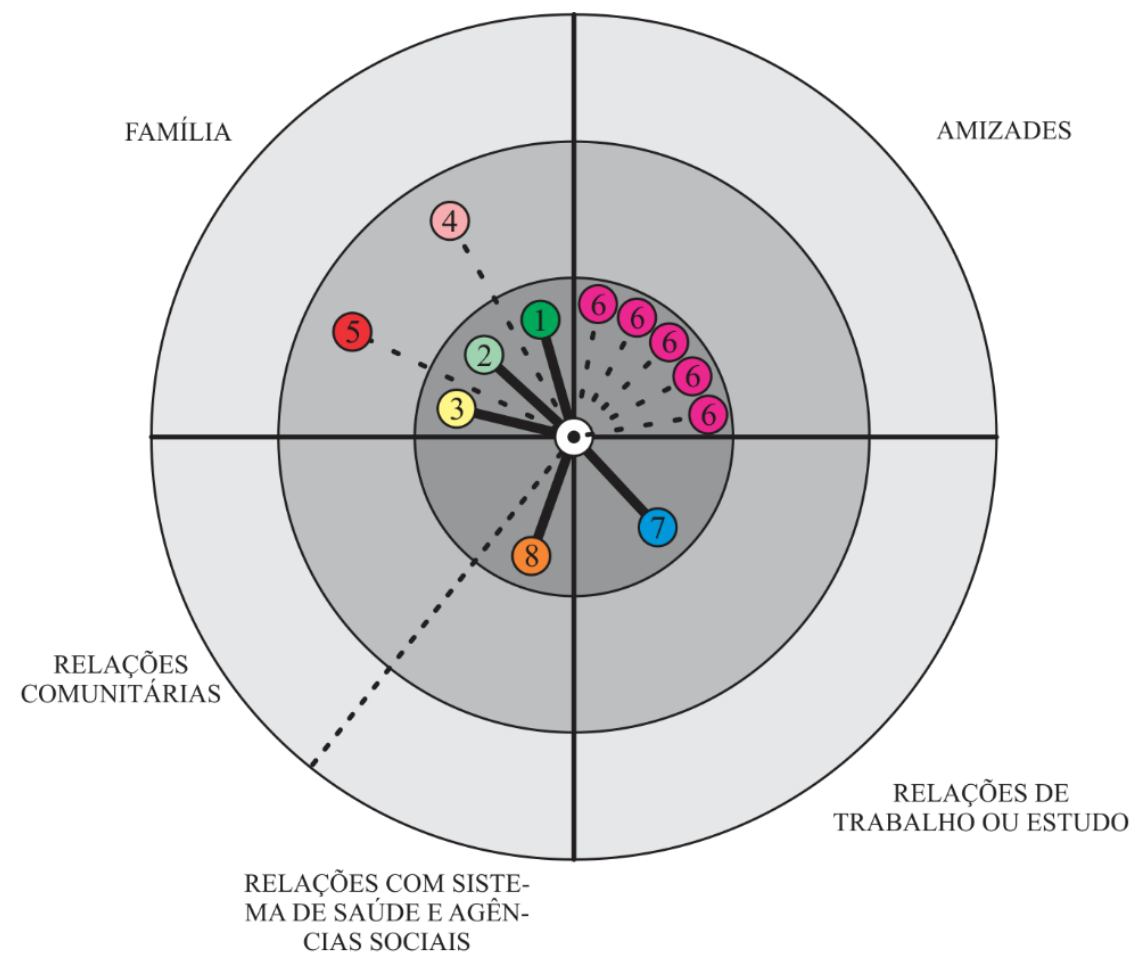

LEGENDA
- Adolescente
Vínculo Significativo
(1) Mãe
(2) Pai
(3) Irmã
(4) Tio
(5) Primos
(6) Amigo(a)
(7) Patrão
(8) CREAS
- - Vínculo Fragilizado
Relações íntimas
(família e grupo significativo)
Relações sociais
(com contato pessoal)
Conhecidos
(relações ocasionais distantes)

Figura 21 - Mapa de rede social do adolescente em LA - Motorista, 17 anos 


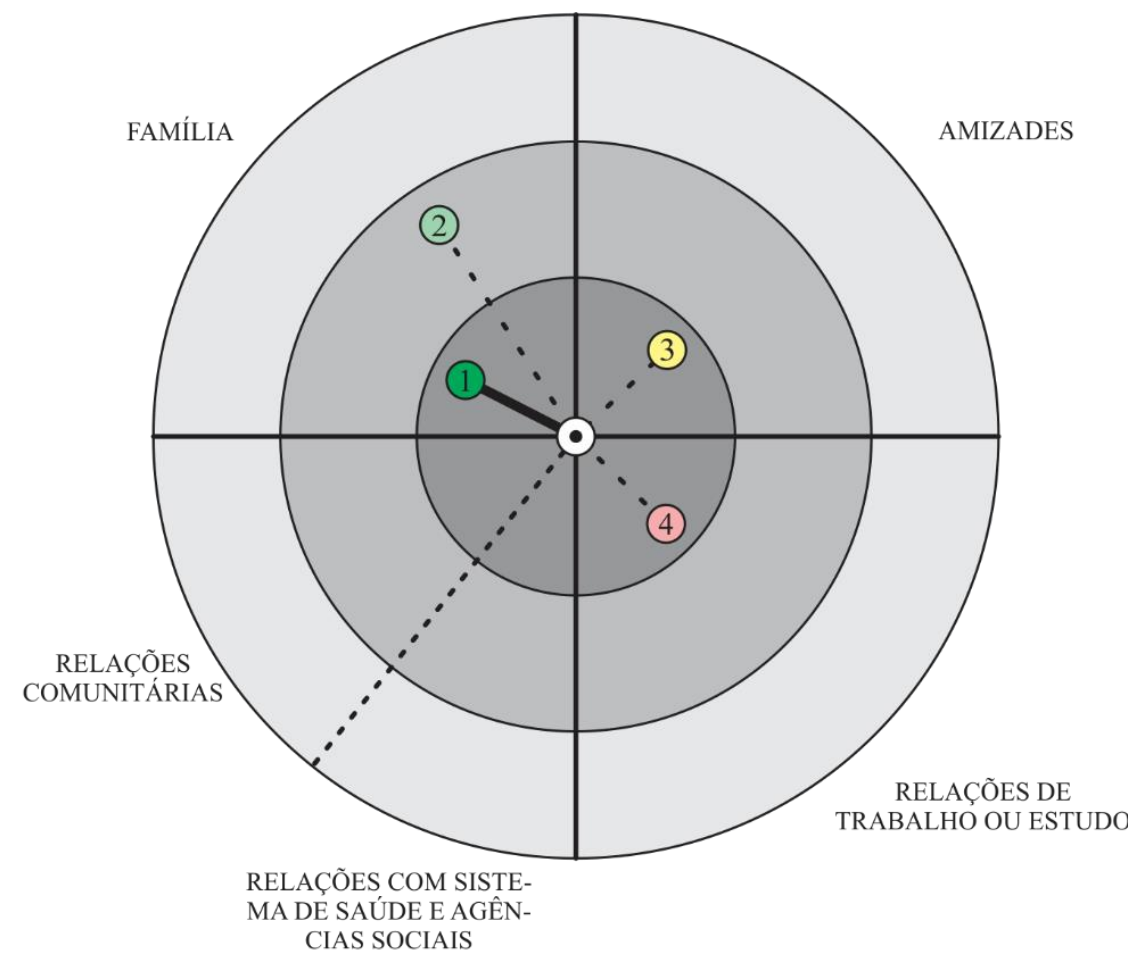

LEGENDA
- Adolescente
(1) Mãe
(2) Irmã
(3) Amigo(a)
(4) Patrão

Relações íntimas

(família e grupo significativo)

Relações sociais

(com contato pessoal)

Conhecidos

(relações ocasionais distantes)

Vínculo Significativo

- - Vínculo Fragilizado

Figura 22 - Mapa de rede social do adolescente em LA - Namorador, 17 anos 


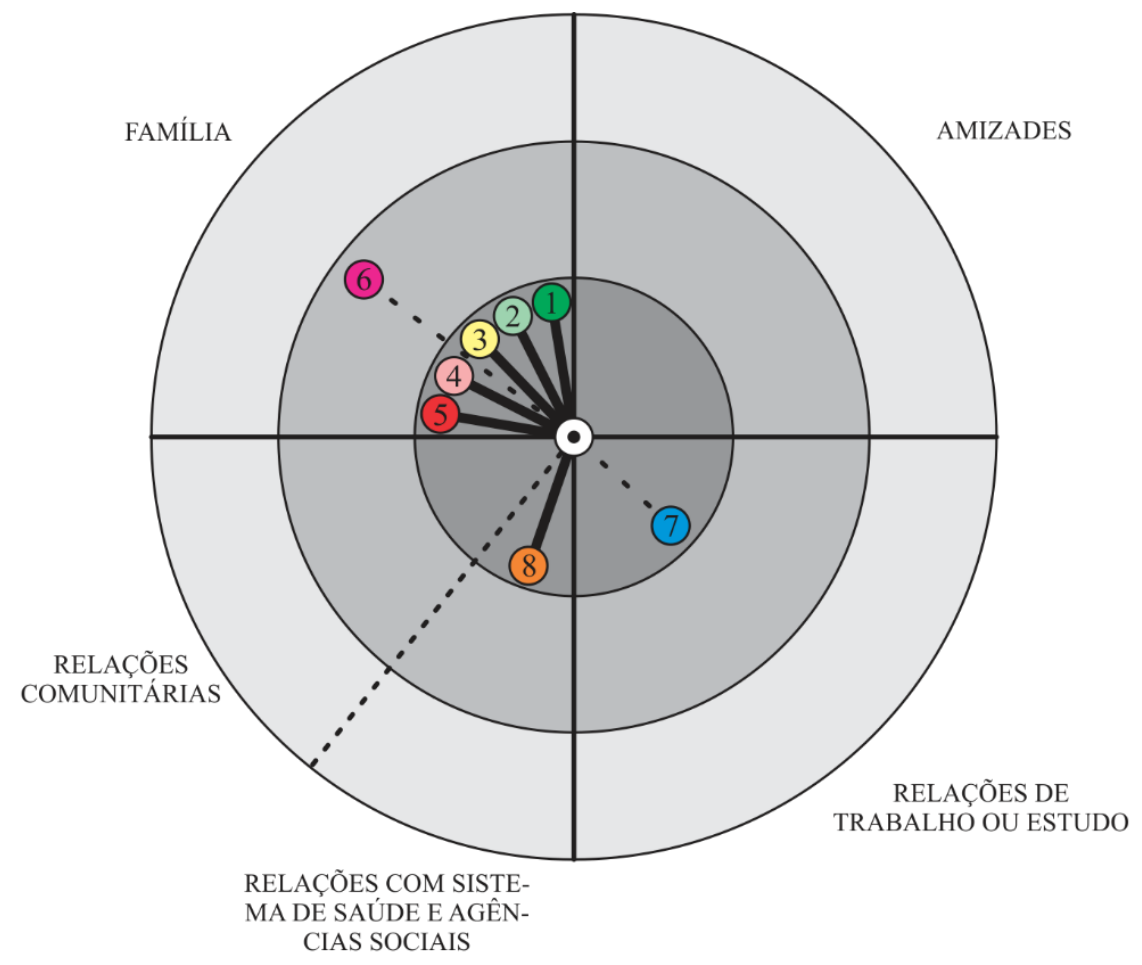

\section{LEGENDA}

- Adolescente

(1) Mãe

(2) Pai

(3) Avó

(4) Irmã

(5) Madrinha

(6) Tio

(7) Professora

(8) Psicólogo - CREAS

\section{Vínculo Significativo}

-.. Vínculo Fragilizado

Relações íntimas (família e grupo significativo)

Relações sociais (com contato pessoal)

Conhecidos

(relações ocasionais distantes)

Figura 23 - Mapa de rede social do adolescente em LA - Prestativo, 15 anos 


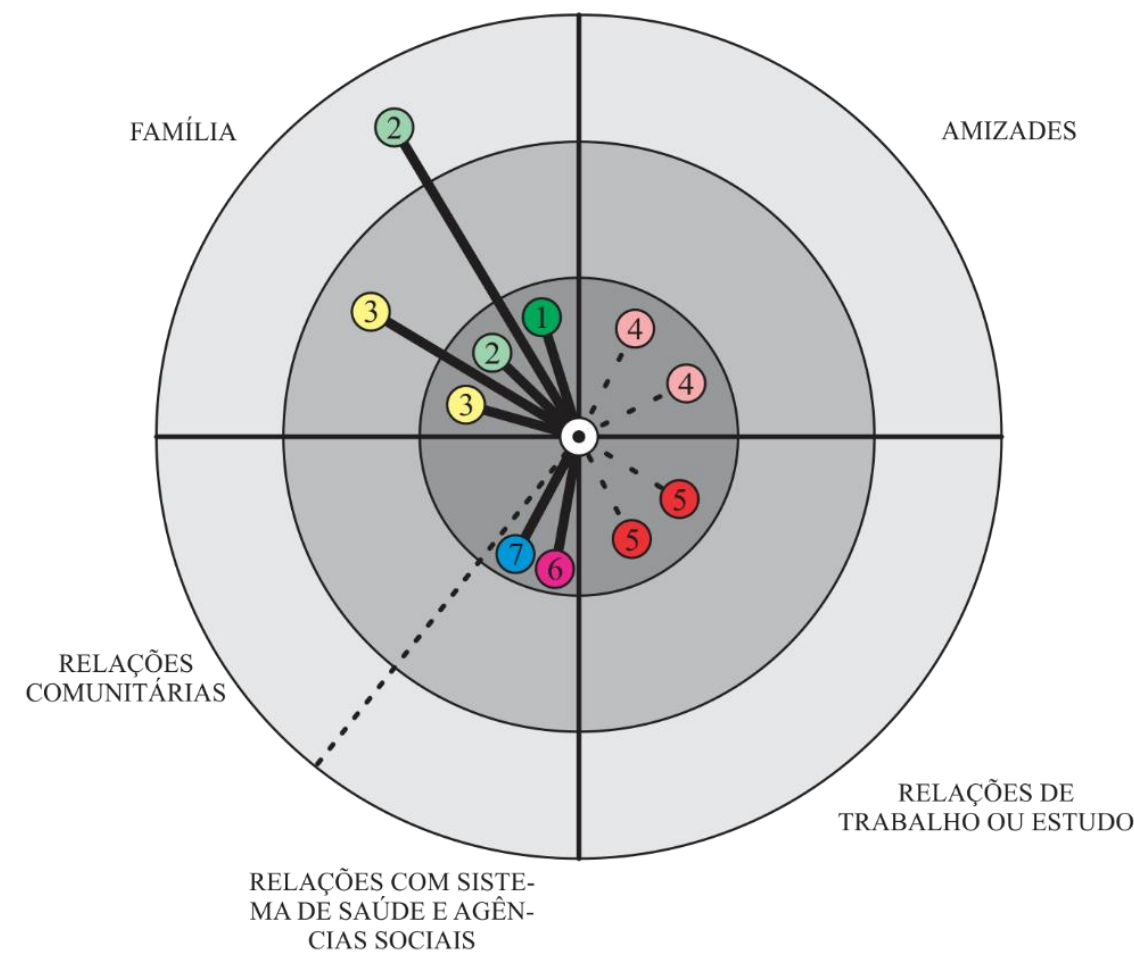

LEGENDA

- Adolescente

Vínculo Significativo

(1) Mãe

(2) Irmã

(3) Primo(a)

-.. Vínculo Fragilizado

(4) Amigo(a)

(5) Colegas de escola

(6) Psicólogo - CREAS

(7) CREAS

Relações íntimas

(família e grupo significativo)

Relações sociais

(com contato pessoal)

Conhecidos

(relações ocasionais distantes)

Figura 24 - Mapa de rede social do adolescente em LA - Piercing, 17 anos 


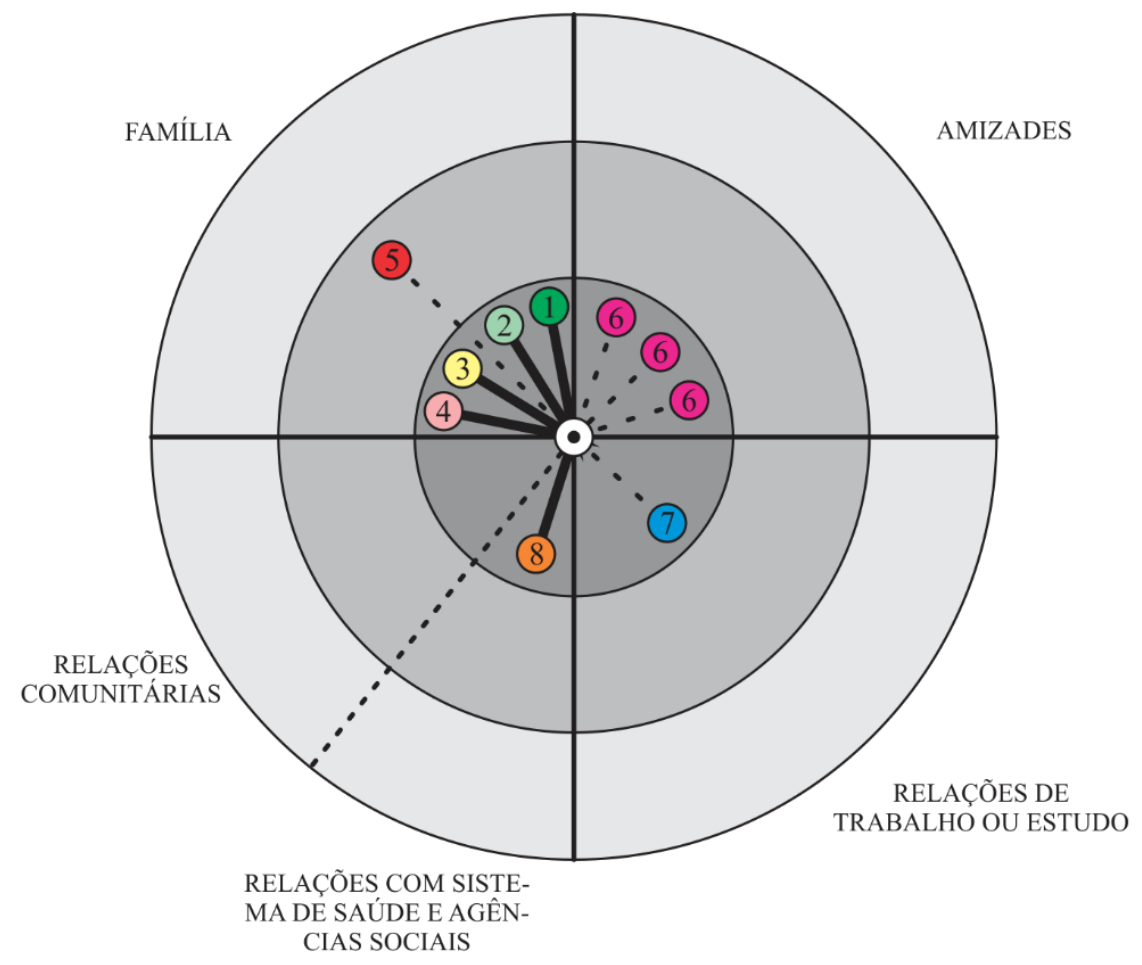

\section{LEGENDA}

- Adolescente

(1) Mãe

(2) Avó

(3) Tia

(4) Namorado(a)

(5) Padrasto

(6) Amigo(a)

(7) Colega de escola

(8) CREAS

\section{Vínculo Significativo}

- - Vínculo Fragilizado

Relações íntimas (família e grupo significativo)

Relações sociais (com contato pessoal)

Conhecidos

(relações ocasionais distantes)

Figura 25 - Mapa de rede social do adolescente em LA - Tean Sagon, 17 anos 


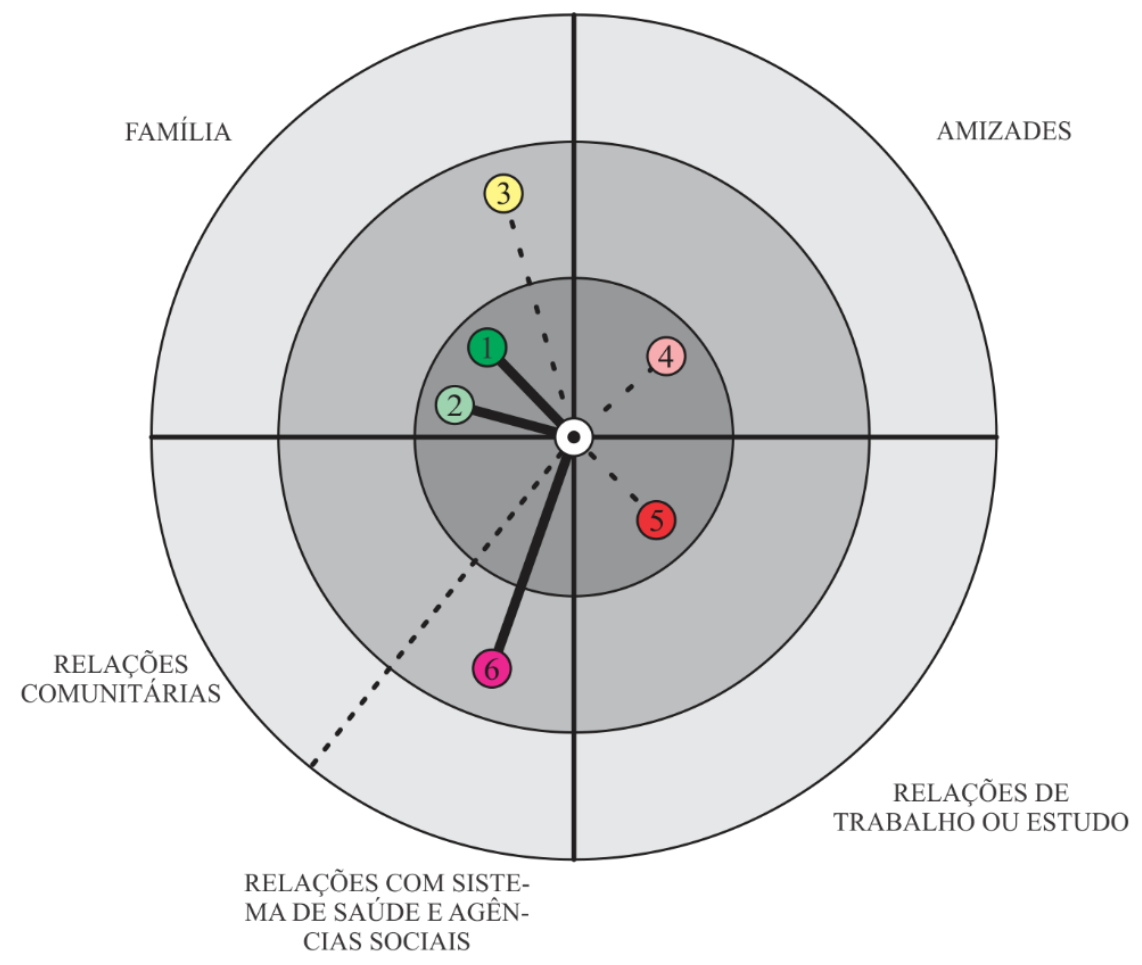

LEGENDA

- Adolescente

Vínculo Significativo

(1) Mãe

(2) Irmã

(3) Pai

- Vínculo Fragilizado

(4) Amigo(a)

(5) Colega de escola

(6) Psicólogo - CREAS

Relações íntimas (família e grupo significativo)

Relações sociais (com contato pessoal)

Conhecidos (relações ocasionais distantes)

Figura 26 - Mapa de rede social do adolescente em LA - Tímido, 16 anos 


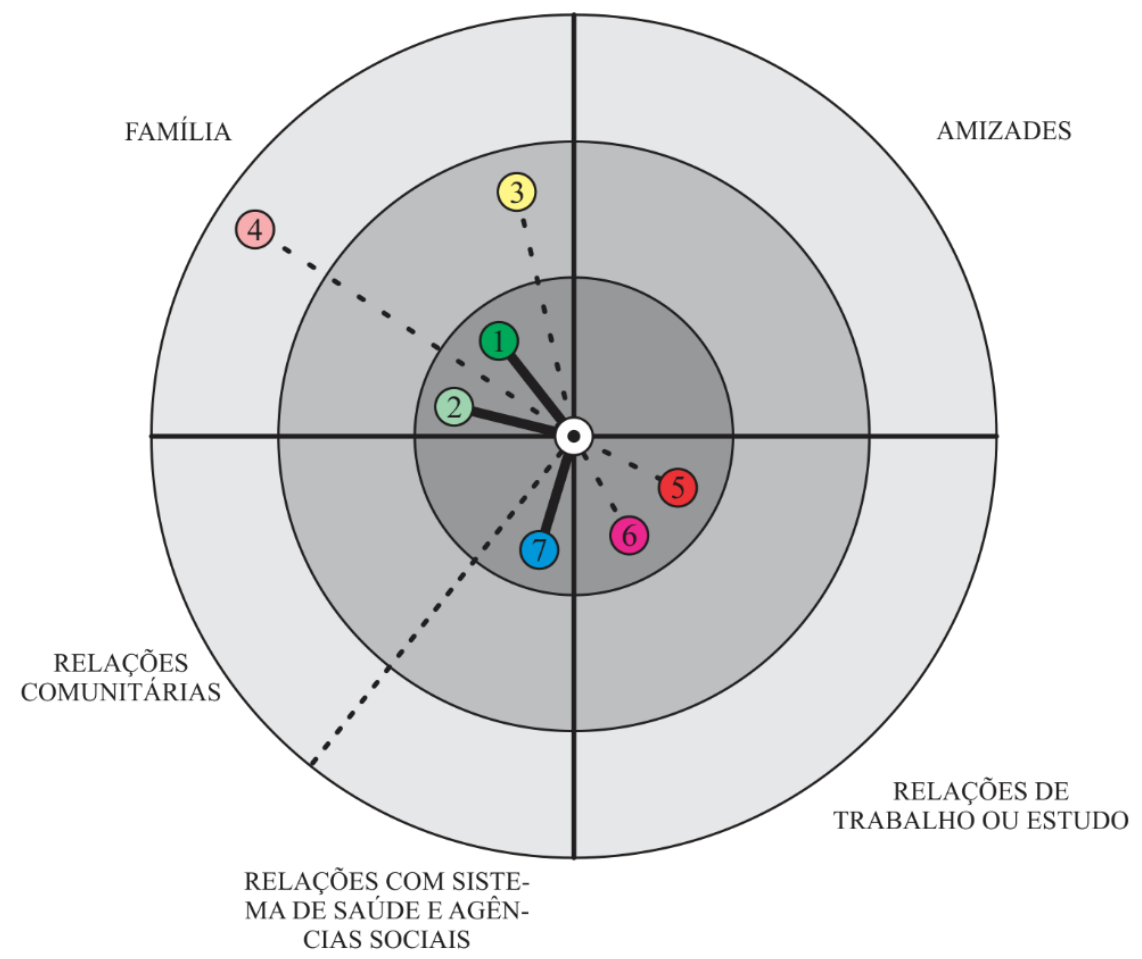

LEGENDA

- Adolescente

Vínculo Significativo

(1) Pai

(2) Namorada

(3) Mãe

-. Vínculo Fragilizado

(4) Irmã

(5) Primo

(6) Colega de Trabalho

(7) Professor de Violão - CREAS

Relações íntimas

(família e grupo significativo)

Relações sociais

(com contato pessoal)

Conhecidos

(relações ocasionais distantes)

Figura 27 - Mapa de rede social do adolescente em LA - Violão, 18 anos 


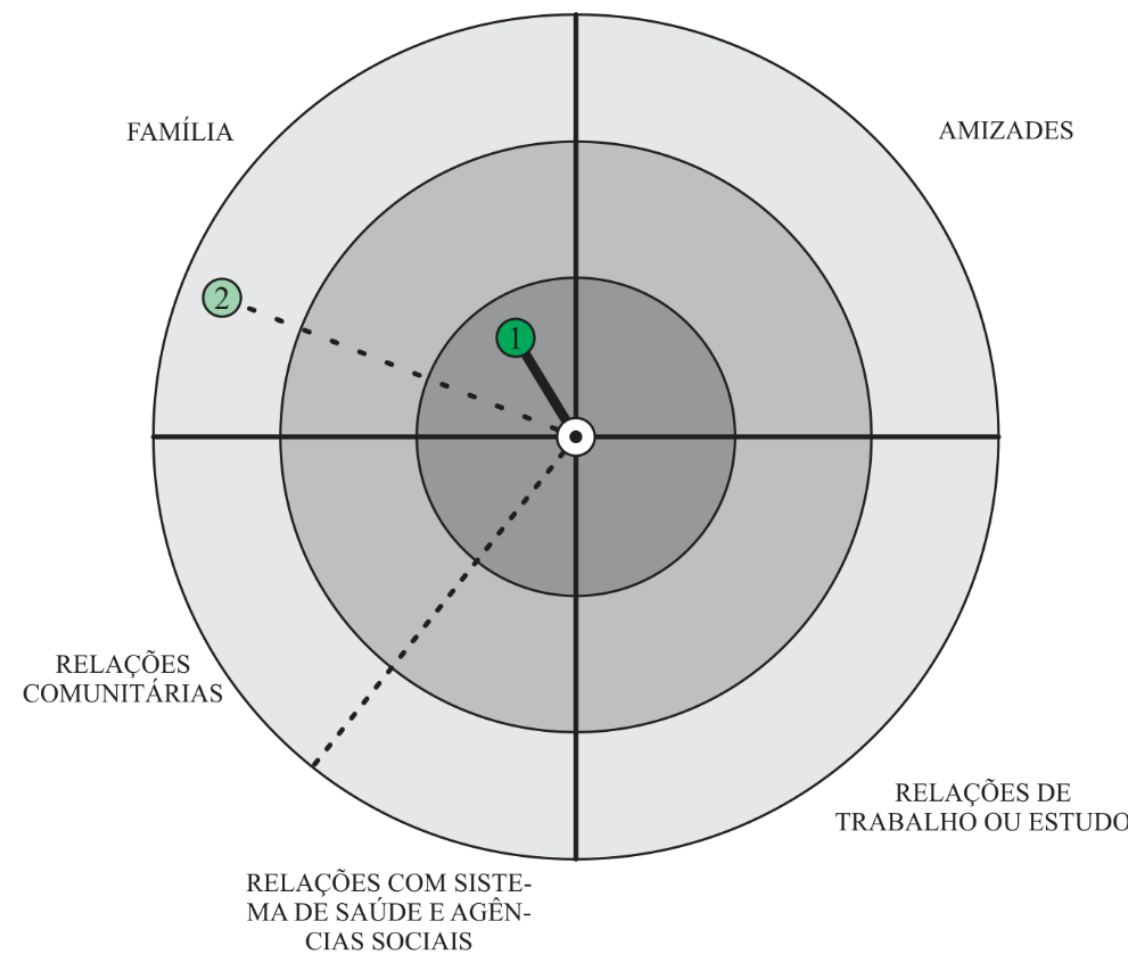

LEGENDA

- Adolescente

(1) Mãe

(2) Pai

Vínculo Significativo

- - Vínculo Fragilizado
Relações íntimas

(família e grupo significativo)

Relações sociais

(com contato pessoal)

Conhecidos

(relações ocasionais distantes)

Figura 28 - Mapa de rede social do adolescente em LA - Vergonhoso, 15 anos 
ANEXO A

\section{Aprovação do Comitê de ética (CEP) em pesquisa da EERP-USP}
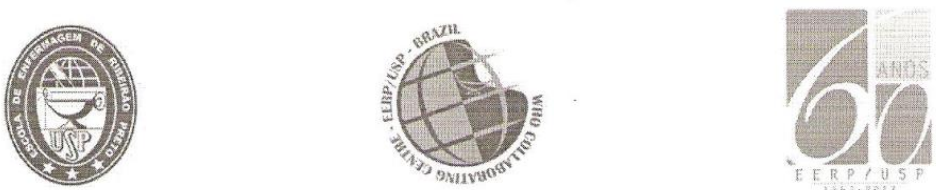

ESCOLA DE ENFERMAGEM DE RIBEIRÄO PRETO DA UNIVERSIDADE DE SÃO PAULO

Centro Colaborador da Organização Mundial da Saúde para o Desenvolvimento da Pesquisa em Enfermagem Avenida Bandeirantes 3900 - Piberzo Proto - Sa Pavo - Brasil - CEP 14040-902 - Fone: 5516 3602.3382 - 55163602.3381 - Fax: 55163602.0518 www.eerp.usp.br - eerp@edu.usp.br

COMITÊ DE ÉTICA EM PESQUISA DA EERP/USP

Of.CEP-EERP/USP - 163/2013

Ribeirão Preto, 24 de junho de 2013

Prezada Senhora,

Comunicamos que o projeto de pesquisa, abaixo especificado, foi analisado e considerado APROVADO AD REFERENDUM pelo Comitê de Ética em Pesquisa da Escola de Enfermagem de Ribeirão Preto da Universidade de São Paulo, em 24 de junho de 2013.

\section{Protocolo CAAE: 12756713.4.0000.5393}

Projeto: Rede social: contribuições a adolescentes em liberdade assistida.

Pesquisadores: Marta Angélica lossi Silva

Marilene Rivany Nunes

Em atendimento à Resolução 196/96, deverá ser encaminhado ao CEP o relatório final da pesquisa e a publicação de seus resultados, para acompanhamento, bem como comunicada qualquer intercorrência ou a sua interrupção.

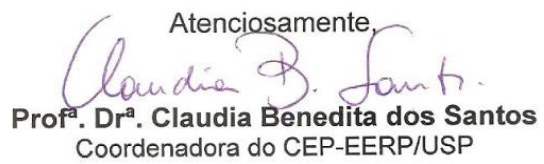

IIma. Sra.

Profa. Dra. Marta Angélica lossi Silva

Departamento de Enfermagem Materno-Infantil e Saúde Pública

Escola de Enfermagem de Ribeirão Preto - USP 


\section{ANEXO B}

Parecer da revisora de língua portuguesa

DECLARAÇÃo

Eu, Mara de Deus Patrício, RG 2.381.599, graduada em Letras pelo Centro Universitário de Patos de Minas - UNIPAM e pós-graduada em Literatura Brasileira e Língua Portuguesa - UNIPAM, declaro ter realizado a análise e correção ortográfica e gramatical da Tese intitulada: "Rede social de adolescente em liberdade assistida: um estudo exploratório" da aluna Marilene Rivany Nunes, do curso de Doutor em Ciências, do Programa de Pós-Graduação em Enfermagem em Saúde Pública.

Por ser verdade firmo o presente.

Patos de Minas, 21 de março de 2015.

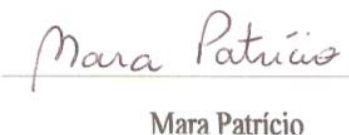

Mara Patrício 